\title{
Reconstituição do traçado da "estrada dos Goiases" no trecho da atual mancha urbana de Campinas'
}

Pedro Francisco Rossetto ${ }^{2}$

RESUMO: $\bigcirc$ artigo trata de reconstituir o traçado do trecho da estrada dos Goiases (rota de penetração bandeirista, aberta em 1722) na região da atual mancha urbana da cidade de Campinas através da análise de fotografias aéreas datadas de junho de 1940. O resultado - o traçado que corresponde às evidências coligidas - concorda com o traçado esquemático apresentado pelo historiador Celso Maria de Mello Pupo (PUPO, 1969), discordando de tradição divergente e presentemente dominante, no que concerne a trabalhos acadêmicos relativos à história de Campinas, também comentada. A reconstituição desse trecho do traçado desta antiga estrada a que Campinas deve suas origens impõe-se como passo inicial para a compreensão da posterior evolução do traçado urbano da cidade.

PALAVRAS-CHAVE: Campinas. Estrada dos Goiases. Fotografia Aérea. Foto-interpretação.

ABSTRACT: This paper seeks to retrace a stretch of "Estrada dos Goiases" (an old trail opened in 1722 by frontiersmen moving west) over the urban area of present-day Campinas, basically through an analysis of aerial photographs dated June 1940. The result - i.e. the outline ensuing from the evidence gathered - coincides with the sketch presented by historian Celso Maria de Mello Pupo (PUPO, 1969), but it diverges from a traditional and prevailing opinion found in academic works concerning the history of this city, which is also discussed in the paper. Retracing the said stretch of the old route, to which Campinas owes its origins, is an important first step towards a clearer understanding of the subsequent development of the city's urban contour.

KEYWORDS: Campinas/São Paulo. "Estrada dos Goiases". Aerial Photography. Photographic Interpretation.

Foi a partir da abertura, em 1722, do caminho de penetração bandeirista conhecido por "estrada dos Goiases", ligando São Paulo às minas dos Goiases, que teve início o povoamento da região do atual município de
1. Este artigo é uma versão ampliada de trabalho originalmente entregue à disciplina AUH 5853, do curso de pós-graduação da Faculdade de Arquitetura e Urbanismo da Universida de de São Paulo, sob orientação do prof. Dr. Gustavo Neves da Rocha Filho. Agradeço ao prof. Dr. Gustavo Neves pela oportunidade deste estudo, bem como pelo contato com o emprego de fotografias aéreas como recurso de pesquisa, cujas potencialidades talvez não teria, de outra maneira, vindo a suspeitar.

2.Mestre pela FAU-USP,Bolsista do CNPq entre 2004 e 2006. E-mail: <pedroros setto@hotmail.com>. 
3. Uma pesquisa criteriosa nos livros de atas da Câmara municipal permitiria uma tal reconstituição da evolução do traçado da cidade de Campi nas, desde a fundação da Freguesia, até circa 1878 Do que se tem publicado, podemos apontar a reconstituição apresentada por Celso Maria de Melo Pupo (1969, p. 114) para a vila no ano de 1840 . São também de grande interesse os dois documentos transcritos - uma parte de um manuscrito de cidadão nascido em 1835 , intitulado Notas so bre Campinas, registrando aspectos urbanos da Campinas de meados do século XIX; e o relatório apresentado à Câmara Municipal, na sessão de 6 de Setembro de 1848 , por comissão especial encar regada de, pela primeira vez, dar nomes aos logradouros da cidade - publicados por Rafael Duarte ( 1904); consultamos o livro de atas na data referida por Rafael Duarte, havendo menção ao "relatório incluso", que entre tanto lá não se encontra. Restam, entretanto, mui tas questões a partir da confrontação dessas fontes, tornando-se indispensável uma pesquisa mais alongada. Aos que estudam Campinas e tenham lido o livro de Amaral Lapa (1996), pode-se, contudo, desde já, apontar que os termos do pedido dos moradores, de 1864, para abertura de uma dada rua - pedido que reputa "redigido de maneira confusa" e em torno do qual se detém entre as p. 44 e 47 -, tor nam-se claros a partir das indicações do referido relatório de 1848, transcrito por Duarte (e com apoio em Goulart, 1983 , p. 52). Quanto a ser a planta de 1878 a mais antiga que se conhece, vale apontar que Duarte (1904) fala numa "planta
Campinas, e a origem da cidade liga-se à localização do "pouso das Campinas", nessa estrada. O presente trabalho trata de reconstituir o traçado da "estrada dos Goiases", no território atualmente ocupado pela mancha urbana de Campinas, através de foto-interpretação realizada sobre levantamento aéreo datado de Junho de 1940, interpretação informada por revisão sistemática da bibliografia existente sobre o tema e com recurso circunstancial a fontes primárias, para melhor fundamentação de aspectos em que a citada bibliografia diverge.

O traçado aqui apresentado (ao final), como resultado das pesquisas, concorda com o traçado esquemático apresentado por Celso Maria de Mello Pupo (PUPO, 1969, p. 47), distanciando-se de proposição que aponta o vale do Proença (avenida Norte-Sul) como parte desse percurso, proposição essa que vai também comentada.

A reconstituição do traçado da antiga estrada dos Goiases na região da atual mancha urbana coloca-se como um primeiro passo, que seria necessário firmar, para uma reconstituição da evolução do traçado urbano da cidade de Campinas, anteriormente à primeira planta conhecida, de $1878^{3}$.

A estrada dos Goiases

A origem da cidade de Campinas vincula-se à abertura de uma nova rota bandeirante - o "caminho geral dos Goiases". Como se sabe, os paulistas descobriram as primeiras jazidas significativas de ouro no Brasil em fins do século $X V I I$, na região do rio das Velhas (no atual estado de Minas Gerais). A região foi logo alvo de intenso movimento migratório, havendo conflitos pela posse das minas, dos quais a "guerra dos Emboabas" (1708-1709), opondo paulistas e adventícios, é um marco. Estando em desvantagem nessas disputas - e em vista ainda do crescimento do controle pelo fisco e pela coroa -, os paulistas reencetaram a busca de novas minas, iniciando o povoamento da região do atual estado de Goiás.

A penetração em direção a Goiás teria sido feita, de início, "através dos sertões mineiros, varando-os os bandeirantes em direção a Paracatu, de onde passavam para Goiás, atravessando os rios Paraíba e Corumbá"4. Em 1721, entretanto, determina-se a abertura de uma nova rota. Por um lado, tratavase de evitar a passagem por território de jurisdição alheia, visło o território das Gerais ter sido desmembrado daquele da capitania de São Paulo em 1720; por outro, de incrementar a descoberta de minas, enviando Bartolomeu Bueno da Silva, o segundo Anhangüera, na busca de jazidas "que já uma vez visitara, contando apenas doze anos de idade, em companhia de seu pai, Bartolomeu Bueno da Silva, o primeiro Anhangüera" (CAMPOS JR., 1952, p. 6).

Luís Pedroso de Barros, paulista que se envolvera nos conflitos da região das Gerais e andava foragido, adiantou-se a abrir uma picada na rota pretendida, "mediante $\mathrm{o}$ indulto de suas culpas, uma comenda da ordem de Cristo e uma tença anual de 50\$000"s. Aberta a picada, a bandeira de 
Bartolomeu Bueno da Silva parte de São Paulo a 30 de junho de 1722, sendo bem-sucedida em sua missão - estava aberto o "caminho geral dos Goiases".

A Figura 1, detalhe de uma planta do último quartel do século XVIII, tem marcado o percurso em causa. Vê-se o modo como o caminho margeia e contorna a divisa com a nova capitania das Gerais, evitando penetrar naquele território.

A estrada dos Goiases e a região de Campinas.

Partindo de São Paulo, o "caminho geral dos Goiases", ou "estrada dos Goiases" seguia rumo geral Norte, margeando, a Leste, a encosta da serra da Mantiqueira, atravessando os atuais municípios de Jundiaí, Mogi-Guaçu, Casa Branca, e Franca, entre outros, até o atual município de Uberaba, de onde defletia a Oeste, atingindo a região das minas de Goiás ${ }^{6}$.

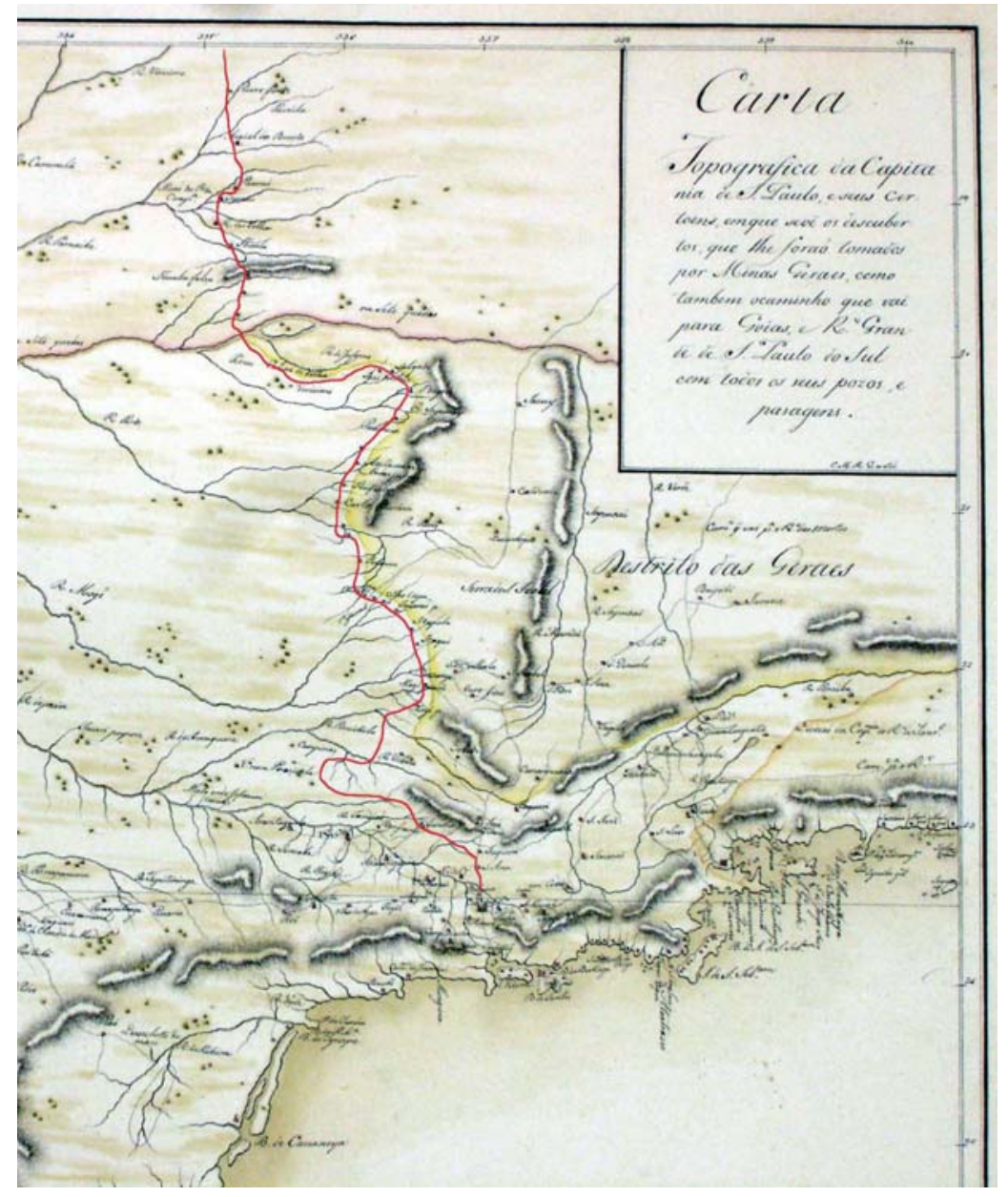

topográfica" que teria sido executada por Custódio Manoel Alves e, já àquele tempo (1904), "desde há muito desaparecida"; e que Bergó (1944), ainda em 1944,referia-se a uma "planta de $1843 "$.

4.Cf.Omar Simões Magro (CAMPOS JR., 1952, p.6).

5. Idem. Ibidem.

6. É o rumo geral que a estrada de ferro Mogiana
Figura 1 - Detalhe de "Carta Topografica da capitania de S. Paulo e seos certoens, emque sevê os descubertos [... ]como tambem o caminho que vai para Goias [...]", que destacamos em vermelho. Note-se como o caminho margeia a Serra da Mantiqueira e a divisa da então recém-criada capitania das Gerais, marcada no original em tom amarelo.C. H. R. Carta Topografica da Capitania de S. Paulo e seos certoens. [177?]. Bico de pena sobre papel. Coleção Pirajá da Silva, Mapoteca da Biblioteca Municipal Mário de Andrade, São Paulo. Reprodução do autor. 
viria a percorrer, a partir de 1875 . Essa é a rota seguida, em 1818, por Luís D'Alincourt, e por ele minuciosamente descrita em seu Relato de uma viagem do porto de Santos à cidade de Cuiabá (D'ALINCOURT, 1975), bem como, no sentido in verso, por Saint-Hilaire, que, depois de viajar a partir do Rio de Janeiro pela região das Gerais e de Goiás, ruma para São Paulo, em 1819 (SAINT HILAIRE, 1976). Foi ainda a rota trilhada, em 1865 , pela tropa do General Drago, rumo à Guerra do Paraguai, trajeto descrito pelo Visconde de Taunay, que fez parte da expedição, e editado por seu filho na década de 1920 (TAUNAY, s/d)

7.Até 1769 , as terras sob jurisdição de Jundiaí abrangiam todo o sertão, em direção das minas. Nesse ano, a freguesia de São José de Moji-Mirim é elevada a vila e desmem brado o respectivo território, fixando-se a divisa no rio Atibaia.

8. Informação devida a re lato de membro da expedição do segundo Anhanguera (BRAGA, 1883), e reproduzida por diversos autores da historiografia campineira (OCTAVIO, 1922, p. 11; CAMPOS JR, 1952,p.6;SANTOS, 1998 p. 77).

9.Veja-se entre outros $\mathrm{Pu}$ po (1969,p.11-12).As tropas de mulas somente se tornam usuais a partir de meados do séc. XVIII. A bandeira de 1722 não contava com muares.

10. Carta de sesmaria publicada em São Paulo (1921, p. 428). O mesmo documento está parcialmente transcrito em Campos Jr. (1952, p. 7), e em Santos Filho (1969).
De São Paulo até Jundiaí (vila desde 1655), a região era de campos. Junto de Jundiaí tinha início uma densa floresta, que se estendia até pouco antes da região de Mogi, onde, recomeçando os campos, havia, já na época da abertura da estrada dos Goiases, um conjunto disperso de casas, ou "arraial". Como tudo, então, pertencia ao termo da vila de Jundiaíi, essa extensão de mata cerrada era o "mato grosso de Jundiaí".

Sabe-se que, nos primeiros tempos da estrada, levavam-se quatro dias para atravessar essa região do "mato grosso de Jundiaí" ${ }^{\text {. }}$. A floresta cerrada não favorecia o crescimento de vegetação rasteira e pastagens, necessárias à alimentação das tropas de mulas ao longo desses dias de travessia. De importância estratégica seria, portanto, um conjunto de pequenas clareiras, ou "campinhos", existentes em meio ao mato grosso a certa altura do trajeto. Eram as "campinas do mato grosso de Jundiaí". É nas proximidades desses "campinhos", ou clareiras, que viria a se formar um pequeno núcleo - e a futura cidade de Campinas?.

Da existência dos campinhos, e de que teriam sido três, há evidência em documento de época, o de concessão da primeira sesmaria na região a Antônio da Cunha Abreu. Nessa carta de sesmaria, de novembro de 1728, lêse que as terras, pedidas e concedidas, eram "no caminho das minas novas de goiases, no logar a que chamam os Campinhos", estando os ditos campinhos "em distância de quatro legoas, com pouca diferença", do ponto de transcurso do rio Atibaia; e, finalmente, que "os ditos campinhos eram três, sendo o maior o do meio". Tal sesmaria seria de uma légua de terras em quadra, "fazendo pião no campinho maior" ${ }^{\prime \prime}$.

No ponto em que se encontravam os tais campinhos, em meio ao mato grosso, formou-se pouso que teria sido o primeiro da nova estrada ", conhecido como pouso dos campinhos, ou das campinas. Sabe-se que o local desse pouso não corresponde àquele em que veio a ser construída a matriz da nova "freguesia de Nossa Senhora da Conceição das Campinas do Mato Grosso", em 1774, matriz junto da qual se desenvolveria a vila (1797) e cidade (1842) de Campinas. $O$ pouso se encontrava na região que seria conhecida por "Campinas Velhas"12 desde, pelo menos, o início do século XIX. A matriz em 1774 uma capela provisória, sete anos depois uma igreja de taipa - foi erguida junto da atual praça Bento Quirino, local de um dos três campinhos ${ }^{13}$, a Oeste do vale do Tanquinho e do curso da primitiva estrada ${ }^{14}$.

Nota-se que as plantas setecentistas das Figuras 1 e 2 dão o traçado do caminho dos Goiases como passando à distância do ícone que representa a freguesia de Campinas, num testemunho impressionista de que a matriz fora construída afastada da estrada.

A bibliografia aponta a existência de derivações do caminho, ou estrada, abertas ao longo do seu primeiro decênio de existência (1722-1732). A disputa pela exploração de vendas e pousos teria levado à seguida abertura de novos atalhos, expediente que teria sido particularmente recorrente na região do atual município de Campinas. Em 1732, por exemplo, "Alexandre Simões Vieira, morador da Vila de Jundiaí, abre por conta própria uma nova comunicação entre aquela vila e a região dos Campinhos" ${ }^{15}$ e passa a explorar a venda de gêneros aos tropeiros, fazendo "uma roça de três alqueires de plantação no meio 


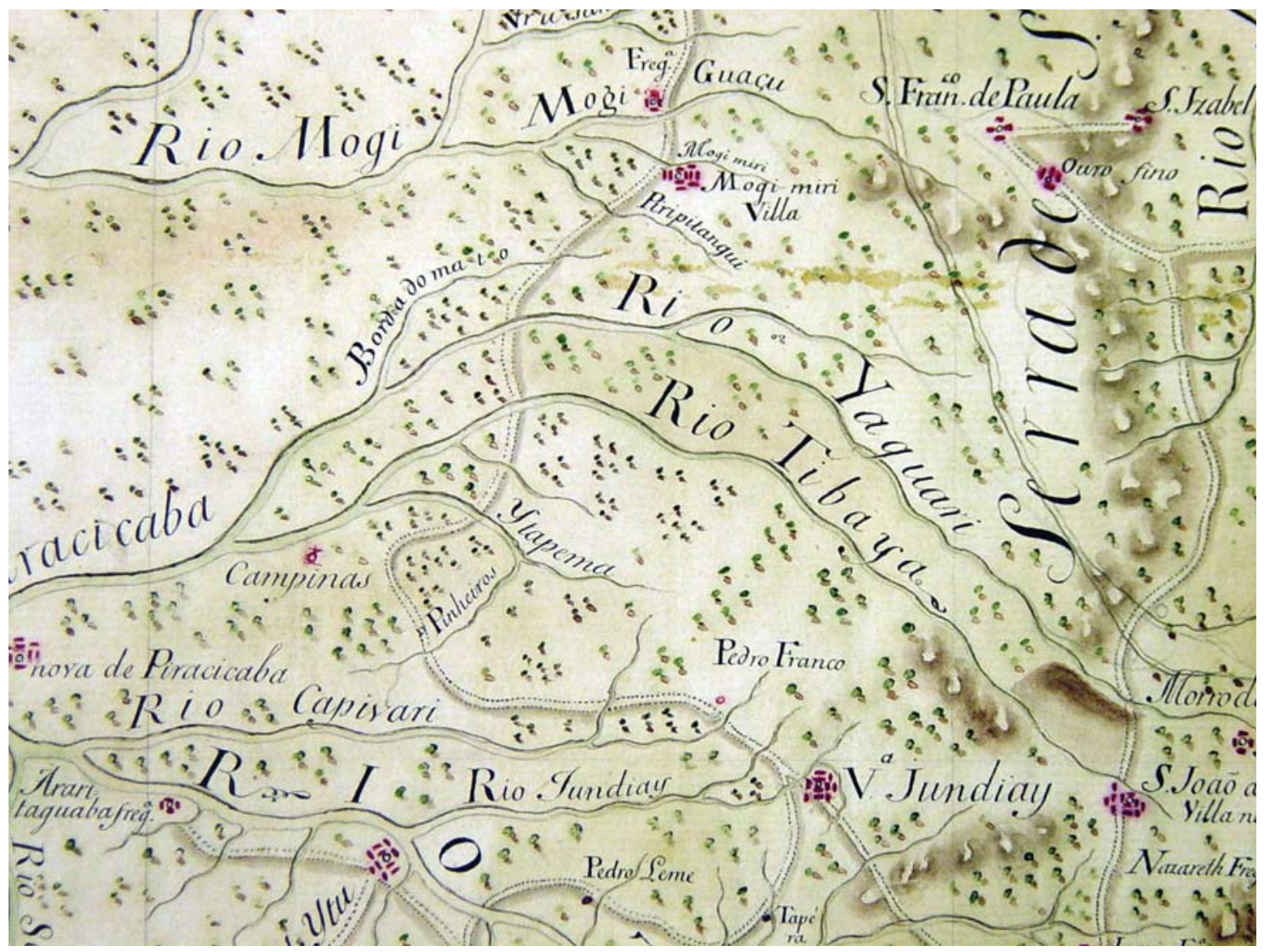

Figura 2 - Embora o povoamento do futuro município de Campinas tenha se dado a partir da abertura da estrada dos Goiases, a capela, marco de fundação da futura cidade, não foi construída junto da estrada ou do pouso das campinas, mas a cerca de 700 metros dela. No detalhe acima, de mapa cuja data presumida - 1774 - coincide com o ano da ereção em freguesia do bairro das campinas e de construção da respectiva matriz, vêse como Jundiaí e Mogi estão representadas por um ajuntamento de quadras, à beira do caminho, ao passo que o pequeno círculo com uma cruz, que representa a freguesia das Campinas do Mato Grosso, está dele afastado. Carta de parte da diocese paulopolitana. [1774?]. Detalhe. Bico de pena sobre papel. Coleção Pirajá da Silva. Acervo da Mapoteca da Biblioteca Mário de Andrade. Reprodução do autor.

do dito caminho em um ribeirão chamado Pinheiro"16 (na atual cidade de Valinhos) ${ }^{17}$. Entretanto, a motivação para esses expedientes deixa de existir naquele mesmo ano de 1732, quando Antônio da Cunha Abreu - homem influente, e que, aliás, nunca habitou a sesmaria que lhe fora concedida, interessando-se apenas na exploração dos pousos, nessa como em outras terras de sua propriedade - consegue do capitão-general Antônio Luís de Távora uma resolução determinando que, caso alterados os trajetos da estrada, o referido donatário teria automaticamente preferência sobre as terras às margens dos novos trajetos ${ }^{18}$.

Posteriormente à ereção do bairro em Freguesia - cuja matriz, como dito, não ficava à beira do caminho - e com o desenvolvimento do povoado ao redor da matriz, o trajeto da estrada é atraído para junto desse novo núcleo, deixando de passar pelo antigo pouso para fazer-se, ao invés, nesse mesmo

11. Cf. Campos Jr. (1952, p. 8), referindo-se a obra deAntônio Ferreira Cezarino Jr., Barreto Leme, sua vida, suas realizações.

12. “Já em 1804 chamavase Campinas-Velhas ao local de início do povoado" (OCTAVIO, 1907, p.29).

13. Como concordam os autores consultados e como veremos adiante. 
14. A bibliografia localiza a capela num dos extre mos da praça, onde hoje se encontra o monumento a Carlos Gomes; em 1781, a igreja definitiva, de taipa, é erguida no extremo oposto. Ampliada em diferentes ocasiões, foi demolida somente em 1929, dando lugar à atual Igreja do Carmo (PUPO, 1969, p. 42-44, 104)

15. Antônio Ferreira Cezarino Jr., Barreto Leme, sua vida, suas realizacões (apud CAMPOS JR. 1952, p.8)

16. Idem. Ibidem trecho, através do povoado, pela futura rua Direita, atual Barão de Jaguara. Esse novo trajeto é o acusado por d'Alincourt já em $1818^{19}$, e mais tarde pelo barão de Taunay ${ }^{20}$.

Há, na bibliografia, proposições divergentes quanto ao traçado que nos interessa - aquele existente por volta de 1774 e que, segundo as indicações disponíveis, estaria consolidado desde 1732. A reconstituição que apresentamos, feita a partir de foto-interpretação de imagens aéreas datadas de junho de 1940, concorda com o desenho esquemático desse trajeto, apresentado pelo historiador Celso Maria de Mello Pupo em seu livro Campinas, seu berço e juventude (PUPO, 1969, p. 43), que reproduzimos aqui (Figura 3). Pupo não expõe no texto as justificavas do traçado que apresenta, referindo-se apenas genericamente a "indicações históricas".

Esse esquema não coincide com alguns outros, propostos em outros trabalhos, dentre os quais, pela sua recente influência, destaca-se o de Costa Santos (1998), como veremos mais à frente.

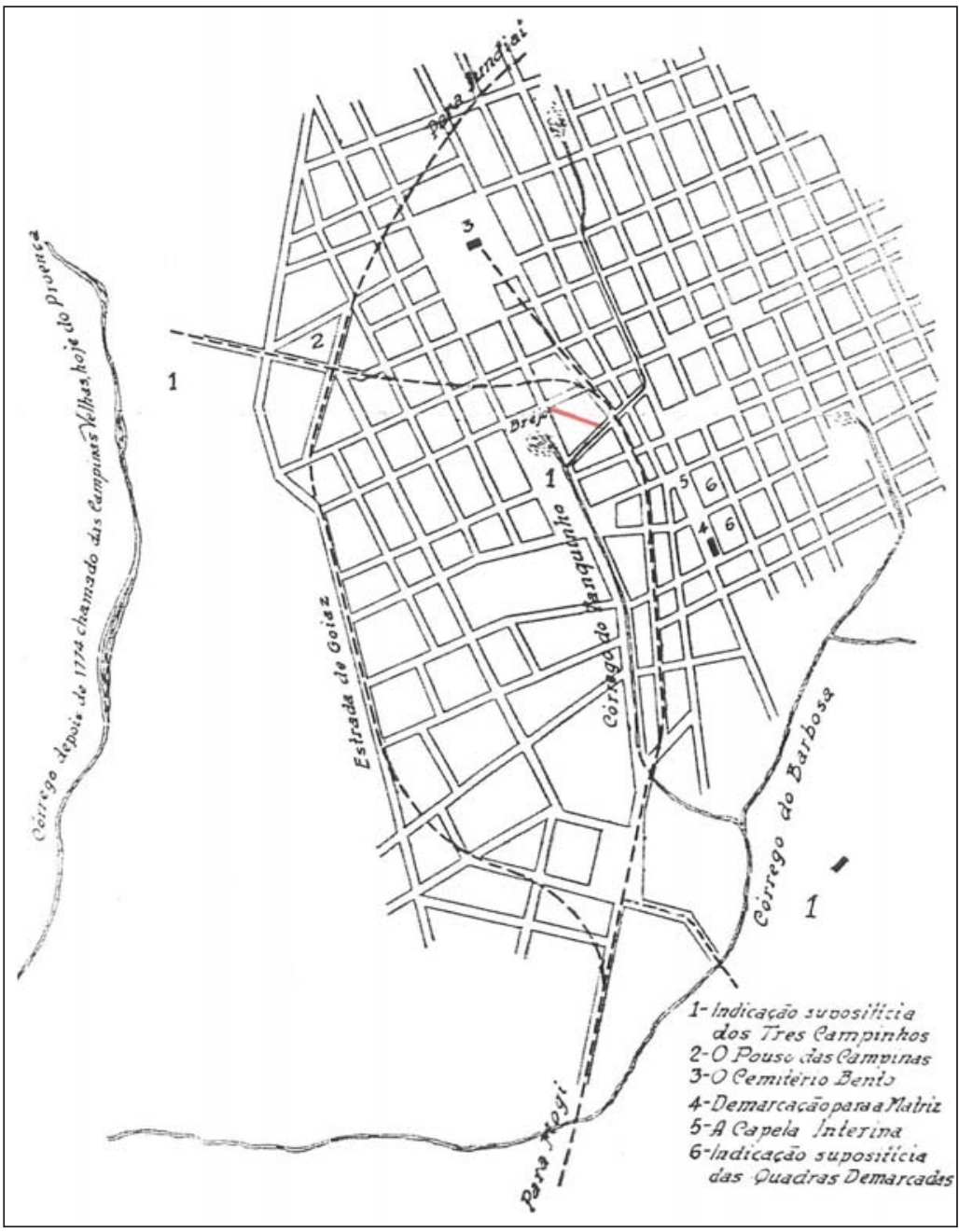

146
Figura 3 - Traçado da "Estrada de Goiaz" là esquerda) e "caminhos locais", segundo Celso Maria de Mello Pupo lo norte está para baixo). $\bigcirc$ esquema geral do traçado proposto por Pupo para a estrada dos Goiases, nesse trecho central da cidade, é coerente com os indícios que obtivemos pela foto-interpretação. É curioso que Pupo tenha feito desviar do "beco do Rodovalho" (destacado em vermelho) o trajeto de ligação do pouso das Campinas (2, na figura) com o local da sede interina da freguesia (5, na figura). Celso Maria de Mello Pupo, Campinas em 1774 sobre Campinas de hoje. Croqui (PUPO, 1969, p. 47). 
Ao tempo da publicação de Campinas, seu berço e juventude (1969), Celso Maria de Mello Pupo, nascido com o século XX'12, acumulava longos anos de pesquisas sobre a história da cidade. De índice de sua erudição a respeito da história local serve o fato de ter sido ele o responsável pela determinação da própria data hoje aceita como de fundação da cidade, contra uso divergente, em processo submetido ao arbitramento do Instituto Histórico e Geográfico de São Paulo22. Ou o fato de ter indicado o local do primitivo "campo santo" (cemitério) do então bairro das Campinas, até então dado por desconhecido ${ }^{23}$.

Essas observações servem para evidenciar que, na reconstituição por ele oferecida, importa o conhecimento, extensamente acumulado, de documentação primária, eclesiástica e civil, relativa aos primórdios da ocupação local - registros anteriores à ereção em freguesia, buscados em arquivos de Jundiaí, Itu, Taubaté; os "livros de tombo" da freguesia, desde 1774; as atas da Câmara, desde 1797; e outros ${ }^{24}$.

O método da reconstituição a que aqui procedemos é diverso. Se bem tenhamos recorrido pontualmente à documentação primária e realizado levantamento sistemático da documentação secundária, essas fontes servem de parâmetro à investigação, baseada notadamente na conformação do relevo e na existência de marcas passíveis de identificação numa "leitura" de imagens de levantamento aéreo (fotografias aéreas), processo tecnicamente conhecido como "foto-interpretação".

Importa é notar essa coincidência de resultados obtidos por metodologias diversas. Que a reconstituição a que procedemos, baseada em método diverso do empregado por Celso Maria de Mello Pupo, resulte em um traçado compatível com aquele por ele apresentado, serve, por assim dizer, de contraprova da validade daquela sua proposição esquemática. E vice-versa: o fato de o croquis de Celso Maria de Mello Pupo - titular de notória erudição no que respeita à documentação guardada nos arquivos, eclesiásticos e civis, da cidade -, conferir com o traçado obtido no presente trabalho dá força aos métodos e aos resultados aqui obtidos.

Entretanto, enquanto Celso Maria de Mello Pupo (1969) localiza a estrada em terreno elevado, entre os vales do Tanquinho e do Proença, consolidouse tradição historiográfica em contrário, afirmando ser a localização do pouso, e conseqüentemente de pelo menos parte da estrada, na baixada do vale do Proença. Na reconstituição apresentada por Costa Santos (1 998), todo o trajeto, no trecho que aqui nos interessa, segue pelo vale do Proença latual avenida Norte-Sul). Esta última proposição é merecedora de especial crédito e destaque: é o único caso da bibliografia em que o traçado proposto vem justificado no texto; é proposta resultante de trabalho especificamente voltado para tal reconstituição, com ampla base documental, no qual esteve envolvida equipe de pesquisadores ${ }^{25}$. Afora Pupo (1969), é o único trabalho a ter sido publicado em livro ${ }^{26}$ e vem exercendo particular influência ${ }^{27}$.

O entendimento de que o pouso das campinas se localizasse, não no atual cruzamento da avenida Moraes Sales com rua ltu, em cota elevadacomo quer Pupo e como as evidências recolhidas no presente trabalho sustentam
17. "Segundo o professor Mário Pires, em seu livro Valinbos: Tempo e Espaço, a localização deste chamado Pouso de Pinheiros provavelmente é o atual bairro Capuava, o qual o historiador considera a "célula mater» de Valinhos". Em Do pouso dos bandeirantes à capital do figo roxo. Disponível em:<http:// www. valinhos.sp.gov.br>.Acesso em 28.jul.2004.

18. Sobre a região de Campinas ter sido aquela em que mais houve disputa pela exploração de pousos e vendas (e conseqüentemente maior número de variantes no caminho), vide Campos Jr. (1952, p. 7), que nesse ponto refere Antônio Ferreira Cezarino Jr., op. cit.; sobre Antônio da Cunha Abreu não ter sido povoador da região dos Campinhos, de que foi o primeiro sesmeiro, vide Pupo, 1969; sobre a resolução do governador da capitania em salvaguarda dos interesses de Antônio Cunha de Abreu, cf. Campos Jr. (1952, p. 8).

19. D'Alincourt (1975, p. 51, 54).

20.Taunay ([1928?],p.19).

21. Pupo nasceu no ano de 1900. Faleceu em 2003, em Campinas, onde residia desde 1914 .

22.Ver Pupo (1969, p. 11 49), especialmente p. 15 nota 12 e p. 44 nota 56. O processo é historiado no livreto de Benedito Barbosa Pupo, À margem da bistória de Campinas... (PUPO, 1973).

23. Cf. Lorette (2003, p. 51-52). A dedução da localização encontra-se em Pupo (1969, p. 23).

24. Documentos citados em Pupo (1969).

25. O trabalho de reconstituição contou com a co- 
laboração de equipe da Embrapa-NMA-Campinas. Santos (1998), p. 68 nota 109.

26.A tese de Costa Santos (1998) foi publicada em livro pela editora da Unicamp, em 2002, sob o título Campinas: das origens ao futuro.

27. Lorette (2003, p. 52), por exemplo, reproduz de Santos (1998) as afirmações quanto à localização do pouso das campinas $\mathrm{e}$ do traçado da estrada.

28. Nesse caso, refutação somente possível por Santos (1998) registrar em texto as ditas justificativas, fato único, como referido, ao qual prestamos nosso reconhecimento.
-, mas no ponto correspondente a esse na baixada do vale, é hoje predominante. O levantamento sistemático das fontes secundárias permite afirmar, por um lado, que não são expostas as bases de tal entendimento, e concluir, por outro lado, que essa tradição tem origem em leitura possível, mas não necessariamente correta, de texto de 1922, dada em trabalho de 1944 e, desde então, reproduzida em diversos outros trabalhos.

A proposta de Santos (1998) para o trajeto do caminho apóia-se nesse entendimento a respeito da localização do pouso, bem como no pressuposto de que dada propriedade, citada no documento que the serve de guia, abrisse frente para o vale, podendo-se afirmar documentadamente que a situação da frente de dita propriedade é entretanto outra.

A investigação leva, portanto, a refutar a proposição de que o pouso se localizasse no vale, bem como a de que o caminho trilhasse pelo mesmo vale, não apenas por não concordarem com as evidências colhidas na fotointerpretação mas também como resultado, no primeiro caso, da perseguição às bases historiográficas dessa afirmação, e, no segundo, pela análise das justificativas dadas em texto pelo autor ${ }^{28}$.

Consideração preliminar: hipótese de a estrada dos Goiases ter rumado pelo vale do Proença

Preliminarmente, observe-se que a hipótese de que o caminho dos Goiases, na região da atual mancha urbana de Campinas, tivesse rumado pelo vale do Proença tem contra si o próprio fato de ser proposto um percurso por fundo de vale. Contrariamente a um senso difundido, as bandeiras não se aproveitavam do curso dos rios como meio de penetração. Pelo contrário, evitavam em regra os trajetos por fundo de vale. No caso particular que nos interessa, a proposição de que o caminho tivesse seguido pelo vale do Proença torna-se tanto mais improvável quando se tenha em conta as dificuldades de cavaleiros e pedestres ou, ainda, de tropas de muares, em tomar rumo por uma várzea inundável, mais precisamente um brejo, como é o caso do citado vale.

Em 1941, o historiador Sérgio Buarque de Holanda justifica o tema da palestra que profere, sobre "as monções", no "curso de bandeirologia" promovido pelo governo do estado de São Paulo, por serem tanto as bandeiras, fenômeno notadamente do século XVII, quanto as monções, do século XVIII, igualmente movimentos de penetração, responsáveis pelo alargamento das fronteiras dos domínios portugueses na América, num exemplo comum do "espírito desbravador" a que o curso, e a época, rendiam homenagem. Não obstante, traça entre ambos os fenômenos uma clara linha divisória: "Estas [monções] começaram a aparecer quando aquelas [bandeiras] já entravam em declínio" (HOLANDA, 1941, p. 127). "Naquela [bandeira] os rios constituem efetivamente obstáculos à marcha e as embarcações, em geral simples canoas de casca ou 
toscas jangadas, são apenas recurso ocasional do sertanista, utilizável onde a marcha a pé se tornou impossivel." (ldem, p. 129)

Holanda refere-se expressamente ao caso que nos interessa, da "jornada aos goiases do segundo Anhanguera", como exemplo de bandeira: "uma das grandes empresas bandeirantes, talvez a última grande empresa bandeirante" (ldem, p. 128).

Em livro publicado poucos anos depois e dedicado ao mesmo tema, Holanda insiste na diferenciação, reiterando ainda a colocação da estrada dos Goiases como um caminho terrestre:

Para as pilhagens do Guairá, poucas vezes se recorreu ao Tietê e ao Paraná. A via predileta era a terrestre, e o Paranapanema só ocasionalmente serviu para a navegação. Nas Minas Gerais, transposta a garganta do Embaú, os rios corriam quase sempre em sentido transversal ao das estradas. Por vezes, o mesmo curso d'água chegava a interpor-se em diversos pontos à passagem do caminhante. Outro tanto sucedia com relação ao caminho das minas dos Goiases, que corresponde grosso modo ao traçado da atual Estrada de Ferro Mogiana ${ }^{29}$ [grifo nosso].

Em apoio à mesma constatação, Holanda (2000, p. 21 ) cita ainda um trecho de livro de 1924, de Alfredo Ellis Jr., a quem "cabe, aparentemente, o mérito de ter sido o primeiro a mostrar quanto é ilusória a crença de que as vias fluviais tiveram uma ação decisiva sobre esse movimento [das bandeiras]".

Diz Ellis Jr.:

Outro grande erro, do qual não têm escapado mesmo muitos historiadores de certo renome, consiste na suposição de que o movimento expansionista das bandeiras se deu pelas vias fluviais. O Tietê, o velho Anhembi, que à primeira vista parece ter sido o grande caudal que determinou o bandeirismo, foi desconhecido de grande parte do movimento ${ }^{30}$.

"caminho dos Goiases", exemplo (tardio) de via de penetração bandeirista, é, portanto, um caminho eminentemente terrestre, não fluvial. Os mapas reproduzidos nas Figuras 1 e 2 deixam claro, de resto, como o caminho atravessa sucessivamente diversos rios, sempre transversalmente aos respectivos vales, sem nunca acompanhar qualquer desses vales.

Pode-se, ainda, invocar o relato legado por membro da bandeira de 1722, que, ao longo de todo o percurso, não se refere nenhuma vez a fatura ou uso de canoas. Somente quando deserta da expedição é que o faz "derrotando os rios" correnteza abaixo, em canoas que então constrói ${ }^{31}$.

Do trecho que nos interessa, o relato limita-se a informar que the tomara quatro dias a travessia do "mato grosso", entre Jundiaí e Mogi:

Sahi da cidade de São Paulo a três de julho de 1722 em companhia do Capitão Bartolomeu Bueno da Silva, Anhanguera de alcunha. Passado o rio Theatê fomos pousar neste dia junto do matto do Jundiay, quatro léguas distante da cidade de S. Paulo. Na marcha seguinte entramos no mato e gastamos nele quatro dias. Saídos do mato passamos o rio Mogi [... $]^{32}$.
29. Holanda (2000, p. 21) De original publicado em 1945.

30.Alfredo Ellis Jr., O bandeirismo paulista e o recuo do meridiano (Apud HOLANDA, 2000, p. 21, nota 3).

31. Indo dar em missão jesuítica doAmazonas, donde é levado à cidade de Belém. Relato de José Peixoto da Silva Braga (BRAGA, 1883; original da terceira década do século XVIII). O mesmo relato é citado por Santos (1998) a partir de transcrição no undécimo tomo da História geral das bandeiras paulistas, de Taunay.

32. Cf. Braga (1883,p.62). A demora de quatro dias em meio ao "mato grosso" foi, como visto, referida por Pupo (1969). Antes dele, Octavio (1922) já referira o fato. Esse mesmo trecho encontrase transcrito também por Santos (1998, p. 77). 
33. Cf. Holanda (2000, p. 26).

34. Segundo Holanda (1941;2000) as bandeiras rumavam sobretudo a pé. A bandeira do segundo Anhanguera, contando com alguns cavalos, foi caso de exceção (HOLANDA, 2000,p.167).Um dos poucos cavaleiros era o alferes José Peixoto da Silva Braga (BRAGA, 1883), outros seguiam a pé.

35. Cf. Duarte (1905, p 27).

36. CAMPINAS, Câmara Municipal. Livro de Atas, 1881-1883. Sessão de 1 de agosto de 1881 .
É possível determinar, com segurança, que no trecho de nosso interesse, a exemplo do que se observa no caminho como um todo, o percurso era terrestre, ou seja, sem uso de canoas. Canoas, jangadas, "pelotas" eram feitos na ocasião, para transposição de rios em que se tornassem necessários, ou seja, para casos em que, pela profundidade ou correnteza, os rios não permitissem a travessia a pé, a cavalo ou a nado (HOLANDA, 1941; HOLANDA, 2000). No trecho da atual mancha urbana de Campinas o percurso não atravessa rios desse tipo. Santos (1998), como referido, faz passar a trilha bandeirante pelo vale do Proença. Não simplesmente atravessando o vale, mas seguindo por ele, e pelo rio; entretanto num trecho restrito, compreendido todo ele dentro do atual município de Campinas. Uma vez que a expedição não transportava embarcações, seria necessário admitir que elas tivessem sido feitas na ocasião para a navegação desse pequeno trecho. $\bigcirc$ alferes José Peixoło da Silva Braga quando, como referido, deserta da expedição e principia, somente então, a tomar curso pelos rios, refere ter tomado 12 dias na fatura de uma das ditas canoas - muito mais que os quatro dias que tomava o transcurso pelo "mato grosso", entre Jundiaí e Mogi.

Admitindo-se que a estrada dos Goiases na região da atual mancha urbana de Campinas tivesse rumado pelo vale do Proença, e excluída a possibilidade de que o percurso tivesse sido efetuado nesse trecho com embarcações, restaria a possibilidade de que o dito vale houvesse sido percorrido a pé (e a cavalo) $)^{34}$. É preciso lembrar que o curso em causa não constitui um ribeirão correndo em um vale de formação rochosa, mas uma várzea inundável, brejo, lodaçal. Brejo que vem representado como tal em plantas de 1916 e 1929 (Figura 4), anteriores à abertura da avenida Norte-Sul e às competentes obras de drenagem. Aparecendo ainda em romance histórico publicado em 1905, quando o narrador assim descreve o modo de se apanhar uma "inflamação das parótidas", a que chama "caxumba": "basta tentar a seguinte experiencia: [...] em dias de chuvisqueiro miúdo e persistente, marchar no calcante até as Campinas Velhas. Lá chegando, metter-se pelo brejo adentro, com lama até os joelhos $[\ldots]^{\prime \prime 35}$.

Vale ainda observar que, em 1881 , cidadãos "moradores do bairro do Atibaia" pediam "providências sobre a aguada denominada Campinas Velhas, junto a chácara do cidadão Elisiário Ferreira, cujo alagamento está vedando a passagem de troles e até de cavalleiros, por falta de váo, passando estes com dificuldade" ${ }^{36}$. Ou seja, o transcurso do vale do Proença, na altura do atual viaduto do Laurão, cruzamento das avenidas Moraes Sales e NorteSul, para aqueles que se utilizavam da estrada de ligação de Campinas a Souzas (então "bairro do Atibaia"), era dificultoso ainda em fins do século XIX, mesmo para homens a cavalo, devido ao "alagamento" da aguada ali localizada. Se a travessia do vale, em sentido transversal, oferecia tais embaraços, que dizer de um percurso que rumasse pelo mesmo vale, longitudinalmente, com alguns poucos cavaleiros e uma maioria de pedestres? 
O pouso das campinas localizava-se em fundo de vale: investigação das origens da afirmação e refutação dos pressupostos de Santos (1998).

Os fatos arrolados no item anterior são de sorte a tornar, em princípio, improvável a hipótese de que a estrada dos Goiases, na região da atual mancha urbana de Campinas, tivesse rumado pelo vale do Proença. Hipótese essa defendida por Santos (1998), que, ao longo de um dos seus capítulos, dedica

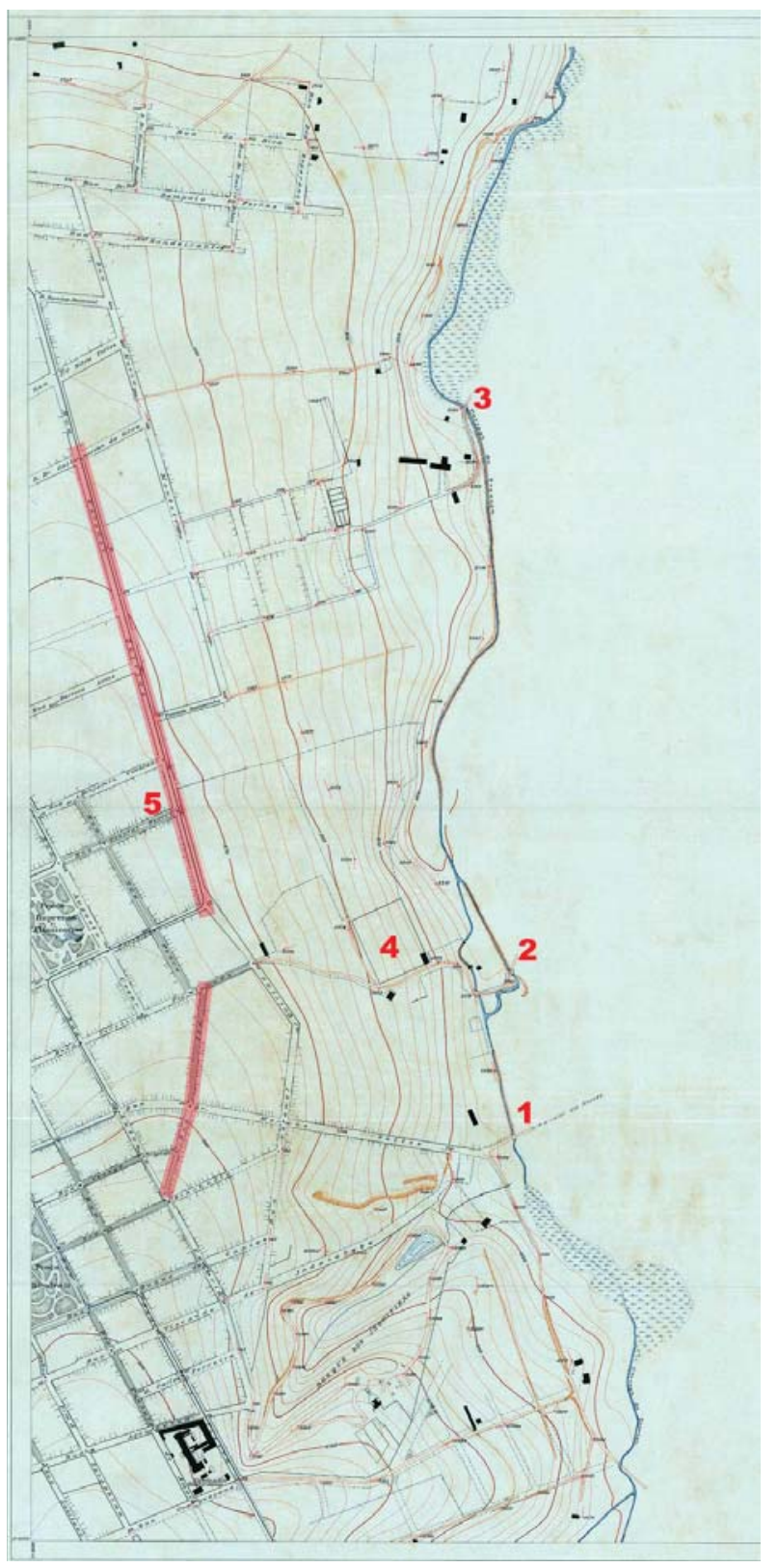

Figura 4 - Detalhe da planta de 1929. Original em escala 1:2000, aqui reduzido à escala das fotos aéreas empregadas na foto-interpretação e reproduzidas adiante. Destacadas em vermelho: (abaixo) rua ltu; (acima) trecho da rua Coronel Quirino, entre Conceição e Guilherme da Silva; ambos são trechos que Pupo (1969) e o presente trabalho apontam pertencer ao traçado da antiga estrada dos Goiases. No limite das áreas representadas na planta, à direita, o curso do Proença, cerca de 500 metros ao Leste da Coronel Quirino e em cota 15 a 20 metros abaixo dessa. No vale, não há nenhuma estrada, mas apenas passagens transversais, nos pontos 1 (caminho para Souzas), 2 e 3. Abaixo do ponto 1 e acima do ponto 3 representam-se brejos (na planta de 1916, escala 1:4000, representam-se brejos inclusive entre 1 e 3). No ponto 4, quadrado, que pode corresponder ao "quadrado para escravos" da propriedade de Sampaio Peixoto, referido em inventário. O ponto 5 marca o encontro da rua General Osório com a Coronel Quirino, onde a primeira encontrava muros da propriedade de Sampaio Peixoto; cf. texto de resolução de 1891. Planta Cadastral (1929). Acervo do Departamento de Documentação, Informação e Cadastro, Secretaria de Planejamento - Prefeitura Municipal de Campinas. 
37. Médico escocês radicado em Campinas. Monarquista, vereador e cidadão polêmico. Sérgio Buarque de Holanda refere-se ao Dr. Ricardo em seu prefácio às memórias deVieira Bueno (BUENO, 1976). Anna García Alaniz, em Doutorado defendido na FFLCH-USP (ALANIZ, 1999), trata desse personagem

38.Cf.Santos (1998,p.82, nota 123).

39. Essa é a localização proposta por Pupo (1969, p. 47) e sustentase tanto no próprio traçado geral da estrada, que evita o vale, quanto, mais particularmente, numa série de caminhos que convergem para esse ponto, num padrão característico de antigos pontos de comércio, conforme comentário mais de talhado no item dedicado à análise do trajeto da estrada por sobre a área da fotografia 60 (Figura 13).

40. Todos os autores consultados concordam que teria sido essa a localização de um dos campinhos, ressalvando tratarse de tradição local, não sendo conhecida prova documental a respeito.

41. Sendo essa a campina que mais diretamente relacionava-se com o pouso, teria sido a primeira a ser explorada. Por outro lado, uma segunda campina teria existido no local de fundação da futura cidade, local que passou a ser ocupado somente quase meio século depois da criação do pouso. Nesse sentido, "campinas velhas" não designaria necessariamente um velho núcleo urbano, mas, eventualmente, o local da campina (clareira) mais antiga, ou seja, a que primeiro teria sido explorada (e, de esforço específico e sistemático à reconstituição do traçado da estrada. Haveria documentação comprobatória de que tivesse sido esse o trajeto, rumando por uma várzea inundável, área de brejos, contra a usança geral das bandeiras e a característica daquela bandeira do segundo Anhanguera em particular?

O trabalho que constrói essa hipótese (SANTOS, 2000) o faz com base na leitura de um texto de 1879 (DAUNT, 1904) que, entretanto, não se presta inequivocamente à conclusão extraída. Na leitura feita por Costa Santos (1998) do texto do Dr. Ricardo Gumbleton Daunt ${ }^{37}$, de onde conclui que o caminho passava pelo vale, importam alguns pressupostos - dados que o texto do Dr. Ricardo não afirma, mas, sim, que, tidos como corretos, determinam a leitura efetuada por Santos (1998). Um desses pressupostos é o de que a "chácara hoje [1879] do Dr. Sampaio Peixoto" se localizava com frente para o vale. Outro, o de que o antigo pouso das Campinas se localizava também no vale, nas proximidades de onde hoje se encontra o viaduto Laurão, cruzamento das vias Norte-Sul e Moraes Sales.

Esse último pressuposto - o entendimento de que o antigo pouso ocupava a baixada do vale do Proença, nas proximidades do atual cruzamento das avenidas Norte-Sul e Moraes Sales (ponto-chave para, da leitura do texto do Dr. Ricardo, concluir-se que o trajeto da estrada rumava pelo vale) - comparece no trabalho de Costa Santos, amparado por tradição historiográfica que afirma ter sido essa a localização do pouso. Com efeito, Costa Santos tem razão, em grande medida, ao chamar a atenção para o fato de que Pupo (1969), ao afirmar localização diversa (vide Figura 3), constitui exceção ${ }^{38}$. É possível, entretanto, recobrar as origens dessa tradição, iniciada em texto de 1944, e afirmar que nela há equívoco, resultante de a denominação "Campinas Velhas" abarcar, no vale do Proença, tanto o local onde efetivamente se encontrava o pouso, numa cota superior, quanto a "aguada" correspondente, em cota inferior. Referências sob a mesma alcunha de "campinas velhas" tanto às redondezas da estrada e do pouso (em nível mais alto), quanto do rio e da aguada (em nível mais baixol, favoreceram o entendimento de que o pouso e o ribeirão correspondiam a uma mesma localização, o que não é correto.

O pouso das três campinas situava-se à beira da estrada, como é natural, no ponto em que essa, correndo pelo platô do atual bairro do Cambuí, mais se aproximava do atual córrego do Proença (avenida Norte-Sul), no cruzamento das atuais rua ltu e avenida Moraes Sales ${ }^{39}$. No ponto correspondente, em cota inferior, no vale do atual córrego do Proença, localizava-se a aguada de que se servia o pouso, aguada que era também um dos três campinhos que davam nome ao então "bairro das Campinas" 40 . Posteriormente, no local do pouso, ao alto, e nessa campina e aguada, ao baixo, teria se formado um pequeno arraial, ou bairro, conhecido, tal como o ribeirão (depois "Proença"), pelo nome de "Campinas Velhas" (OCTAVIO, 1922) (1). $^{4}$

Que pontos distanciados do ribeirão e do vale pertenciam igualmente ao "bairro" das Campinas Velhas o demonstra despacho municipal do ano de 1837, autorizando o cônego Melchior Fernandes Nunes a edificar "no bairro de Campinas Velhas" ${ }^{42}$ um jazigo; o que foi feito e corresponde, é sabido ${ }^{43}$, ao local 
da atual igreja de S. Benedito, em cota elevada e distante mais de 700 metros em linha reta do curso do córrego das Campinas Velhas, depois do Proença.

A respeito do trajeto da estrada e do "lugar" "Campinas Velhas", temse, no referido texto do Dr. Ricardo, de 1879 :

A então estrada de Jundiaí ás minas de Goyaz passava por onde era depois o sítio da Samambaia e chácara de D Maria Fausta; e alcançando o logar depois conhecido por Campinas Velhas, tomava pelo caminho que corre em frente da chacara hoje do Dr. Sampaio Peixoto [...]. No logar - Campinas Velhas - formaram uma clareira onde se fizeram os primeiros ranchos e onde descançavam os viadantes ${ }^{44}$.

Note-se que não se fala aqui que a clareira estivesse à beira do rio.

A seguir, em 1922, o historiador e memorialista da cidade Benedicto Octavio, que em 1915 era transferido do cargo de secretário da Prefeitura para o de secretário da Câmara (pela aposentadoria, neste último, do também historiador e memorialista Leopoldo Amaral), escreve:

O primitivo povoado que viria a ser sede do importante Municipio de Campinas, á beira da estrada de S. Paulo para o sertão, teve inicio junto a um corrego já chamado CampinasVelhas nos princípios do século XIX, e que até hoje conserva esse nome ${ }^{45}$.

No mesmo trabalho, o autor fala ainda da "formação de três nucleos, em que por muito tempo o povoado se constituiu", dos quais " $\bigcirc$ primeiro, Campinas Velhas, á beira da estrada e do ribeirão, formado de algumas casas, se comunicava com o segundo por um caminho que é hoje a rua Moraes Salles" ${ }^{46}$.

Apesar de, nessa exposição, facilmente confundirem-se a estrada e o ribeirão, esse texto é compatível com o entendimento de que estrada e ribeirão correspondem a traçados distintos. Basta lembrar que "Campinas Velhas" não denota exclusivamente partes do vale, mas também partes do platô, para que a afirmativa de que um povoado com tal nome, iniciado junto do córrego, possa ter-se desenvolvido "junto do rio e da estrada", sem que, aqui, a estrada coincida necessariamente com o vale.

De resto, note-se que Octavio, nesse mesmo texto, diz que, depois da bandeira pioneira do segundo Anhanguera, "outros, com certeza, mais tarde, costumavam pousar perto do córrego" 47 . Vindo pela estrada, pousavam perto do córrego. A afirmação é sem razão, caso o autor entendesse que o curso da estrada correspondesse ao do ribeirão. Conclui-se que Octavio (1922) não entendia que a estrada seguisse pelo vale, embora a afirmativa da existência de um primitivo núcleo "à beira da estrada e do ribeirão" deixasse margem para uma leitura nesse sentido.

É em 1944, no trabalho de Maria Estela de Abreu Bergó, apresentado ao X Congresso Brasileiro de Geografia, que se confundem definitivamente os traçados da estrada e do ribeirão: "A zona inicial do povoamento acompanhou o curso do ribeirão de Campinas Velhas, onde os bandeirantes ergueram o rancho ou pouso $[\ldots]^{\prime \prime 48}$. início, mais intensamente). É uma hipótese.

42.Apud Pupo (1969, p. 23).

43. Cf. Pupo (1969, p. 23); Lorette (2003, p. 124132).

44. Ver Daunt (1904, p. 123).

45. Cf. Octavio (1922, p. 11).

46. Idem. Ibidem.

47. Idem. Ibidem.

48. Ver Bergó (1944, p. 643). Cabe lembrar que, apesar das observações de Holanda $(1941 ; 2000)$ e de Ellis Jr. em texto de 1924 (Apud HOLANDA, 2000 , p. 21 , nota 3 ), acima reproduzidas, o entendimento de que as bandeiras se aproveitavam de vias fluviais permanecia vivo à época em que Bergó apresenta esse trabalho. Veja-se por exemplo Taunay (1941). 
49. Cf. Pupo (1969, p. 115); Goulart (1983)
Seguindo o texto de Benedicto Octavio (não diretamente citado, mas incluído na bibliografia), Bergó fala igualmente do desenvolvimento a partir de três núcleos distintos (Campinas Velhas, o local de fundação da freguesia, e Santa Cruz), e ilustra em Planta, que reproduzimos (Figura 5).

Benedicto Octavio falara da ligação dos dois primeiros núcleos pela atual rua Moraes Sales, sendo sabido que essa rua chamara-se anteriormente "rua que vai para Campinas Velhas" ${ }^{49}$. Na Planta com que Bergó ilustra seu trabalho (Figura 5), vê-se que essa autora traçou a ligação seguindo até certa altura da atual avenida Moraes Sales, fazendo então um ângulo de $90^{\circ}$, completando a ligação pela rua Barão de Jaguara, o que não pode corresponder ao trajeto original.

Com efeito, em 1774, quando a capela provisória é erguida, não havia no local quaisquer casas, muito menos arruamentos, menos ainda arruamentos desenvolvidos até o cruzamento das ruas Moraes Sales (hoje avenida) e Barão de Jaguara, relativamente afastado do núcleo original ligreja e praça Bento Quirino). A ligação entre as Campinas Velhas e a atual praça Bento
Figura 5 - Esta planta ilustra trabatho apresentado por Maria Estela de Abreu Bergó ao Congresso Nacional de Geografia de 1944. Vêemse os três núcleos de que fala a autora, baseando-se em Octavio (1922): à esquerda o núcleo 1, "Campinas Velhas", engloba o antigo pouso das Campinas. A ligação proposta entre os núcleos 1 e 2, pelas atuais av. Moraes Sales e rua Barão de Jaguara (destacada em vermelho) contém um ângulo de 90, 0 que não pode corresponder ao trajeto original. Apenas um primeiro trecho da atual Moraes Sales, que (como se pode ver na figura) aponta na direção do núcleo 2, corresponde ao caminho original desde o local do antigo pouso larredores do núcleo 1) ao local onde seria, erguida em 1774, a matriz da nova freguesia (núcleo 2). Maria Estela de Abreu Bergó, Alargamento da área urbana. Croqui de planta urbana (BERGÓ, 1944).

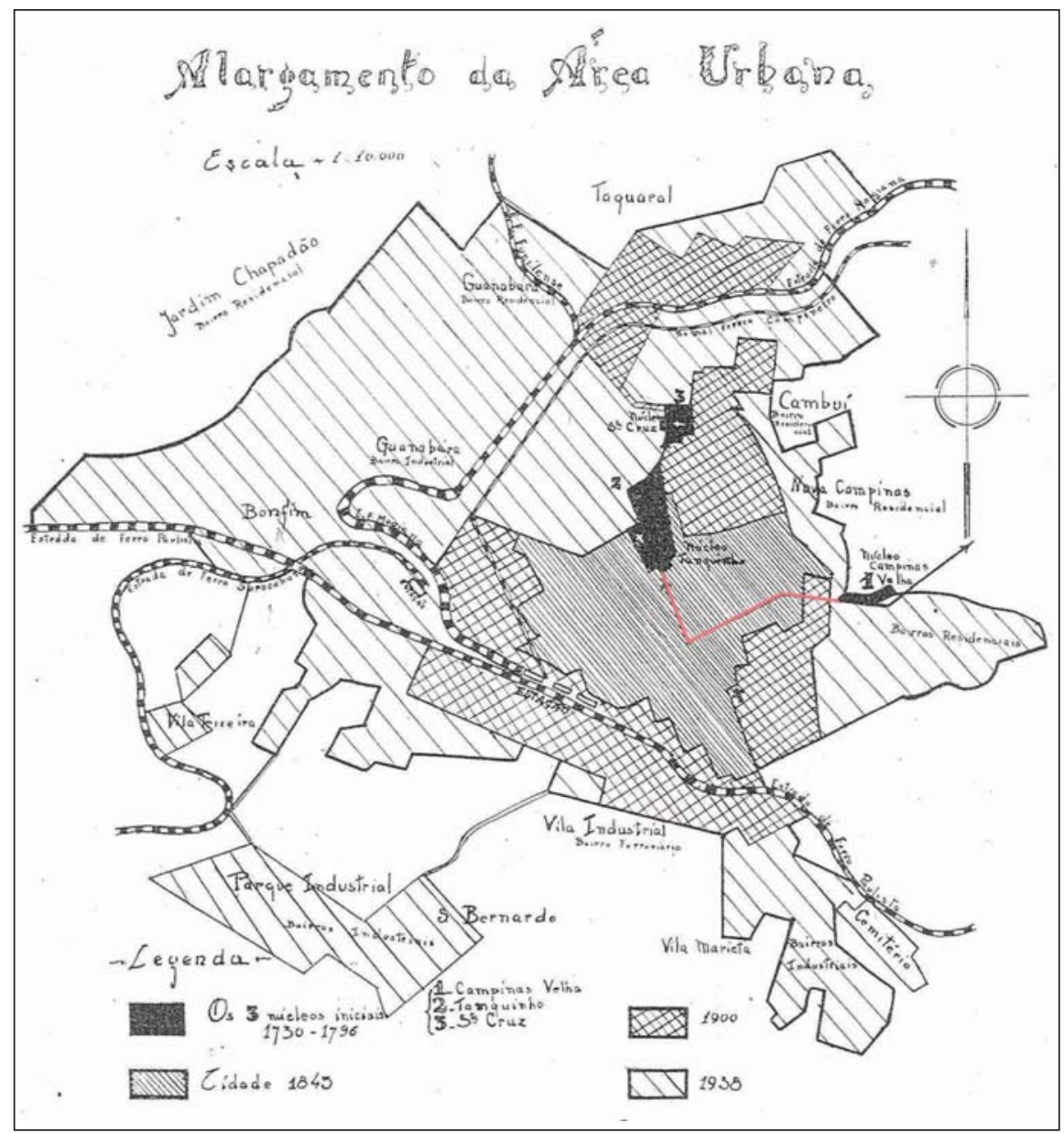


Quirino, existente ainda antes de $1774^{50}$, não poderia, portanto, ter seguido originalmente por dois segmentos em ângulo reto. Como veremos adiante, apenas um trecho da atual avenida Moraes Sales corresponde ao antigo trajeto de ligação das Campinas Velhas à atual praça Bento Quirino, o demais tendo sido desfeito sob o avanço dos arruamentos, emendando-se às ruas Ferreira Penteado e Conceição, em diferentes épocas, conforme estas iam sendo abertas e prolongadas, até a emenda com a atual Moraes Sales, de que o derradeiro trecho do percurso original ganhou o nome.

Campos Jr. (1952, p. 9) será prudente quanto à localização do pouso, reproduzindo os termos de Octávio (1922): indica a "tradição" de que, junto dos "campinhos", "no lugar conhecido pela designação característica de Campinas Velhas, à beira da estrada e do ribeirão, existia um pouso para tropeiros" (grifo nosso) $)^{51}$. Fica claro que, para este pesquisador, o caminho não corria pelo vale, pois, referindo o texto de Ricardo Gumbleton Daunt (1904), "ilustre pesquisador das cousas antigas de Campinas", aponta corretamente que tal texto indica trajeto "pelo antigo cambuizal, hoje bairro do Cambuí"52. Ou seja, pelo platô entre os vales do Proença e do Tanquinho, tal como no croquis de Pupo (Figura 3) e no presente trabalho.

Mas a tese de que o pouso se localizava no vale ganhava terreno. José de Castro Mendes, jornalista, cronista e historiador de fatos locais, na série de cadernos sobre história de Campinas que organiza para o Correio Popular em 1968, afirma: "O pouso das Campinas Velhas localizava-se na baixada da atual avenida Moraes Sales, próximo ao estádio do Guarani, onde existia uma aguada, conhecida como "córrego do Lava-pés", local onde se formou o primeiro núcleo de moradias que deu início à formação da cidade" 53 .

Diga-se, de passagem, a tese de que existiram três núcleos distintos de população, tese, como visto, lançada por Octavio (1 922), seguida por Bergó (1944) e presente na afirmação acima, de Mendes (1968), dos quais, o primeiro, o de Campinas Velhas, anterior àquele em torno da matriz da Freguesia mereceu contundente contestação de Pupo (1969):

[...] não havia qualquer aglomerado urbano, nem mesmo em volta do rancho dos Três Campinhos que era apenas uma 'paragem deserta', afirmativa que concorre para destruir a lenda de que Campinas nasceu de três povoados, quando não se conhece um só documento que indique a existência de um, dois ou três povoados até $1774[\ldots]^{54}$

Em 1974, Benedito Barbosa Pupo ${ }^{55}$, outro jornalista, afirma que o pouso se situava "na atual avenida Dr. Moraes Sales, nas proximidades do ribeirão que corta o bairro da Nova Campinas"50. $\bigcirc$ termo "proximidades" poderia contemplar, inclusive, a localização indicada por Celso Maria de Mello Pupo (1969), também à avenida Moraes Sales, porém em cota superior, afastada cerca de 400 metros do curso do referido ribeirão (Proença), mas não deixa de reforçar o entendimento de que tal pouso se localizasse na baixada do vale, junto ao córrego.

Em mestrado defendido no ano de 1990, Luis Cláudio Bittencourt apresenta em planta o traçado supositício da estrada dos Goiases (Figura 6$)^{57}$.
50. Já antes da construção da capela, essa área, local de um dos campinhos, era freqüentada pelas tropas, em busca de pastagens. Cf. Daunt (1904, p. 123).

51. Santos (1998, p. 83) arrola Octavio (1922) e Campos Jr. (1952) como autores que teriam afirmado localizar-se o pouso no vale.

52. Cf. Campos Jr. (1952, p.9).

53. Cf. Mendes (1968, p. 3). Conhecemos menção ao "córrego Lapa-pés" apenas em d'Alincourt (1975, p. 54), mas referese ao atual canal da avenida Orosimbo Maia.

54.Pupo (1969,p.48). No primeiro capítulo desse livro há documentos que comprovam não existir, na região, aglomerado urbano anterior à ereção em Freguesia.

55.Apesar da identidade do sobrenome, o jornalista Benedito Barbosa e o historiador Celso Maria não são parentes.

56. Pupo (1974, s. p.).

57. Essa e outras plantas do trabalho de Bittencourt estão enfeixadas em volume a parte, anexo ao volume do texto. Em regra, as bibliotecas dispõem do de texto, mas não do outro. $\mathrm{O}$ volume de plantas que utilizamos está no acervo do CAPH (Centro de Apoio à Pesquisa em História) da FFLCH-USP (Faculdade de Filosofia,Letras e Ciências Humanas da Universidade de São Paulo). 
Figura 6 - Reconstituição do trajeto da estrada dos Goiases. Luís Cláudio Bittencourt, Evolução do desenho da cidade. Planta Urbana (BITTENCOURT, 1990, volume anexo, s.n.p.).

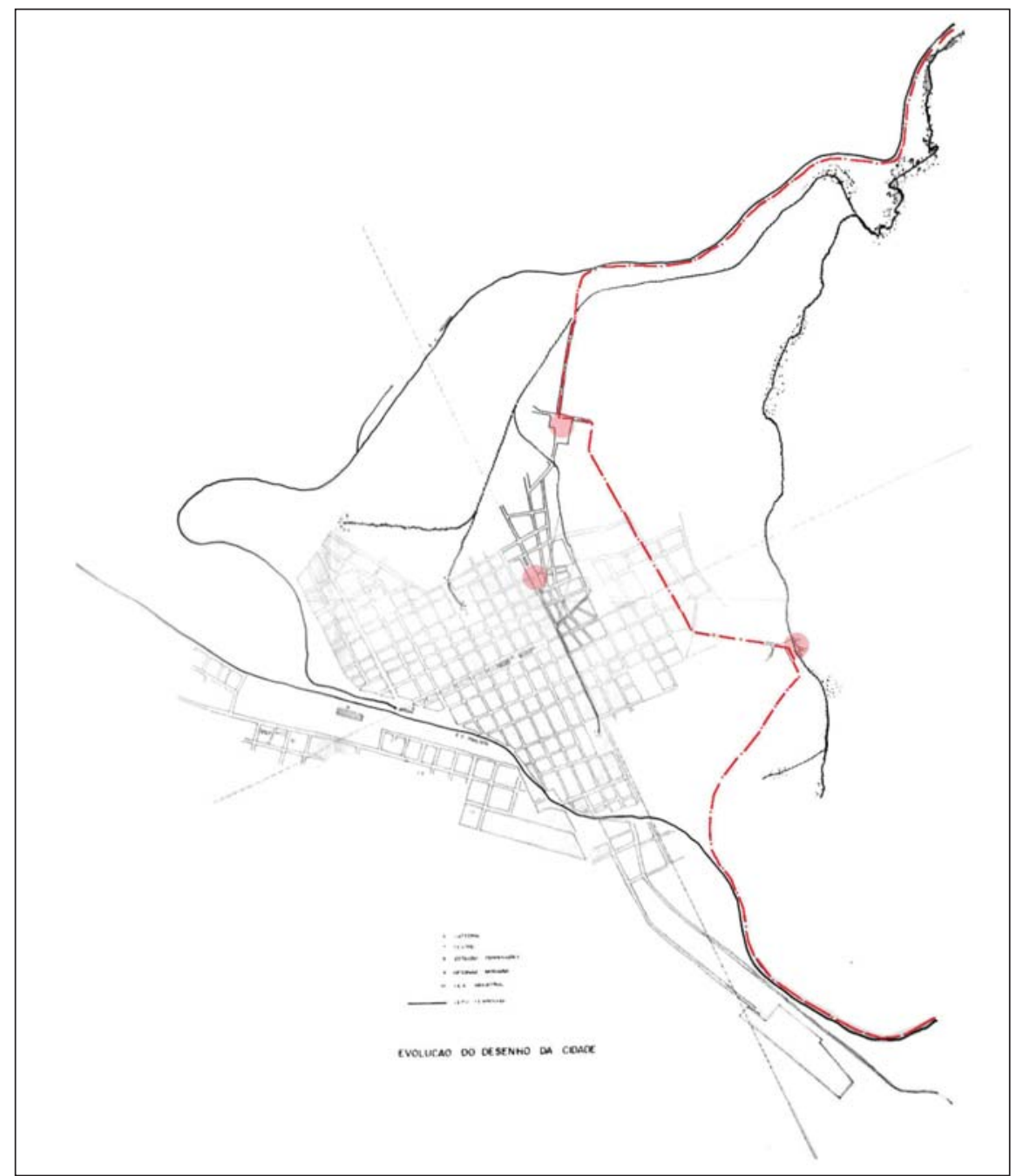

58. Local do pouso, segundo Pupo (1969)
O trajeto proposto segue quase todo ele por regiões elevadas, efetuando-se, entretanto, um desvio a Leste para fazê-lo passar pelo ponto da aguada, suposto local, desde 1944, do pouso das Campinas, como visto.

De Sul a Norte, inicia-se o traçado proposto por Bittencourt (1990), coincidindo com o traçado da linha da Companhia Paulista; deflete à direita, descendo para o vale aproximadamente pelo bordo sul do atual bosque dos Jequitibás; cumprida a passagem pelo local suposto do pouso, no fundo do vale, retoma o trajeto em cota elevada, subindo pela atual avenida Moraes Sales até o cruzamento com a rua ltu ${ }^{58}$, a seguir tomando rumo pela atual avenida Júlio de Mesquita; segue por esta até o largo de Santa Cruz, desde onde segue pela atual rua Major Sólon, cruzando o vale do Anhumas ou Serafim (atual avenida Orosimbo Maia), subindo um trecho inicial da rua Paula Bueno até o cruzamento dessa com a linha da Companhia Mogiana e do ramal férreo; tal como no início, termina o trajeto representado acompanhando o trajeto da linha férrea. 
No texto não há justificativa para a escolha desse traçado. $\bigcirc$ traçado da linha da Companhia Paulista, no trecho em que o autor faz corresponder dito traçado com o do caminho dos Goiases, é obra que envolveu transposição de gargantas por meio de aterros ${ }^{59}$, sendo originalmente inadequado para uma trilha. Não conhecemos referências que apontassem a continuidade do percurso pela atual avenida Júlio de Mesquita, por onde, a seguir, o autor faz passar a trilha. No trecho final, teria a escolha de fazer o traçado acompanhar a linha da Companhia Mogiana derivado do conhecido fato de que o traçado dessa via férrea corresponde, grosso modo, ao da antiga estrada dos Goiases?

Em 1996, é publicado o livro de Amaral Lapa, historiador. Sobre os campinhos e a estrada, anota:

O atual largo de Santa Cruz era o terceiro campinho das três clareiras na mata que deram origem ao povoamento local e à cidade [...]. O primeiro ficava numa localização para nós ainda imprecisa, numa área, segundo os estudiosos, por cima da qual passa possivelmente o atual viaduto Laurão, estendendo-se até onde hoje está o estádio do Guarany F. C., de qualquer maneira às margens do córrego do Proença. $O$ segundo, também relativamente próximo à água corrente (córrego do Tanquinho), ficava onde hoje está a praça Bento Quirino [...]. Quanto, ainda, à sua localização no espaço físico que seria ocupado pela cidade, o primeiro campinho ficava próximo do caminho de quem vinha de São Paulo e Jundiaí, em demanda de Goiás [...] enquanto os outros dois campinhos - atuais praça Bento Quirino e largo de Santa Cruz - ficavam numa seqüência mais lógica de direção geográfica com relação a São Paulo. Entretanto, parecem-nos ainda estranhas tais localizações ${ }^{60}$.

$\bigcirc$ estranhamento de Lapa pode ser creditado, pelo menos em parte, ao fato de que, no conjunto, as diferentes afirmativas a respeito (díspares, como vistol são tão pouco coerentes quanto esclarecedoras. Por outro lado, as considerações do autor quanto a uma "seqüência mais lógica de direção geográfica com relação a São Paulo" tornam-se bastante claras quando se tem à vista a proposta de Bittencourt para o trajeto do caminho e a localização dos pousos $^{61}$. De fato, é na planta apresentada por esse autor (Figura 6) que se nota como a situação dos campinhos - que o autor localiza na praça Bento Quirino e no largo de Santa Cruz - está em continuidade com o traçado proposto para a estrada dos Goiases, não fosse o desvio executado para fazê-lo passar pela aguada do vale do Proença.

Finalmente, tem-se o doutorado de Antônio da Costa Santos, de 1998. Esse trabalho persegue, de uma perspectiva local, o processo histórico da apropriação (e especulação) fundiária no Brasil, desde os primórdios da ocupação da futura cidade até o momento da escrita. Centrando-se num objeto particular, Santos (1998) enfoca as sucessivas etapas de sua apropriação e conformação econômico-social: a análise concentra-se na antiga fazenda Paraíso, dada como parte da antiga sesmaria de Antônio Cunha de Abreu, depois engenho de cana, fazenda de café e loteamento urbano ${ }^{62}$. No primeiro capítulo, na seção intitulada - A configuração de uma fazenda miticamente intitulada Paraíso na porta de entrada da freguesia campineira -, o autor procede a uma circunstanciada reconstituição do trajeto da estrada dos Goiases.
59. A observação das fotografias aéreas no estereoscópio permite ver de modo nítido.

60. Cf. Lapa (1996, p. 65).

61. Lapa refere em nota, ao final do trecho transcrito: "O raciocínio que fazemos baseia-se nas pesquisas e estudos de Celso Maria de Mello Pupo $(1969$, p. 47) que chega a desenhar sobe a planta da cidade o que teria sido o trajeto da estrada de Goiás e a localização dos três campinhos" (LAPA , 1996, p.65).Entretanto o raciocínio de Lapa quanto à "seqüência mais lógica de direção geográfica" fica claro à vista da proposta de Bittencourt, não da de Pupo; de resto, a localização do terceiro campinho, afirmada no trecho de Lapa (1996) citado, ou seja, no largo de Santa Cruz, difere da sugerida por $\mathrm{Pu}-$ po (1969, p. 47) e segue a adotada, entre outros, por Bittencourt (1990).

62. O edifício da antiga sede dessa fazenda pertencia desde 1978 a Santos (assassinado em 2001, quando no exercício do mandato de prefeito de Campinas). Esse edifício foi tombado, em 1986, pelo Conselho de Defesa do Patrimônio Histórico,Arqueológico, Artístico e Arquitetônico do Estado de São Paulo (Condephaat) e, em 1992, pelo Conselho de Defesa do Patrimônio Cultural de Campinas (Condepacc). Cf. Santos (1998, cap. 3, n. 227, 248, 249). 
63. Ver Santos (1998, p. 68, n. 109).

64. A citada nota 109 se estende pelas páginas 69 e 70 ,e traz as referências completas da documentação que listamos resumidamente.

65. D. Luís Antônio Botelho de Mourão, o Morgado de Mateus. Governou a capitania de S. Paulo entre 1765 e 1775 , sendo responsável pela implementação de uma estratégia de ocupação do território a que a criação da freguesia de Campinas não deixa de estar vinculada. Veja-se, a respeito, Bellotto (1979).
No trecho em causa, a reconstituição (Figura 7) apresenta duas variantes: um trajeto mais ocidental, que segue pela ałual rua Barão de Jaguara; e outro, mais oriental, que segue pelo vale do Proença. O primeiro, saindo do atual centro, antiga vila, segue pela atual rua Major Sólon e avenida Orosimbo Maia, até unir-se ao segundo, na barra do córrego das Anhumas lou Serafim, atual avenida Orosimbo Maia) com o do Proença (avenida Norte-Sul). A avenida Moraes Sales é também assinalada como um ramal que liga essas variantes. $\bigcirc$ traçado ocidental, pela rua Barão de Jaguara, atende à descrição de Luiz d'Álincourt, em seu relato do ano de 1818. A variante pelo vale do Proença é aquela que, segundo Costa Santos, corresponderia ao traçado original da estrada dos Goiases.

A nota 109 do trabalho em causa descreve a base documental e os métodos empregados nessa reconstituição $0^{63}$. Resumidamente ${ }^{64}$, segundo as indicações, foram utilizados: um conjunto registros de correspondência oficial do governo do morgado de Mateus ${ }^{65}$, pertencentes à Biblioteca Nacional; três cartas setecentistas da região do atual estado de São Paulo; relatos de viajantes. Uma base cartográfica foi especialmente montada para efeito da reconstituição, constituída por imagem de satélite integrada a informações de drenagem, estradas e altimetria retiradas de cartas do IBGE. As informações hauridas nas fontes
Figura 7 - A derivação à esquerda (ocidental) atravessa o centro da cidade pela atual rua Barão de Jaguara, seguindo o relato de D'Alincourt de sua viagem de 1818 , relato que Santos (1998) reproduz em nota. A derivação à direita segue pelo vale do Proença e seria, segundo Santos (1998), a rota da antiga estrada dos Goiases. A ligação entre os dois percursos ao centro da imagem dá-se pela atual av. Moraes Sales. Antônio da Costa Santos, Reconstituição do trajeto da estrada dos Goiases sobre a atual mancha urbana de Campinas (SANTOS, 1998, p. 71).

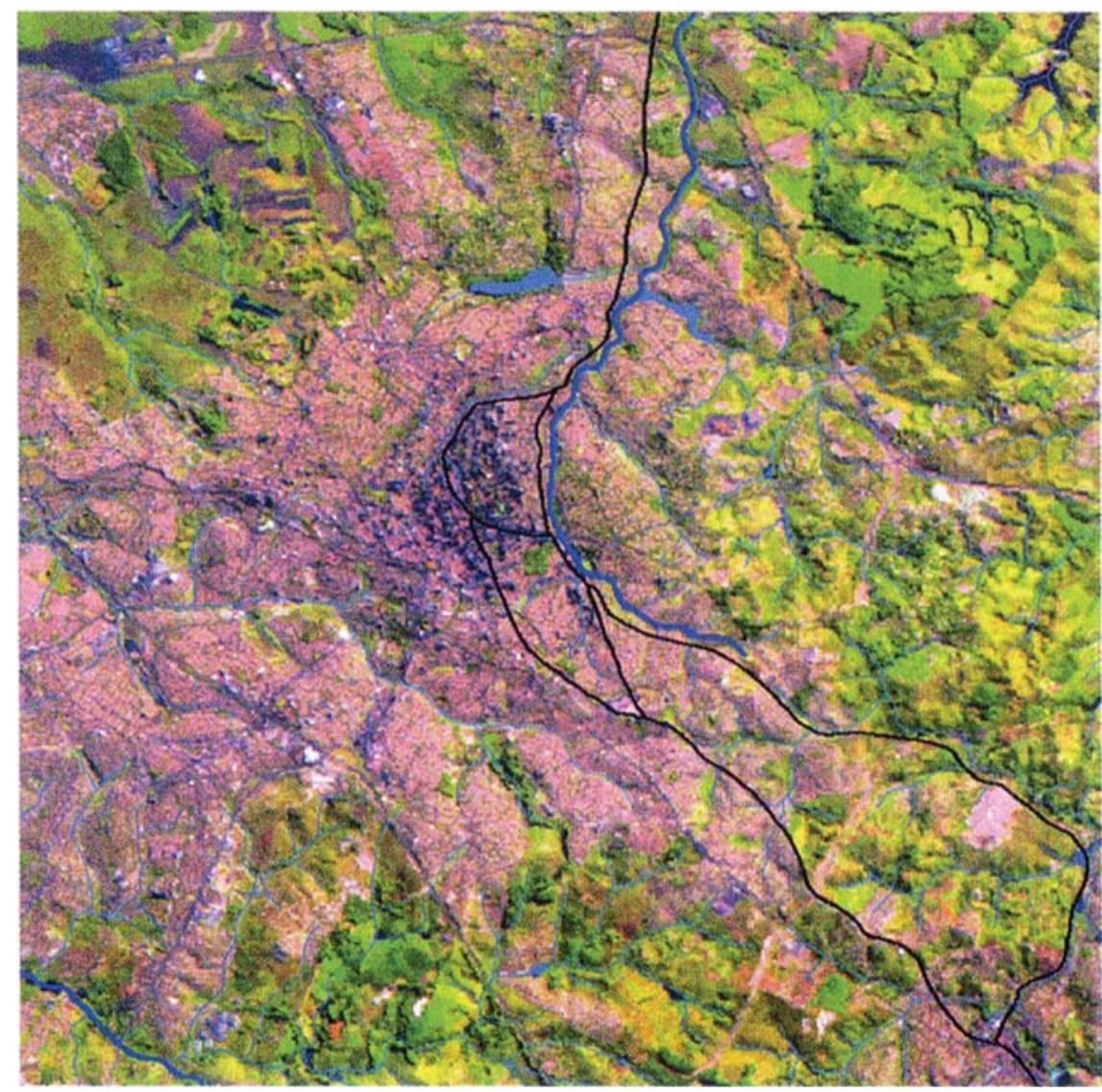

Anais do Museu Paulista.v. 14.n.2. jul.- dez. 2006. 
citadas foram comparadas com a base cartográfica assim obtida, efetuando-se a reconstituição do traçado, no trecho desde Jundiaí até Mogi. Nos trechos urbanos, em substituição da referida carta, utilizou-se, montada sobre imagem de satélite, uma foto-carta - ou seja, uma carta constituída por mosaico de fotografias aéreas, montadas digitalmente - compatibilizada com a imagem de satélite ${ }^{66}$.

A documentação de época, citada, e os relatos de viajantes não se prestaram, entretanto, para a reconstituição do traçado no trecho em questão ${ }^{67}$. No trecho da atual mancha urbana da cidade, a documentação que serve de base para a reconstituição apresentada por Santos (1998) resume-se ao contido no texto Reminiscências do districto de Campinas em bairro, freguesia e villa, do Dr. Ricardo Gumbleton Daunt, datado de 29 de Julho de 1879, primeiramente publicado por seu filho, no catálogo da exposição regional de Campinas, de 1885, e depois reproduzido alhures ${ }^{68}$.

Como anota Costa Santos, depois de ter passado em revista as anotações de diversos historiadores e cronistas locais a respeito do traçado da estrada, o texto do Dr. Ricardo "constitui-se na única fonte secundária existente a descrever o percurso dos viajantes, precisamente no trecho campineiro do antigo caminho $[\ldots]^{\prime \prime 69}$.

Acrescentemos que, se essa fonte secundária é a "única" a oferecer dados que se prestam à reconstituição que Santos (1998) enceta, por outro lado, nessa reconstituição, não interferem dados da considerável documentação primária recolhida pelo autor e empregada em seu trabalho ${ }^{70}$.

A reconstituição de Costa Santos (1 998) do traçado da antiga estrada dos Goiases no trecho em causa baseia-se, portanto, numa leitura (interpretação) dos termos do registro do Dr. Ricardo. $\bigcirc$ trecho desse texto que servirá de base à reconstituição é o seguinte:

A então estrada de Jundiaí ás minas de Goyaz passava por onde era depois o sítio da Samambaia e chácara de D. Maria Fausta; e alcançando o logar depois conhecido por Campinas Velhas, tomava pelo caminho que corre em frente da chacara hoje do Dr. Sampaio Peixoto, até cahir na actual estrada do Taquaral, ou de Mogy-Mirim ${ }^{71}$.

O primeiro pressuposto que determina a leitura feita por Santos (1998) dessa descrição é o de que o "logar depois conhecido por Campinas Velhas", que no caso se refere especificamente ao local do pouso, à beira da estrada, fosse o local da aguada existente ainda no século XIX sob o atual viaduto do Laurão. Conforme já expusemos, esse pressuposto, embora seja o entendimento predominante entre os trabalhos recentes sobre a história da cidade, é equívoco: o pouso, embora relacionando-se com a aguada, existiu em cota superior, no cruzamento das atuais avenida Morais Sales e rua ltu, como Pupo (1969) indica, e as evidências colhidas no presente trabalho sustentam. Não se tem registro do entendimento de que pouso e aguada coincidiam anteriormente ao trabalho de Bergó, em 1944, onde isso irrompe através de uma leitura possível, mas não necessariamente correta, do texto de Benedicto Octávio, de 1922.
66. As fotografias aéreas utilizadas por Santos são de vôo de 1994. Note-se que o emprego das fotografias aéreas difere daquele efetuado no presente trabalho. Com efeito, segundo a descrição (SANTOS, 1998, loc. cit.), as fotografias foram aí utilizadas como foto-carta, imagem plana resultante da montagem ("mosaicagem") de um conjunto de chapas.Para a reconstituição apresentada no presente trabalho foi fundamental a utilização dessas chapas, mas soltas, onde pares sucessivos, vistos ao estereoscópio, restituem a visão em $3 \mathrm{D}$ da formação topográfica, sendo a dimensão vertical destacada 10 vezes com relação ao natural.

67.Taunay já havia apontado a insuficiência da documentação de época para uma reconstituição precisa dos traçados das bandeiras. É citado por Santos Filho (1969, p. 7,n. 1), que completa:"A documentação encontrada no Arquivo do Estado de São Paulo sôbre o caminho para as minas de Cuiabá foi publicada na série 'Documentos Interessantes para a história e costumes de São Paulo', do mesmo arquivo, vols. 12 (págs. 15 , 16), 20 (págs. 71, 72, 110, 111, 112, 156), 22 (págs. 39, 179), 24 (págs. 57, 229 e 234), 32 (págs. 82 a 85 $158,159)$ [...] não há informes de natureza topográfica que permitam reconstituição veraz do itinerário seguido por Luís Pedroso de Barros em sua picada".

68. Na Revista do Centro de Ciências, Letras e Artes de Campinas, em 1904; no número inaugural do suplemento especial História de Campinas, do jornal Correio Popular, em 1968.

69. Santos (1998, p. 83) 
70. Com efeito, não há recurso a outra documentação ao longo do trecho que trata da reconstituição do trajeto (SANTOS 1998, p. 83-84). Mais adiante (p. 93), ao transcrever um inventário e partilha de seu objeto (chácara Paraíso), de 1833 , no qual aparece como confrontante o nome de "Maria Fausta", citado por Daunt (1904) como proprietária lindeira da estrada dos Goiases, Costa Santos registra em nota: "Confirma-se, através dessa confrontante, a travessia do caminho das Minas dos Goyases pelo engenho de cana do padre Manoel José Fernandes Pinto [futura chácara $\mathrm{Pa}$ raíso], localizado no antigo pouso das Campinas Velhas [pouso que o autor, apoiado na tradição já comentada, localiza no vale do Proença]" (op. cit. p. 93 n. 158). Entretanto, não apenas o registro da confrontante não indica a passagem do caminho pelo vale, como, pelo contrá rio, um outro trecho do mesmo inventário (onde também se refere Maria Fausta) reforça o traçado apresentado por Pupo (1969) e pelo presente trabalho. De fato, lê-se: "[...] Segue pela estrada adiante para a beirada da cidade até ganhar um es pigão dividindo com terras de Maria Fausta [...]" (apud SANTOS, loc. cit.) Ou seja: a estrada, saindo da cidade (em direção a São Paulo), tomava um $e$ pigão (não um vale!), que correspondia a uma divi sa das terras de Maria Fausta, citadas por Daunt (1904).

71. Daunt (1904, p. 123) Citado por Santos $(2000$ p. 83)
O segundo pressuposto que determina a leitura feita por Santos (1 998) da descrição de Daunt (1904) é o de que a "frente da chácara hoje [1879] do Dr. Sampaio Peixoto" seria localizada junto do vale do Proença, ou seja, que a divisa ou muro fronteiro dessa chácara correspondia a um trecho do vale. Pode-se, entretanto, afirmar com segurança que a frente dessa chácara se situava à atual rua Coronel Quirino - grosso modo paralela ao vale, mas em cota superior, na extremidade Leste do platô existente entre o dito vale do Proença e o vale do Tanquinho. É o que passamos a demonstrar.

Preliminarmente, cabe lembrar que, em São Paulo, os vales do Anhangabaú e do Tamanduateí correspondiam sempre a fundos das propriedades. Os arruamentos ficavam em cota superior, no platô, e apenas os quintais abriam para os vales. Assim também se dava em Campinas, onde as propriedades lindeiras da atual rua Luzitana, antiga "rua de baixo", no lado Leste, davam fundos para o vale do Tanquinho, onde não havia arruamento. De fato, vales brejosos que eram, somente seriam arruados quando já bastante avançada a urbanização desses núcleos - no caso do vale do Tanquinho, o seu "saneamento", já previsto desde fins do século XIX, somente se efetivou nos anos de 1920 e 1930, com a abertura da atual avenida Anchieta desde a rua Benjamin Constant, primeiramente até a atual Guilherme da Silva (trecho finalizado no início de 1926) (ROSSETTO, 2006, p. 206), depois até a atual avenida Orosimbo Maia (já nos anos 30). 0 saneamento do vale do Proença é ainda posterior.

Registrada essa preliminar, passemos à consideração das razões que levaram Costa Santos (1998) a pressupor que a chácara em causa dava frente para o vale do Proença, para, a seguir, expor as razões e documentos que atestam que a frente dessa chácara corresponde a trecho da atual rua Coronel Quirino.

"Dr. Sampaio Peixoto" do texto é Carlos Sampaio Peixoto, de apelido o "Sampainho" (CAMILLO, 1998, p. 66), dono de uma olaria inaugurada em 1867 e bem conhecida da historiografia: primeira olaria mecanizada da então Província, a esse título é lembrada por Lemos (1989, p. 41), pioneirismo realçado por Pereira $(2004$, p. 98, n. 6), ao apontar que nela o uso de maquinário para fabricação de tijolos dava-se um ano depois da invenção das mesmas na Inglaterra, onde "só esporadicamente foram utilizadas"; Homem (1996, p. 91, 93) refere ter sido esta a olaria a fornecer os tijolos para o primeiro palacete paulistano a ser construído recuado do alinhamento, com jardim de frente. $\bigcirc$ mesmo empreendimento contava, ainda, com fundição e moinho, tendo a olaria recebido de D. Pedro II a distinção de "Imperial" antes de 1875 (CAMILLO, 1998, p. 66-69).

Costa Santos (1998, p. 83) afirma que "a mencionada propriedade era composta por um conjunto arquitetônico de produção cerâmica, importante no Império, devidamente registrada na Planta da Cidade de Campinas de 1929, à beira do córrego das Campinas Velhas [depois córrego do Proença]" Igrifo nosso).

A planta de 1929 resulta de trabalho contratado em 1927 aos engenheiros Jorge Macedo Vieira e Carl Alexander Oelsner, entregue à Prefeitura 
em agosto de 1929. Segundo a descrição do material, constante do Relatório da Prefeitura relativo aos serviços executados em 1929, foram entregues: um jogo de plantas em escala 1:1000, outro em escala 1:2000, e uma planta geral em escala 1:5000, cada qual com original e duas cópias, além de cadernos de cálculo e outros materiais. Ainda hoje os originais dessas plantas encontram-se arquivados no Departamento de Documentação, Informação e Cadastro (DIDC) da Secretaria Municipal de Planejamento e Meio Ambiente (Seplama) da Prefeitura Municipal de Campinas ${ }^{72}$. Em nenhuma delas há indicação nominal da propriedade de Carlos Sampaio Peixoto, ou de "olaria", ao longo do vale do Proença. De resto, note-se que, segundo Camillo (1998, p. 66), a referida olaria encerrou suas atividades antes do final do século XIX.

Em um dos mapas constantes do trabalho de Bittencourt (1990), que consiste em anotações sobre planta editada pela casa Genoud em 1916, está marcado em amarelo um conjunto de edificações próximo à aguada, cruzamento das atuais avenidas Morais Sales e Norte-Sul (Figura 8). A marcação em amarelo corresponde, segundo a legenda, às "primeiras oficinas e olarias". Presume-se
72. Na gestão do Dr. Jorge Nicolau à frente do DIDC foi digitalizado grande volume de documentos, bem como algumas plantas históricas da cidade - do próprio acervo desse órgão e de outros acervos públicos da cidade.Articulado a esse esforço, o autor, em 2004 , buscou meios de digitalizar as plantas em causa, que apresentavam a dificuldade de terem dimensões maiores que as da boca dos scanners de que a Prefeitura se utilizava $(90 \mathrm{~cm})$. Em 2005 , essas plantas foram finalmente digitalizadas, no mesmo scanner de 90 $\mathrm{cm}$ de boca, em duas par-

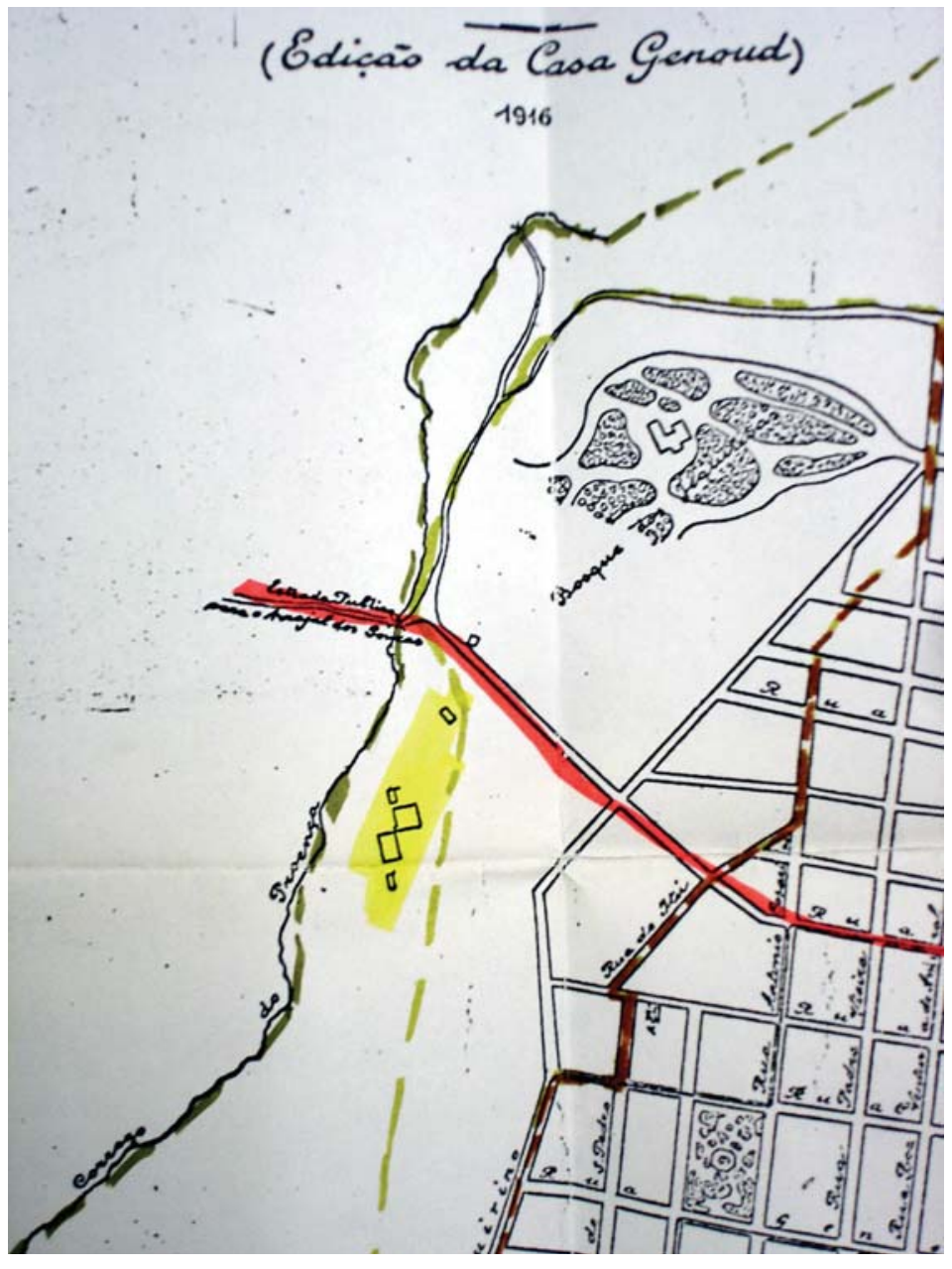

Figura 8 - Neste detalhe de planta de 1916 (com o Norte para baixo), Bittencourt (1990) marca, em amarelo, as "primeiras oficinas e olarias" da cidade. No detalhe, também marcadas em amarelo, o que seriam as instalações da Imperial Olaria, de Sampaio Peixoto. Casa Genoud (Ed.), Detalhe de planta urbana de Campinas (1916), com indicações de Luís Cláudio Bittencourt (1990, volume anexo, s.n.p.). 
tes cada, em projeto financiado pela Fapesp e coordenado pelo prof Dr. Luís Cláudio Bittencourt.

73. Cabe lembrar aqui que Bittencourt era pessoa relacionada a Costa Santos, tendo sido mem bro da equipe de governo desse último, quando Prefeito.

74.Apud Camillo (1998, p. 67)

75.Até a recente digitalização desse material, cf. referido na nota 68 , ne nhuma dessas plantas havia sido referida ou reproduzida em trabalhos sobre a cidade. Por "planta de 1929" entendia-se cópias da planta geral, em escala 1:5000.

76. Inventário de D. Ma ria Carolina da Silva Sampaio (Centro de Memória da Unicamp-TJC, $3 .^{\circ}$ ofício, cx. 356 , pr. 7400, pasta 31-2).

77. Planta da cidade de Campinas e seus edifícios principais, levantada em 1878 pelo engenheiro Luiz Pucci. Reproduzida em caderno anexo a Bittencourt (1990) e em Rossetto (2006, p. 31). que o autor tenha localizado aqui as instalações da antiga olaria de Sampaio Peixoto, sendo possível que informação nesse sentido tenha sido presente a Costa Santos $^{73}$.

Nem Bittencourt (1990) nem Costa Santos (1998) dão as razões ou referências que tornaram possível determinar ter sido essa a localização da olaria de Sampaio Peixoto. É possível, e mesmo provável, que o local assinalado em planta por Bittencourt (1990) corresponda, de fato, às instalações dessa olaria, pois edificações representadas nas plantas de 1929 aproximadamente no mesmo local podem corresponder a algumas das instalações descritas pelo jornalista Francisco Quirino dos Santos em $1870^{74}$ e de outras referidas no inventário desse imóvel, de 1880, citado mais adiante. É hipótese que os indícios disponíveis apontam e que nenhum dado desmente.

As intervenções representadas na planta de 1929 e que parecem corresponder a instalações da olaria, segundo descrições existentes, são um desvio, possivelmente um canal artificial, do córrego do Proença, junto do qual estão representadas duas pequenas edificações e uma área murada em forma de quadrado. O primeiro poderia corresponder ao canal descrito por Quirino dos Santos (apud CAMILLO, 1998, p. 67); o segundo, ao "quadrado para escravos" referido no inventário. Esse último aparece apenas nas plantas de 1929 em escala 1:2000 e 1:1000, sendo ausentes da planta geral em escala 1:5000, única difundida entre os pesquisadores até data recente ${ }^{75}$.

Caso se verifique efetivamente essa correspondência le esta seja efetivamente a localização das instalações da antiga olaria), isso significará que tais instalações ficavam junto ao ribeiro, nos fundos da propriedade do sr. Sampaio Peixoto, que tinha frente para a rua Coronel Quirino, como a lógica dos assentamentos sugere e como os documentos comprovam.

A 9 de março de 1880 falecia a esposa de Carlos Sampaio Peixoto, D. Luisa Carolina da Silva Sampaio. Do inventário a que se procede, consta a chácara, compreendendo "olaria, casa de fundição e moinho", que é assim descrita e avaliada:

Pela chacara comprehendendo os terrenos restantes, dividindo pelo lado da estrada, onde chega as cincoenta braças descriptas, pelos fundos com João Ferraz de Campos Souza e Elisiario Ferreira, e bem como por um lado e por outro com terrenos que foi de José Claudino e o mesmo João Ferraz de Campos Souza, comprehendendo todas as bemfeitorias existentes na mesma chacara, como quadrado para escravos, caza, olaria, caza de fundição, moinho, etcoetera, etcoetera, a quantia de vinte mil reis $^{76}$.

Não bastasse a referência à olaria, a existência de fundição e moinho tornam absolutamente seguro se tratar da descrição da propriedade que contém a "Imperial Olaria" de Sampaio Peixoto. A chácara faz frente "na estrada", posto que "pelos fundos" "e bem como por um lado e por outro" são outras as divisas citadas.

Esse inventário é de 1880. A conhecida planta de $1878^{77}$ não representa nenhum arruamento ou estrada no curso do vale do Proença, que consistia uma área inundável e brejosa e que, como tal, repetimos, é representada 
ainda nas plantas de 1916 e 1929 (Figura 4), sempre sem nenhum arruamento ou estrada a ocupar o dito brejo.

Em meados de 1881, ano seguinte ao do inventário supra e dois a seguir à data do texto do Dr. Ricardo, é aberta a rua Coronel Quirino ${ }^{78}$. Em texto de memorialística, escrito no primeiro lustro do século XX, o cidadão Custódio Manoel Alves anota:

Foi depois aberta a Rua Coronel Quirino, em direção á Santa Cruz; antes de ser aberta, havia uma estrada alli, antigamente, nos fundos das chácaras do Dr. Sampaio, do Lourenço Guedes e do terreno do comendador Soares, entre as chacaras do Sampainho e do Claudino, hoje do Sr. Francisco Bueno e do Sr. Rodovalho ${ }^{79}$.

Assim, dois anos depois do texto do Dr. Ricardo, é aberta a rua Coronel Quirino onde antes havia uma estrada e entre as chácaras do Sampainho - Antônio Carlos de Sampaio Peixoto - e "do Claudino".

A "estrada" referida no inventário de 1880 como limite fronteiro do imóvel não é, portanto, outra senão aquela que, já no ano seguinte, dá lugar à rua Coronel Quirino.

Como evidência suplementar de que a frente da chácara do Dr. Antônio Carlos de Sampaio Peixoto se localizava em trecho da atual rua Coronel Quirino, apresentamos um trecho do texto da Resolução municipal n. 66, do ano de 1891, fixando nova linha divisória das duas freguesias que a cidade compreendia desde 1870, onde se lê, a certa altura: "[...] tomando a rua General Osório até os muros do cidadão Antônio C. de Sampaio Peixoto [...]". Ora, a rua General Osório nunca chegou até o vale do Proença. Ainda hoje, conhece-se sua extremidade, a Leste, no encontro com a rua Coronel Quirino.

Assim, nem o "lugar depois conhecido por Campinas Velhas", nem a "frente da chácara hoje [1879] do Dr. Sampaio Peixoto", referências do trajeto da antiga estrada dos Goiases segundo o texto de Daunt (1904), indicam passagem pelo vale do Proença. $\bigcirc$ primeiro refere o lugar do pouso, que não corresponde ao da aguada; o segundo, um trecho da atual Coronel Quirino. Costa Santos (1998), tendo compreendido essa descrição, até essa parte, como indicativa de trajeto pelo vale do Proença, prosseguirá a sua reconstituição, ou seja, sua leitura do texto de Daunt (1904), do seguinte modo:

A partir dessa chácara [chácara de Sampaio Peixoto], ainda segundo Daunt (1879), o viajante ultrapassaria confortavelmente, como até então fizera, numa mesma cota, a 'barra do Córrego das Campinas Velhas com outro córrego que vai da Vila', esse último, originalmente denominado Tanquinho, Barbosa, Serafim ou Canal do Saneamento da avenida Orosimbo Maia $[\ldots]^{80}$.

Ou seja, Costa Santos, fazendo o caminho passar pela aguada (sob o atual viaduto Laurão) e prosseguir pelo vale, continua a mostrar o caminho seguindo pelo mesmo vale até à barra do Proença com "outro córrego que vem da Vila", atual conjunção das avenidas Norte-Sul e Orosimbo Maia. Entretanto, essa seqüência, diferentemente do sugerido, não tem apoio no texto de Daunt
78. Cf. Goulart (1983) e documentos infra.

79. Custódio Manoel Alves, Notas sobre Campinas, apud Duarte (1904, p. 141). O texto não é datado, mas o autor, falecido em 1904, registra a certa altura (p. 140): "onde hoje se está erigindo a estatua de Carlos Gomes".

80. Santos (1998, p. 84) 
81. Documento doado ao Museu da Cúria Metropolitana de Campinas pela família Abreu Soares; publicado por Celso Maria de Mello Pupo no Diário do Povo de 11 nov. 1962 Cf. Santos (1998, p. 88 nota 143), que também reproduz o documento.

82. Daunt (1904, p. 123). Citado por Santos (2000, p. 83).

83. Edital de 12 de Setembro de 1927:"[...] rua Paula Bueno (commendador Francisco de Paula Bueno) - antiga estrada do Taquaral, do canal do Saneamento até o alto do Taquaral".

84. Sobre esse ponto, ve ja-se ainda as considerações infra, quando da exposição da foto-interpretação sobre a área da chapa n. 60 do levantamento aéreo utilizado.
(1904, original de 1879), que não faz nenhuma referência à dita barra, como de resto não faz nenhuma referência ao Proença. $\bigcirc$ trecho entre aspas no texto de Santos (1998) é retirado de uma Carta de Confirmação de Data de Sesmaria Conferida pelo Príncipe Regente em 12 de Setembro de 1806, documento que registra ser Manoel Fernandes de Sampayo "senhor e possuidor de três sítios e das terras a eles pertencentes, na paragem chamada Barra do Córrego das Campinas Velhas com outro córrego que vai da Vila"81, sem fazer qualquer referência a "estrada" ou "caminho" dos goiases, ou simplesmente "estrada" ou "caminho", ou a quaisquer dos termos da descrição de Daunt. Nessa, como já transcrito, lê-se:

[...] e alcançando o logar depois conhecido por Campinas Velhas, tomava pelo caminho que corre em frente da chacara hoje do Dr. Sampaio Peixoto, até cahir na actual estrada do Taquaral, ou de Mogy-Mirim ${ }^{82}$.

Assim, segundo Daunt (1904), depois de ter passado pela frente da chácara do Dr. Sampaio Peixoto, o caminho corre "até cahir na actual estrada do Taquaral, ou de Mogy-Mirim", cuja localização é conhecida, pois veio a chamar-se "rua Paula Bueno" em 192783.

Considerando-se que a "frente da chacara hoje do Dr. Sampaio Peixoto" corresponde a parte da atual rua Coronel Quirino, a seqüência pela atual rua Paula Bueno, como apontava o croquis de Pupo (1969) e como aponta o presente trabalho, coloca-se com naturalidade, em termos geográficos (veja-se a Figura 3, croquis de Pupo; e, mais à frente, as Figuras 12 e 14, reconstituição para o presente trabalho). Costa Santos (1998), tendo feito a estrada seguir pelo vale do Proença até à barra com o Serafim, não contempla passagem pela atual Paula Bueno, nem pela que é, ainda hoje, em trechos mais afastados, a "estrada de Mogi".

Vê-se, portanto, que o que levou Costa Santos a afirmar, a partir da leitura de Daunt (1904), que a estrada dos Goiases seguia pelo vale do Proença, foi: 1) o fato de acreditar ser o local do pouso - o "lugar depois conhecido por Campinas Velhas", do texto - o local da "aguada que serve de logradouro público", embaixo do atual viaduto do Laurão; 2) o fato de acreditar que a "frente da chácara hoje [1879] do Dr. Sampaio Peixoto" encontrava-se no vale. Ora, ambos esses pressupostos são equívocos: o pouso, embora relacionado com a referida aguada, localizava-se em cota superior, no cruzamento das atuais avenida Moraes Sales e rua ltu ${ }^{84}$, sendo existentes afirmações em contrário somente desde 1944; e a chácara do dr. Sampaio Peixoto tinha frente para a atual rua Coronel Quirino, como demonstram os documentos acima. Baseado nesses pressupostos, Costa Santos (1998) faz seguir o caminho pelo vale do Proença até à barra com "outro rio que vem da vila", e aí prosseguir pelo vale do Anhumas, formado da junção desses dois, afastando-se da descrição legada pelo dr. Ricardo Daunt em 1879 (DAUNT, 1904), único documento que the servia de guia. 
Contrariamente à leitura de Santos (1998) - tributária de pressupostos que, ainda quando amparados por parte da bibliografia recente (como no caso da localização do pouso), revelam-se falhos -, a descrição de Daunt (1904) não indica trajeto pelo vale do Proença. Afirma que o caminho passava pelo pouso (atual cruzamento da avenida Moraes Sales e rua ltu), depois pela rua Coronel Quirino e, depois, pela atual rua Paula Bueno. Assim, a descrição de Daunt (1904), à vista dos argumentos e documentos apresentados, não apenas não sustenta a leitura que dela fez Santos (1998), como, por outro lado, condiz com o croquis apresentado por Pupo (1969) e com o traçado a que chega o presente trabalho - baseado em foto-interpretação -, que passamos agora a apresentar.

Aplicações da foto-interpretação e critérios utilizados

Devo ao prof. Dr. Gustavo Neves da Rocha Filho o contato com a foto-interpretação de fotografias aéreas como recurso de pesquisa. Não é sem interesse registrarmos aqui algumas das características e potencialidades desse recurso.

Os levantamentos aéreos em questão constituem conjuntos de fotografias aéreas verticais, tiradas ao longo de faixas contínuas e com uma sobreposição de 50 a 60 \% entre duas chapas sucessivas. Tal sobreposição permite, vistos pares de fotografias consecutivas no estereoscópio, ter a imagem em 3D do território ${ }^{85}$. Nessa visão 3D, as dimensões verticais (relevo) aparecem aumentadas dez vezes em relação às dimensões horizontais - com o que a percepção da morfologia do território (relevo) torna-se, além de imediata, particularmente precisa.

A escala das chapas dos levantamentos aéreos é variável; no geral, é tal que permite identificar, por exemplo, residências, quintais e árvores individualmente.

Para fins de planejamento urbano, a foto-interpretação tem facultado, entre outros ${ }^{86}$ : identificar, nas zonas rurais, as áreas ocupadas por campos, florestas, e as áreas cultivadas, bem como, nestas, as diferentes culturas praticadas ${ }^{87}$; estimar a idade aproximada dessas culturas ${ }^{88}$ e medir, com precisão, a área de cada qual. Nas ruas e estradas, avaliar a densidade de tráfego de cada uma ${ }^{89}$. Nos aglomerados urbanos, diferenciar as unidades residenciais daquelas casas que abrigam comércio e serviços ${ }^{90}$.

A geometria dos traçados permite, de pronto, diferenciar ferrovias e estradas entre si. Unidades comerciais localizadas ao longo das estradas são denunciadas pela existência de caminhos peatonais que convergem para esses pontos, os quais desse modo aparecem como o centro de um "asterisco".

A partir da análise de um levantamento aéreo, ainda que relativamente recente, também se pode conhecer muito da história da evolução urbana de uma localidade: a diferença de tonalidades dos telhados de diferentes unidades
85. O estereoscópio é um aparelho ótico em que cada uma das duas fotografias de um par é vista por cada um dos olhos, separadamente. Embora as fotografias possam ser ampliadas em maiores dimensões e em diferentes formatos (é usual veremse imagens aéreas ampliadas em formato de posters, penduradas nas paredes de órgãos públicos) as chapas destinadas a uso no estereoscópio são quadradas, e de dimensões menores; as utilizadas nesse trabalho medem $18 \times 18 \mathrm{~cm}$. As foto-cartas - mapas resultantes da mosaicagem de diversas imagens de um levantamento aéreo -, como as utilizadas por Costa Santos (1998, p. 68 nota 109), não se prestam à visão estereoscópica, que depende das imagens soltas.

86. Cf. comentários em aula do prof. Dr. Gustavo Neves da Rocha Filho, que desenvolveu, desde os anos 1960, dezenas de planos diretores para cidades de São Paulo, sempre com uso de foto-interpretação para o reconhecimento e mapeamento iniciais. Acerca dos usos da foto-interpretação nesse domínio, veja-se:A. Burger, Photographies aériennes et aménagement du territoire (BURGER, 1952).

87. Cada cultura (café, laranja etc.) apresenta uma distância de plantio entre cada indivíduo (planta) que lhe é característica, o que, a par de outros aspectos, permite identificar as diferentes culturas.

88.A diferença, por exemplo, entre as copas de um pé de café novo e um velho são reconhecíveis nas fotografias aéreas, onde o velho (copa menos viçosa) aparecerá como um ponto menor que o do 
novo, correspondendo cafezais velhos e novos a padronagens características.

89. Uma via asfaltada torna-se mais e mais lisa quanto mais trafegada, o que interfere na reflexividade de sua superfície. $\mathrm{Na}$ fotografia aérea, aparecerá tanto mais escura quanto mais tráfego tenha acumulado.

90. Dado que (ao menos nas cidades pequenas $\mathrm{e}$ médias) as unidades residenciais apresentam quintais arborizados, ao passo que as comerciais/ de serviços não.

91. Sussmann (1961, p 11-15).

92. Idem, p. 13-14

93. Cf. depoimento do prof. Dr. Gustavo Neves da Rocha Filho. permite aquilatar a idade relativa dos diferentes edifícios; não só estradas, mas mesmo trilhas peatonais, são perfeitamente visíveis, e assim permanecem mesmo quando já em desuso. Uma antiga estrada ou trilha permanece muitas vezes visível, mesmo quando o território que atravessava vem a ser loteado, sem que o novo arruamento tome conhecimento do traçado da antiga via - a continuidade de segmentos subsistentes dessa via é facilmente perceptível na imagem aérea, e trechos do antigo percurso permanecem visíveis nas áreas não-edificadas das quadras.

Numa linha específica (trilha), quando ocorre trânsito continuado (pedestres, animais), o terreno fica impregnado de uma diferença de compacidade e umidade que permanece por tempo indeterminado, mesmo depois de interrompido o tráfego. No caso de campos, a vegetação que cresce numa trilha abandonada é mais rala que a do entorno. Essa diferença não é sensível numa visão no nível do chão, mas, nas fotografias aéreas, a antiga trilha é denunciada como uma linha mais clara que o tom do entorno.

Devido à fotografia aérea os americanos fizeram ressurgir as civilizações pré-colombianas, e os russos as fabulosas cidades destruídas por Gengis Khan na região do mar de Aral [...]. Na Indochina, as muralhas das antigas cidades foram descobertas pelas árvores. E no Egito encontrou-se um sistema de irrigação da época dos Ptolomeus ${ }^{91}$.

As razões são análogas às que justificam marcas de antigas trilhas:

A vegetação toma um grande desenvolvimento quando suas raízes encontram sob o solo antigos fossos ou canais, que constituem reservas de umidade para sua subsistência. Quando ao contrário a terra encobre antigas ruas, praças ou muralha, as plantas não encontrando alimentos secam e morrem. Em qualquer dos casos, os pesquisadores descobrem manchas, círculos e faixas de coloração particulares, que thes revelam o trabalho dos homens de épocas passadas ${ }^{92}$

Vale também apontar ${ }^{93}$ que, quando das démarches para 0 redescobrimento da antiga calçada do Lorena (primeira via pavimentada entre São Paulo e o litoral, de fins do século XVIIII, foi possível reconhecer o traçado da dita estrada, há muito abandonada e completamente coberta pela floresta tropical da Serra do Mar, a partir de fotografias aéreas: como nenhuma árvore de grande porte cresceu por sobre a antiga estrada, havia, no tapete formado pelas copas das árvores, uma "linha de fratura", visível nas fotografias aéreas.

O potencial das fotografias aéreas para o reconhecimento de intervenções humanas ancestrais, e em particular no de antigas trilhas, é, portanto, conhecido e utilizado.

Uma dada marca em uma imagem aérea pode corresponder a fatos ou objetos diversos, de modo que a foto-interpretação é, justamente, uma "interpretação", dependente de conhecimento prévio sobre as características do objeto a ser identificado e de suas possíveis correspondências numa imagem aérea. No nosso caso, esse conhecimento consiste: 1) nas indicações que, sobre o trajeto da antiga estrada dos Goiases, pôde-se haurir da documentação e da 
historiografia local (indicações que, em sua maior parte, já foram elencadas ao longo do item anterior); 2) no conhecimento de que o solo guarda, por tempo indeterminado, a "memória" da alteração de compacidade gerada pelo trânsito ao longo de uma trilha, o que determina alteração do porte de vegetação e, assim, que a dita trilha, mesmo quando abandonada há séculos, aparece na imagem aérea, nos terrenos não-edificados, como uma linha de coloração mais clara que a do entorno, como afirmado logo acima; 3) no pressuposto de que os antigos caminhos bandeirantes, a exemplo das trilhas indígenas, tendiam a seguir pelas cristas dos relevos (espigões).

Uma vez alertados - conforme afirmações que já reproduzimos em item anterior, e contrariamente a um senso difundido - de que nas rotas bandeirantes os cursos d'água eram obstáculos a serem vencidos e não vias a serem aproveitadas, a preferência entre as alternativas restantes, em meia-encosta ou na linha de espigão, deve recair sobre esta última, que evita um caminho penso e permite mais completo domínio visual sobre o território que se desbravava.

p princípio de que os antigos caminhos tendiam a seguir especificamente pelas cristas dos relevos (espigões) é afirmação respaldada na larga experiência acumulada pelo prof. dr. Gustavo Neves da Rocha Filho em pesquisas reconstitutivas com uso de foto-interpretação.

No âmbito da cidade de São Paulo, podemos invocar algumas evidências em apoio desse princípio. Como se sabe, antigos caminhos que demandavam a vila serviram de eixos para o crescimento urbano experimentado sobretudo desde o último quartel do século XIX. Em regra, tem-se que as vias, algumas mais antigas que outras, procuravam aproveitar, na medida do possível, os espigões, evitando os terrenos alagadiços, ocupados paulatinamente pelos loteamentos que foram sendo "pendurados" ao longo desses eixos. Um exemplo dessas vias de espigão que serviram de eixo de crescimento corresponde à atual avenida da Liberdade. Outras duas dessas vias - tão ou mais antigas que o próprio colégio jesuíta, origem da cidade - são o caminho que, desde o triângulo, demandava a antiga aldeia dos Pinheiros

[...] seguindo os eixos das atuais ruas José Bonifácio, Ladeira do Ouvidor, atravessando o Anhangabaú, subindo pelas ruas Quirino de Andrade, rua da Consolação, Bela Cintra, avenida Rebouças, rua dos Pinheiros, Butantã, cruzando o rio Pinheiros onde hoje se encontra a ponte Eusébio Matoso ${ }^{94}$

e aquele que, derivando desse outro na altura do espigão da Paulista, seguia "pelas atuais avenida Doutor Arnaldo e Heitor Penteado", via conhecida no início do século XX como "caminho do Araçá" quinhentistas $^{90}$, e o primeiro seria, possivelmente, parte de trilha indígena anterior à chegada dos jesuítas ${ }^{97}$.

Numa escala regional, Pierre Mombeig (1984, p. 35-42, 137) já fez notar como as primitivas trilhas e, a seguir, rodovias e ferrovias de penetração do Oeste do estado seguiam pelos espigões.

As marcas que na imagem aérea é possível verificar da existência de antigas trilhas, mesmo quando abandonadas há séculos, e a percepção não
94. Rocha Filho (1994, p.

9).

95. Idem. Ibidem

96. Rocha Filho (1994)

97. Gonçalves (1998, p 44-45 e passim). 
98. Em 1962 foi encomendado um primeiro levantamento aéreo completo de todo o estado de São Paulo. apenas imediata mas particularmente destacada da morfologia (relevo) do território, na imagem 3D que se obtém com a fusão estereoscópica de pares dessas imagens - informações essas últimas particularmente relevantes frente ao princípio de que os antigos caminhos tendiam a seguir pelas cristas do relevo-, são fatores capitais que recomendam a técnica da foto-interpretação, nas palavras do prof. dr. Gustavo Neves da Rocha Filho, como "o método apropriado" para a pesquisa do trajeto de antigas vias.

O levantamento aéreo utilizado para a foto-interpretação realizada

Neste trabalho utilizamos, para a foto-interpretação, em busca do reconhecimento do traçado da antiga estrada dos Goiases, um jogo de fotografias verticais de levantamento aéreo da região do município de Campinas datado de junho de 1940. Como esse conjunto é pouco conhecido; como seguramente apresenta vantagens para a pesquisa histórica com relação aos conhecidos levantamentos de $1962^{98}$ e outros posteriores; e, finalmente, visto que não temos garantia da existência dos negativos originais, julgamos de interesse registrar breve nota sobre esse material.

Segundo informação colhida no IGC, as empresas que fazem levantamentos aerofotogramétricos são obrigadas por lei federal a arquivar os negativos indefinidamente, ou comunicar formalmente a destruição de qualquer dos originais, mantendo o fato em arquivo. Segundo a mesma fonte, a única empresa que atuou no estado de São Paulo em período tão recuado quanto junho de 1940 é a ENFA (Empresa Nacional de Fotografia Aérea), cujo acervo foi sucessivamente incorporado pela VASP, Aerofoto, e BASE, herdando igualmente cada uma dessas empresas, sucessivamente, as obrigações de guarda desse material, segundo a referida lei. Em contato telefônico, essa empresa informou não possuir registro do levantamento em causa. Os negativos podem estar em posse do Ministério da Agricultura, executor do levantamento, a julgar pelo selo de identificação das fotografias, como adiante explicitado.

O jogo de fotografias que utilizamos encontra-se arquivado no Departamento de Documentação, Informação e Cadastro (DIDC) da Secretaria de Planejamento da Prefeitura de Campinas. Há, no verso de cada imagem, um selo (Figura 9) com o timbre "Ministério da Agricultura. DNPM. DA. Secção de Fotogrametria", daí presumindo-se ter sido o Ministério da Agricultura o órgão executor do levantamento em causa. O selo traz ainda, datilografados nos campos para tanto existentes, além dos números do filme e da chapa, altitude do vôo e local ("Campinas"), a data do levantamento - "6/1940" - e a identidade do operador - "P. Barros".

As fotografias apresentam-se no formato de $18 \times 18 \mathrm{~cm}$, em escala aproximada de 1: 16500. No DIDC se encontram 118 imagens, numeradas de 35 a 153, havendo, de boa parte delas, duas cópias, e faltando a de número 77. Essas imagens dispõem-se em faixas de 17 fotografias cada lfaixas 


\section{MINISTÉRIO DA AGRICULTURA - D.N.P.M. - D.A. SECÇÃO DE FOTOGRAMETRIA FILME 6 CHAPA 080 Local Campinas ALT. S/MAR2580 ESC. APR EM. 6 ...194.O AEROF.o.P. Barros}

Figura 9 - Ministério da Agricultura-Departamento Nacional de Produção Mineral, Selo no verso das fotos do levantamento aéreo de 1940. Fonte: Acervo digital do Departamento de Documentação, Informação e Cadastro - Secretaria de Planejamento - Prefeitura Municipal de Campinas. O verso das fotos aéreas utilizadas no presente trabalho, traz este selo informando, entre outros, a data do levantamento: "6/940" (Junho de 1940).

35-51, 52-68, 69-85, 86-102, 103-1 19, $120-136$ e 137-153). Podendo-se concluir que faltam, no conjunto existente no DIDC, além da fotografia 77 , duas faixas inteiras, com as fotografias 1-17 e 18-34. Essas duas faixas faltantes cobrem a região a Leste da mancha urbana, incluindo possivelmente o atual distrito de Souzas. As faixas dispõem-se na direção Norte-Sul, e desenvolvemse, alternadamente, no sentido Sul-Norte e Norte-Sul.

Recentemente, o DIDC procedeu à digitalização dessas imagens.

As linhas de drenagem (não necessariamente rios ou riachos) foram marcadas nas imagens aqui apresentadas, de modo a permitir um reconhecimento do relevo, mesmo na imagem 2D.

Reconstituição do traçado na área da fotografia 40

A área coberta por essa fotografia (Figura 10) é, do total da área estudada, aquela que apresenta as evidências topográficas mais contundentes para a identificação do provável trajeto da "estrada dos Goiases", segundo a norma geral de que as trilhas procuram as cristas do relevo, evitando tanto as encostas quanto os fundos de vale. De fato, nessa área se vê uma crista claramente dada - um divisor de águas, com variações de cota relativamente pequenas ao longo de sua linha, em contraste com as rampas de acentuada declividade que vão se sucedendo, ortogonalmente, à direita e à esquerda. A existência de uma 
99. A estrada de rodagem São Paulo-Campinas foi a primeira inaugurada no governo de Washington Luís Pereira de Souza que, como se sabe, notabilizar-se-ia pelo impulso dado à rede rodoviária do estado. Existe cópia da planta dessa estrada no Centro de Memória da Unicamp. Em caixas do Arquivo Municipal se encontram outros documentos a respeito, tal como lista dos convidados, e cartas e cartões de desculpas dos que não puderam comparecer, dentre as quais uma de Antônio Prado.

100.A escala das fotografias é de aproximadamente 1:16500. As esti mativas são a olho nu.

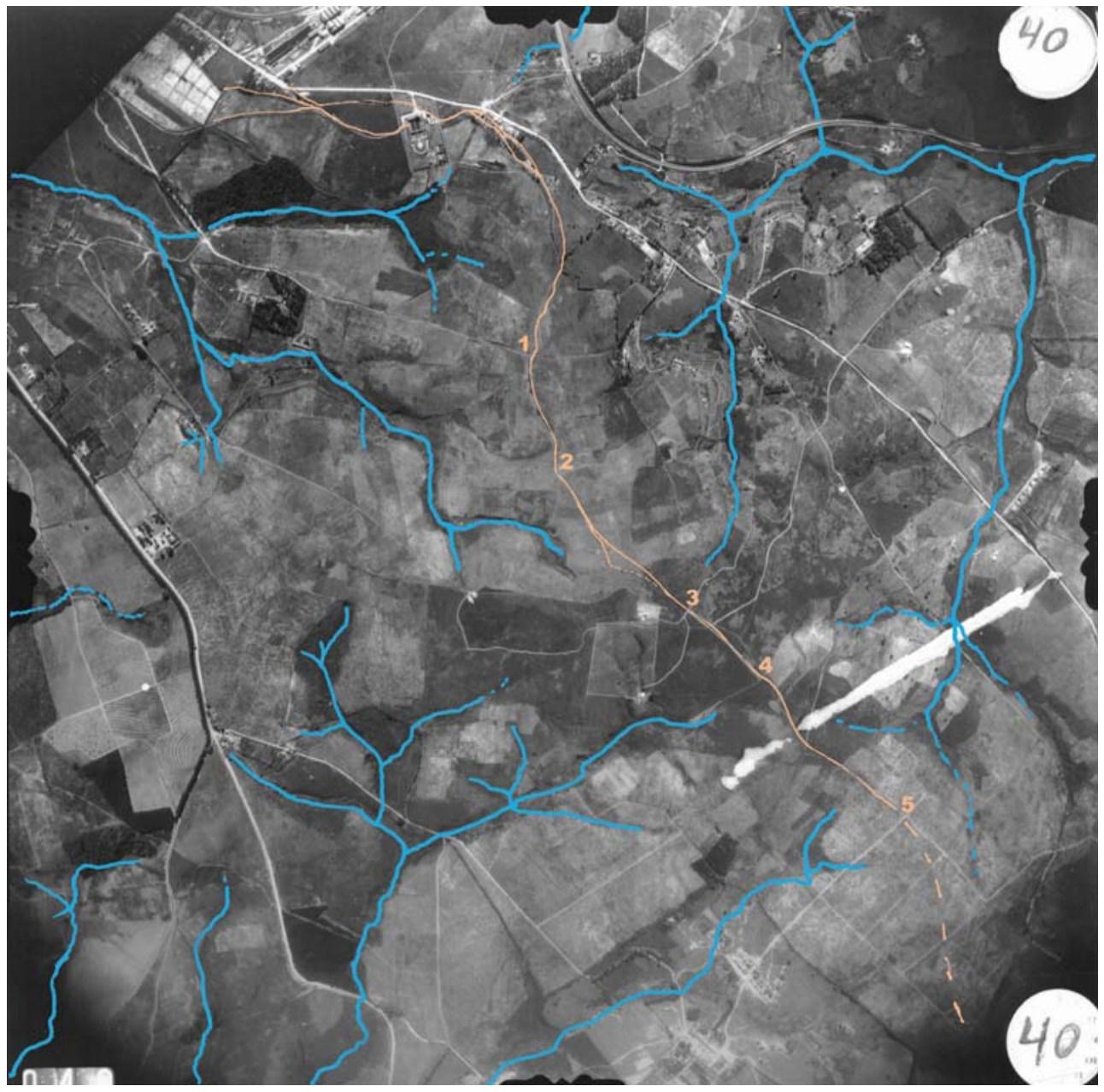

Figura 10 - Reconstituição, feita pelo autor, do traçado da estrada dos Goiases sobre a área da foto no 40 do levantamento aéreo de 1940. Ministério da Agricultura-Departamento Nacional de Produção Mineral, Levantamento aéreo de Campinas, 1940, chapa nº 40. Fotografia aérea, $18 \mathrm{~cm} \times 18 \mathrm{~cm}$. Fonte: Acervo digital do Departamento de Documentação, Informação e Cadastro - Secretaria de Planejamento - Prefeitura Municipal de Campinas.

marca, sutil, que se perde em alguns trechos, de uma trilha ao longo desse espigão, reforça a evidência de que, nesta área, este teria sido o trajeto da "estrada dos Goiases".

À esquerda da fotografia, vê-se uma estrada; trata-se da estrada de rodagem de Campinas a São Paulo inaugurada por Washington Luís em 1ํ de maio de $1921^{99}$ - onde há hoje, nesse mesmo traçado, a avenida Washington Luís.

A direita, de Sudeste a Noroeste lo Norte, na fotografia, está para cima), vê-se outra estrada. Pode-se estimar a largura da estrada da esquerda (estrada de rodagem de 1921) em pelo menos oito metros; sendo, a dessa outra à direita, metade ou menos ${ }^{100}$. $O$ trajeto dessa segunda é também mais acidentado, sugerindo tratar-se de estrada mais antiga que a anterior. Sua direção 
concorda com a indicada no registro de Luiz d'Alincourt que, vindo de São Paulo, em 1818 , cita também a transposição de talvegues (seguidos de ladeiras) no trecho desde o "rancho do Pinheiro", atual cidade de Valinhos, até à "vila de São Carlos de Campinas":

[...] próximo a ela está o rancho do Pinheiro, além do qual sobe-se uma ladeira alcantilada, que, em tempos de chuva, se torna quase impraticável, por ser de um barro muito escorregadio, e depois desta passam-se mais duas, e o vale do Coronel Luis Antônio, seguindo a estrada ao Noroeste, a Oeste-noroeste, até que enfim chega-se à vila de São Carlos de Campinas ${ }^{101}$.

A linha curva que se vê ainda mais à direita e junto do bordo superior da fotografia é a linha férrea (antiga linha da Paulista, de Campinas a Jundiaí).

A área branca junto do canto superior esquerdo da fotografia são os fundos do atual cemitério da Saudade (antigo "cemitério do Fundão"), inaugurado em 1881, sendo essa área dos fundos resultado de ampliação pouco posterior (LORETTE, 2003, p. 204).

Embora a estrada da parte superior seja menos acidentada que a da parte inferior, ambas cortam fundos de vale e talvegues (linhas de drenagem) que vão se sucedendo de um e outro lado de um espigão contínuo - uma crista do relevo, muito bem determinada, como se pôde ver na visão estereoscópica dessa área; e como o traçado das linhas de drenagem deixa perceber.

Desde o canto dos fundos do cemitério, verifica-se a existência de uma trilha, que acompanha rigorosamente essa crista do relevo, e cuja marca se perde gradualmente a partir do ponto $2^{102}$. Entre os pontos 3,4 e 5 verificase novamente a marca de uma trilha coincidente com a crista do relevo (mais marcada entre 3 e 4 , mais sutil entre 4 e 5). A partir do ponto 5, e na área de cobertura dessa fotografia, não há mais quaisquer marcas de trilha coincidindo com a crista do relevo, que segue o traçado indicado. A crista do relevo, muito claramente dada, segue numa linha contínua entre todos esses pontos, podendose afirmar que os trechos (no mais, extensos) em que, nessas fotografias de 1940, verifica-se a presença de trilhas coincidindo com essa crista claramente dada seriam remanescentes de uma única trilha, contínua, ao longo da dita crista, que outra não seria senão o próprio "caminho dos Goiases".

Reconstituição do traçado na área da fotografia 62

A seqüência do percurso, desde a área da fotografia 40, chega ao canto sudeste (inferior direito, na fotografia) do cemitério da Saudade. Não se vê nenhuma continuidade dessa trilha, nem à esquerda nem à direita desse canto, acreditando-se que o caminho da antiga estrada dos Goiases passa a atravessar a área do atual cemitério da Saudade, disposto num platô em meio à crista do relevo.

cemitério havia sido inaugurado em 1881 , "à beira da estrada para São Paulo", reunindo diferentes cemitérios então existentes, e cuja
101. D'Alincourt (1975, p. 50-51)

102. No ponto 1 , vê-se que cruza ortogonalmente outra trilha, que vem desde a parte lateral esquerda do cemitério, em alternativa de traçado que tem continuidade na área da fotografia 62 , onde será comentada. 
localização começava a conflitar com a expansão da cidade (LORETTE, 2003, p. 201, 203). A Figura 11 apresenta um croquis do engenheiro municipal, da última década do século XIX, estudando a ampliação do cemitério, que se fazia necessária por conta das epidemias de febre amarela. Nesse croquis vê-se, à direita, uma via denominada "estrada" - certamente, estrada para Jundiaí e São Paulo. Percebe-se claramente que essa "estrada" ali identificada corresponde ao caminho entre os pontos 4 e 5 da fotografia 62 (Figura 12); vê-se que esse caminho interrompe-se pouco antes do ponto 5 , havendo então um pequeno trecho que "emenda" o dito caminho com a via de acesso ao cemitério, atual avenida da Saudade, exatamente como no croquis da Figura 6 . Conclui-se que o caminho 3-4-5-6, ou, mais provavelmente, 2-4-5-6, da fotografia, corresponde

Figura 11 - Nesse croquis, feito pelo engenheiro municipal Emille Daufresne, relativo à ampliação do cemitério em fins do séc. XIX, tem-se, à direita, uma via denominada "estra$d^{\prime \prime}$. Essa via é claramente aquela marcada na foto $n^{\circ} 62$ pelos pontos 4, 5 e 6 , permitindo concluir que esse trecho 4-5-6 seria parte da estrada para São Paulo no seu traçado de fins do séc. XIX, traçado que a abertura da atual Avenida da Saudade ("Caminho do Cemitério", no croquis acima), em 1881, interrompera no ponto 5. Emille Daufresne, Esboço de ampliação do cemitério das Almas, Campinas. [189?] (LORETTE, 2003).

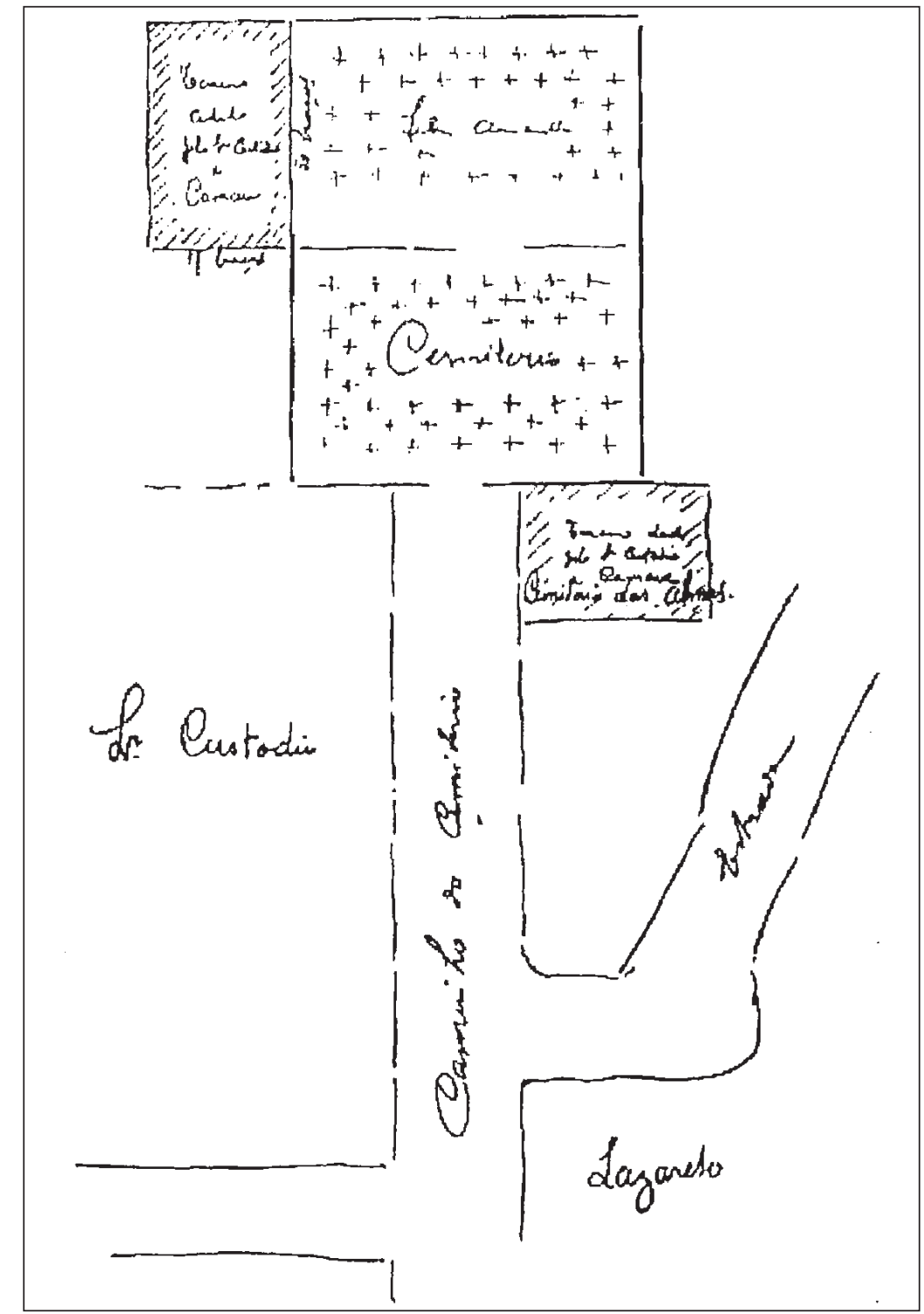

Anais do Museu Paulista.v. 14.n.2. jul.-dez. 2006. 


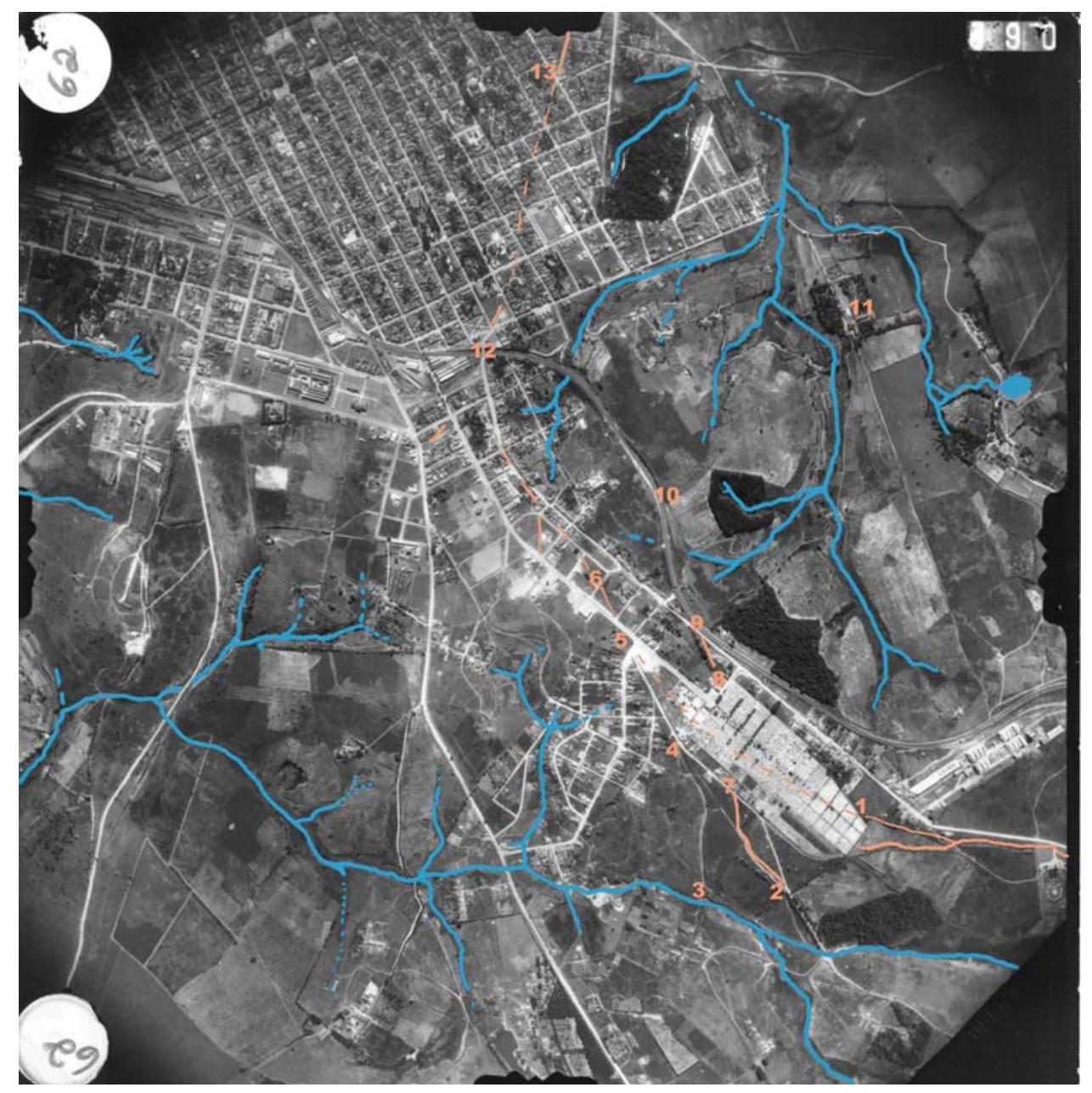

Figura 12 - Reconstituição, feita pelo autor, do traçado da estrada dos Goiases sobre a área da foło no 62 do levantamento aéreo de 1940. Ministério da Agricultura-Departamento Nacional de Produção Mineral, Levantamento aéreo de Campinas, 1940, chapa no 62. Fotografia aérea, $18 \mathrm{~cm} \times 18 \mathrm{~cm}$. Fonte: Acervo digital do Departamento de Documentação, Informação e Cadastro - Secretaria de Planejamento - Prefeitura Municipal de Campinas.

a um trecho do traçado que a estrada para São Paulo apresentava em fins do século XIX, e que a abertura do caminho de acesso ao novo cemitério latual avenida da Saudade) viera interromper no ponto 5.

Que esse caminho tenha sido parte do traçado de estrada para São Paulo na última década do século XIX não significa que tenha sido parte do traçado da estrada dos Goiases. Esse caminho 6-5-4, tanto pela sua seqüência por 3, quanto por 2, irá cruzar o traçado que se evidencia como sendo o da antiga estrada dos Goiases, no ponto 1 da fotografia 40. Entretanto, a seqüência natural - desde aquele ponto 1 da fotografia 40 até à redondeza do cemitério - dá-se, ao longo da cumeeira (crista) do relevo, chegando ao canto do cemitério, no ponto 1 dessa fotografia 62 ao passo que o percurso 6-5-4-2 (ou 6-5-4-3) 
103. Curiosamente, o traçado de 2-7-8-9 parece concordar, a partir de 9 com o traçado da antiga linha da Paulista (inaugurada em 1872), entre os pontos 9 e 10 . Posto que nesse trecho a via férrea dispõe-se sobre um aterro, ao modo de uma ponte por sobre um talvegue, poder-se-ia pensar que esse trajeto 2-7-8-9-10 tenha sido um atalho tomado para atingir a então estrada para São Paulo no ponto 2, utilizando-se parte do traçado da via férrea. atravessa um talvegue acentuado. Assim, o caminho 6-5-4-2 (ou 6-5-4-3), pela lateral esquerda do cemitério, corresponderia a trecho de um traçado posterior ou derivação secundária. Considerando-se a seqüência 6-5-4-7, seria não mais que um desvio imposto pela construção mesma do cemitério, em 1881 . Enquanto o traçado mais antigo, o da estrada dos Goiases, atravessaria o atual cemitério, entre os pontos 1 e 5 da fotografia 62.

É preciso ainda referir que se nota o traçado 2-7-8-9. O caminho que se vê entre os pontos 2 e 7 interrompe-se nesse ponto de encontro, obliquamente à lateral esquerda do cemitério, reaparecendo no ponto 8 , na lateral direita do cemitério. Entre 7 e 8 , pelo meio do cemitério, notam-se marcas desse mesmo traçado. Não ficou esclarecida a natureza ou seqüência desse trajeto 2-7-8-9: entre 9 e 13 há um profundo talvegue, e nenhuma marca de possível trajeto; a atual rua da Abolição, pela qual se liga 9 a 12, é posterior; e não apresenta concordância com o traçado até $9^{103}$.

O traçado da estrada dos Goiases atravessa a área do atual cemitério entre os pontos 1 e 5 , e, seguindo sempre pela crista do relevo (neste trecho mais larga que no da área da fotografia 40), seguiria pelos pontos 12 e 13.

O ponto 11 indica a antiga sede da fazenda Paraíso, objeto central do trabalho de Costa Santos (1998), na cabeceira do vale do Proença, vale onde o mesmo autor localiza o trajeto do caminho dos Goiases, em hipótese que já comentamos.

O ponto 12 marca a "ponte Preta", hoje um bem tombado, e que data de pouco depois da instalação da via férrea, com pequeno movimento de terra. $O$ ponto em que a estrada dos Goiases teria cruzado esse traçado da futura ferrovia, a julgar-se pelo relevo, corresponde a esse mesmo ponto 12, pouco mais ou menos.

A partir do ponto 13, o traçado da antiga estrada corresponde a uma rua ainda hoje existente (rua Itu), de pequena extensão, e disposta obliquamente em meio ao traçado em "tabuleiro de xadrez". A direção apontada por essa rua - singularmente oblíqua em meio ao "tabuleiro de xadrez" que the seria posterior - orienta-se para o ponto 12, havendo igualmente algumas marcas, pelo meio das quadras, entre os pontos 12 e 13.

Reconstituição do traçado na área da fotografia 60: tramos que denunciam o local do antigo pouso e refutação de passagem original pelo largo de Santa Cruz

Nesta fotografia (Figura 13), o trecho entre os pontos $\mathrm{O}$ e 2 corresponde à totalidade da atual rua ltu, de apenas duas quadras, e que, como referimos acima, seria um trecho da antiga estrada dos Goiases que terminou permanecendo, disposto obliquamente em meio ao "tabuleiro de xadrez" que the seria posterior. Ao meio, no ponto l, a rua ltu cruza a atual avenida Moraes 


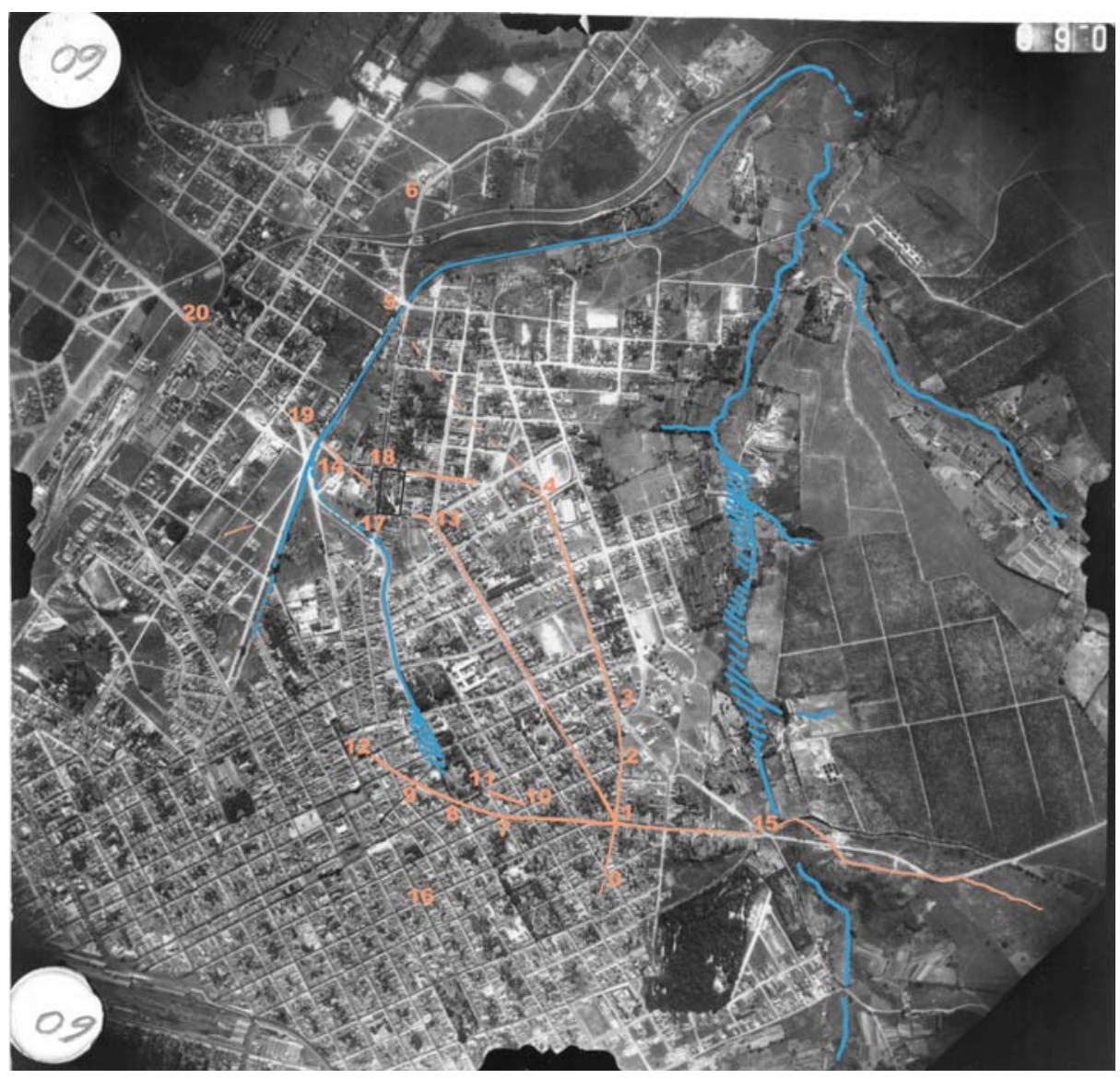

104. Pupo (1969, p. 115); Goulart (1983)

Figura 13 - Reconstituição, feita pelo autor, do traçado da estrada dos Goiases sobre a área da foto nº 60 do levantamento aéreo de 1940. Indicação dos tramos que, convergindo no ponto 1, denunciam o local do "pouso das campinas". Ministério da AgriculturaDepartamento Nacional de Produção Mineral, Levantamento aéreo de Campinas, 1940, chapa $\mathrm{n}^{\circ}$ 60. Fotografia aérea, $18 \mathrm{~cm} \times 18 \mathrm{~cm}$. Fonte: Acervo digital do Departamento de Documentação, Informação e Cadastro - Secretaria de Planejamento - Prefeitura Municipal de Campinas.

Sales, antigo "caminho para Campinas Velhas" 104, cruzamento que corresponderia, segundo Pupo (1969, p. 47; aqui, Figura 3), à localização do "pouso das Campinas", ponto de início do povoamento da cidade.

Verifica-se, em acordo com essa afirmação, que o pouso das Campinas se encontrava no atual cruzamento da rua ltu e avenida Moraes Sales; e que, para esse ponto, convergem três caminhos - na fotografia, os caminhos de 1 a 12, 1 a 13, e 1 a 15, todos anteriores ao século XIX, segundo as evidências e conforme adiante especificado -, além da própria estrada dos Goiases, rumo a norte e a sul - 1-0 e 1-2 na fotografia. Resulta, assim, que o ponto 1 fica marcado como ponto de convergência de cinco tramos, como um asterisco, o que é sabidamente uma situação típica de pontos de comércio - e pousos. 
ponto 12 marca o local onde foi construída a capela provisória, 106. Cf. Pupo (1969), p 115 quando da ereção do bairro em freguesia, em 1774. O antigo pouso teria originado o "bairro das Campinas Velhas", ao passo que a cidade se desenvolveu ao redor do ponto 12 .

A referência de Octavio (1922, p. 11 ), de que a ligação entre as "Campinas Velhas" (arredores do ponto 1) e o núcleo da futura cidade (ponto 12) se dava "por um caminho que é hoje a rua Moraes Sales", é o que leva Bergó (1944) a apresentar o traçado de ligação desde o antigo pouso até o novo centro, passando pela atual Moraes Sales e, a seguir, fazendo um ângulo de 90, pela atual rua Barão de Jaguara (1-16-12, na fotografia; vide também Figura 5). Como já comentamos, essa proposição toma por base o trajeto de ruas que somente vieram a existir em tempo muito posterior ao dessa ligação, não sendo aceitável, nesse caso, o trajeto por dois segmentos em ângulo reto. Mesmo sendo fato que a atual avenida Moraes Sales chamou-se, a um tempo, rua "que vai para Campinas Velhas" ${ }^{105}$, entretanto apenas um trecho do seu curso atual corresponde ao caminho original entre os pontos 1 e 12, cujo traçado passamos a considerar.

Vê-se que o antigo "beco do Rodovalho" (8-9 na fotografia) aparece alinhado entre os pontos 1 e 12. Na quadra adjacente, notam-se marcas nesse mesmo alinhamento (7-8, na fotografia). Ainda hoje existe esse beco, com apenas seis metros de largura, e disposto em nível, evitando a baixada da atual praça Carlos Gomes (visível na fotografia, com um dos cantos junto do ponto 8), que ainda era um grande lodaçal em fins do século XIX. Assim, pode-se tomar por hipótese que o percurso original entre o antigo pouso e a capela seria: 1-7-8-9-12. Podendo-se ainda, alternativamente, estudar o traçado 1-10-1 1-12 (em vista de certa marca entre 10 e 11 , e notando-se o perfeito alinhamento desses quatro pontos).

Apenas um pequeno trecho da atual avenida Moraes Sales, que desde o ponto 1 aponta em direção ao ponto 7 , pertence a esse traçado. $\bigcirc$ restante do trajeto original cede lugar ao arruamento em tabuleiro de xadrez da cidade.

Lembre-se, nesse sentido, que a atual Moraes Sales não foi a única "rua que vai para Campinas Velhas"; também as suas imediatas, as atuais ruas Ferreira Penteado (paralela à Moraes Sales pelo ponto 7, na fotografia) e Conceição (idem, pelo ponto 8), chamaram-se, em tempo, rua "que vai para Campinas Velhas" e "rua nova que vai para a Campinas Velha"106. $\bigcirc$ que nos leva a inferir que o antigo caminho tenha sido, com o avanço gradativo dos arruamentos, sucessivamente emendado com trechos da rua Conceição (no ponto 8), depois com a Ferreira Penteado (ponto 7), até à emenda com a atual Moraes Sales, que de início herdou-lhe o nome. Eis o que cabia considerar sobre o caminho 1-12.

C caminho de 1 a 15 é o trecho inicial da ligação até ao Arraial dos Souzas. Tal ligação remonta certamente ao século XVIII. Com efeito, o povoamento da localidade dos Souzas, antigo "bairro da ponte", ou "da ponte do Atibaia", aspecto particular do povoamento de toda a região com a abertura 
da estrada (1722), seria ainda anterior à ereção do bairro das Campinas em freguesia (1774), segundo indicação de Jolumá Brito ${ }^{107}$.

$\bigcirc$ ponto 15 marca o local da aguada de que se servia o pouso. Assim, independentemente de sua seqüência até o antigo bairro da ponte (Souzas), o caminho 1-15 já teria existido desde a criação do pouso.

A bibliografia ${ }^{108}$ aponta tanto o ponto 12, onde seria construída a igreja, quanto o ponto 15, local da aguada de que se servia o pouso, como correspondendo a dois dos três campinhos que davam nome à redondeza. Os caminhos de 1 a 12 e de 1 a 15 são também, portanto, de ligação do pouso das Campinas, à beira da estrada dos Goiases, com dois dos três campinhos a que o então bairro das Campinas do Mato Grosso de Jundiaí devia o seu nome; o caminho 1-13, pela atual avenida Júlio de Mesquita, seria de ligação do pouso das Campinas, no ponto 1, com o terceiro dos ditos campinhos. Além disso, tal como o caminho de 1 a 15 corresponde ao trecho inicial da ligação do pouso das Campinas com o bairro dos Souzas, o caminho de 1 a 13 corresponderia ao trecho inicial de uma derivação da estrada dos Goiases, pela qual o viajante, vindo de São Paulo e Jundiaí e atingindo o pouso das Campinas, nesse ponto, tomaria o rumo da região de Limeira e Piracicaba. Finalmente, o caminho de 1 a 13 liga o local do pouso das Campinas, no cruzamento das atuais avenida Moraes Sales e rua ltu, com um segundo pouso, que existiu em algum ponto da área delimitada pelo polígono 13-17-14-18, em que se inclui a atual praça XV de Novembro (destacada em preto na fotografia 60), anteriormente largo de Santa Cruz.

Dessa tripla natureza do caminho 1-13, o aspecto mais antigo le que portanto poderia ter sido aquele em função do qual primeiramente deu-se o dito caminho) seria o de ligação do pouso das Campinas (no ponto 1) com o terceiro dos três campinhos.

A precisa localização dessas Campinas, ou "campinhos", permanece indefinida. Até onde pudemos averiguar, a única fonte primária em que se faz referência a eles é a carta de sesmaria já referida, em que fica dito apenas da existência de três campinhos "no lugar a que chamam campinhos", "em distância de quatro léguas, com pouca diferença", da barranca do rio Atibaia ${ }^{109}$. Celso Maria de Mello Pupo dá, em planta, uma indicação da possível localização desses três campinhos, na figura em que apresenta o traçado esquemático do caminho dos Goiases, e que reproduzimos antes (Figura 3) - "indicação supositícia", como afirma o próprio autor, que não chega a registrar as referências dos fundamentos das suposições adotadas, verificando-se apenas que teria tomado por norma uma localização nas partes baixas dos terrenos, junto das margens de rios ou córregos.

Todos os autores consultados concordam em que a localização de um dos campinhos seria à beira do córrego do Proença, nas redondezas do ponto por sobre o qual passa hoje o viaduto do Laurão (Foto 62, n. 15), eventualmente se estendendo até pouco mais ao sul, no ponto em que hoje está o estádio do Guarani ${ }^{110}$.
107." [...] solicitei o tombamento de duas capellinhas na vizinha localidade de Sousas que, pelas contas dos historiadores que deram origem de Campinas a realização de sua primeira missa em 14 de Julho de 1774 - essa antiga ponte doAtibaia foi fundada antes de Campinas[sic]."Texto de crônica radiofônica,por Jolumá Brito (BRITO, 1980).

108. Cf. adiante especificado.

109. Carta de sesmaria,publicada em São Paulo (1921, p. 528), parcialmente transcrita em Campos Jr. (1952, p. 7).

110. Cf. Pupo (1969, p. 47); Bittencourt (1990, planta no v. 2); Lapa (1996, p.65). 
111. Ver Daunt (1904, p.123). Secundado, entre outros, por Duarte (1904) e Lapa (1996, p. 65).

112.A indicação consta de uma das plantas no volume anexo, volume que, como referido, não se encontra em todos os acervos que dispõem da obra, tendo sido encontrado em exemplar de defesa (BITTENCOURT, 1990), no Centro de Apoio à Pesquisa em História (CAPH) da FFLCH-USP.

113. Octavio (1908)
É também recorrente a referência à localização de um segundo dos campinhos "no sítio hoje [1879] occupado pela cadêa e a Matriz Velha, ou de Santa Cruz"111, ou seja, na atual praça Bento Quirino (retângulo alongado, junto do ponto 12, na fotografia 60). Apenas Celso Maria de Mello Pupo, no referido esquema (Figura 3), pareceria divergir ligeiramente dessa afirmativa, localizando este segundo campinho não na praça, em cota superior, mas no ponto correspondente junto às margens do córrego do Tanquinho, a cerca de 150 metros da praça. Entretanto, que a região da atual praça Bento Quirino tenha sido parte desse segundo campinho parece muito provável, uma vez que, com isso, explica-se o ter sido ali o local escolhido para a ereção da igreja, quando do processo para a criação da freguesia, evitando que os sitiantes da região do bairro do Mato Grosso tivessem de dirigir-se até Jundiaí para cumprir as obrigações religiosas e os enterros. Escolha que, de outro modo, seria de difícil justificativa, posto que tal ponto estava afastado da estrada dos Goiases cerca de 700 metros e, à época, completamente desocupado, segundo se depreende do trabalho do próprio Pupo (1969). De todo modo, nada impediria pensar que esse campinho se estendesse desde a região da atual praça Bento Quirino até à baixada do córrego do Tanquinho.

As afirmações quanto ao local do terceiro campinho não têm a mesma recorrência ou densidade. Bittencourt (1990) 112, secundado por Lapa (1996, p. 65) localiza o terceiro campinho no antigo largo de Santa Cruz (entre os pontos $13,14,17$ e 18 da fotografia), o que não se justifica, derivando certamente de tentar fazer corresponder os campinhos ao local dos supostos núcleos iniciais de povoamento apontados por Octavio (1922). Celso Maria de Mello Pupo, em sua proposta supositícia, indica local à margem esquerda do córrego das Anhumas, ou do Barbosa (atual avenida Orozimbo Maia), pouco a sul da atual avenida Brasil (cf. a legenda do canto inferior direito da Figura 3). Essa localização não deixa de estar junto de um caminho cujo trecho inicial era 1-13, e que, como veremos, seguia por 14. Por outro lado, a localização sugerida por Pupo diria respeito não só à região à margem esquerda, mas também à área imediata, na margem oposta - pois é despropositado pensar que, a dada altura da várzea de um rio, havendo campos em um dos lados, não os houvesse do outro, quando, como é o caso, tem-se de ambos os lados os mesmos terrenos, da mesma várzea, numa única cota. Nesse caso, o caminho 1-13-14 teria atingido esse terceiro campinho já no próprio ponto 14. As indicações existentes concordam, portanto, com a hipótese de que o caminho 1-13 ligasse o pouso (ponto 1) a um dos campinhos.

Sabe-se também que, em algum ponto do polígono 13-17-14-18 da fotografia 60 , houve um pouso.

Quando Saint-Hilaire visita Campinas, em 1919, vindo de Mogi, abriga-se à entrada da cidade, num "pouso real", no largo de Santa Cruz (atual praça XV de Novembro). Sabemos que esse pouso "foi demolido em 1870 (resol. do Gov. Prov. N. 35 de 2 de abril de 1868)"113. Desde quando teria existido, entretanto, não pudemos precisar a data. Sabe-se que esses "pousos 
reais", de construção mais sólida que os particulares, foram obra de melhoria encetada pelo governo de D. João VI - e assim sendo, o "pouso real" do largo de Santa Cruz, em que Saint-Hilaire se abriga em 1819, teria sido construído em alguma data a partir de 1808. Nada impede, entretanto, que, antes de se ter tornado um "pouso real", já por ali houvesse um pouso mais rudimentar.

Pensar que no atual Largo de Santa Cruz tenha havido um pouso já antes de 1808 faria particularmente sentido, caso se admita ter sido ali, ou junto dali, a localização de uma das três Campinas, prezadas pela boa pastagem que ofereciam às tropas, em meio ao "mato grosso" que, malgrado a vegetação exuberante, ou justamente por conta dela, era de pouco préstimo para a alimentação das bestas. Se, no caso do segundo campinho, Celso Maria de Mello Pupo apontava uma localização junto ao córrego do Tanquinho, e se parecia, entretanto, necessário admitir que uma região mais alta tenha participado de dito campinho, de modo análogo ter-se-ia margem, no caso da localização sugerida por Pupo para esse terceiro campinho (cf. Figura 3), para pensar-se numa localização que inclua a atual praça XV de Novembro em cota mais elevada. Basta, entretanto, admitir que esse campinho tenha chegado a ocupar a várzea nessa outra margem (junto do ponto 14 da fotografia 60), para que a localização de um pouso na atual praça XV de Novembro seja estratégica em relação às cobiçadas pastagens oferecidas pelos campinhos. Como vimos, o ponto indicado por Pupo deve ser considerado extensivo à área correspondente na margem oposta. Assim, se houve indicativos históricos que tenham levado Pupo a sugerir a particular localização para esse terceiro campinho, essas indicações não deixariam de concorrer também para um entendimento de que esse campinho tenha ocupado a área do ponto 14 da fotografia 60. O que é suficiente para tornar a localização de um pouso na atual praça XV de Novembro interessante do ponto de vista de acesso a esse campinho; e, neste caso, dar suporte à hipótese de que ali tenha havido um pouso ainda antes do "pouso real" que Saint-Hilaire conhece em 1819.

Finalmente, o caminho 1-13 ter-se-ia dado, também, como trecho inicial de uma derivação da estrada dos Goiases, a partir do pouso das Campinas e rumo à região de Limeira.

Nesse sentido, sabemos que o início da atual avenida Brasil era a "saída para Limeira", conforme documento da Câmara, de 1848, verificando-se, ao mesmo tempo, que o traçado da atual avenida Brasil ( 1 9-20 e além, na fotografia 60) coloca-se como continuidade do traçado 1-13-14, havendo, junto do ponto 14 da fotografia, marca de uma tal continuidade, em direção ao ponto 13.

documento de 1848 a que nos referimos é o relatório apresentado à Câmara por uma comissão encarregada de, pela primeira vez, dar nomes oficiais às ruas da vila"14. A primeira das ruas "de Norte a Sul, do nascente ao poente" é "a rua que começa na esquina da chácara do finado capitão Raphael de Oliveira Cardozo e vai sahir atrás da capella de Santa Cruz e se prolonga até a ponte do caminho que vai para Limeira: Rua de S. Cruz" ${ }^{115}$. Em planta da cidade, levantada em 1916, a atual avenida Brasil mantinha o nome de "Santa Cruz", e ainda hoje
114.Transcrito em Duarte (1904).

115. Duarte (1904, p. 142). 
116. É o trajeto indicado no esquema de Pupo, 1969 (Figura 3 do presente), que não anota a ligação que, segundo defendemos, existiu anteriormente, desde o pouso (ponto 1) pela atual av. Júlio de Mesquita.

117.Atualmente, o trecho entre 14 e 17 denominase rua Irmãos Bierrembach.A afirmação de que o trecho 14-17 foi anteriormente parte da então rua Augusto César baseiase em planta de requerimento para ligação de água de 1927. Protocolo n 25729, de 31.3.1927, Arquivo Municipal.

118. Reynaldo Kuntz Busch, A História de L $i$ meira, cf. citação em $<$ http//: www.limeira.sp. gov.br>. Acesso em 28 jul. 2004. se chega pela atual avenida Brasil à "estrada do Matão", antigo acesso para Limeira, antes da abertura da rodovia Anhangüera.

O largo de Santa Cruz, onde houve o pouso em que Saint-Hilaire se abrigou em 1819, coloca-se em meio a esse caminho 1-13-14-19-20, entre os pontos 13 e 14. Com as reformulações do espaço desse largo (atual praça XV de Novembro, destacado em preto na fotografia 60), até à sua atual conformação retangular, é que teria sido interrompida a continuidade desse caminho pelas atuais avenidas Júlio de Mesquita e Brasil - quando, de resto, a origem dos fluxos em demanda da região de Limeira e Piracicaba já não seria o pouso das Campinas, mas sim a florescente vila de Campinas. Ou, por outra: o caminho 1-13-14-19, contínuo, teria sido interrompido entre os pontos 13 e 14, quando de uma reconformação da área do largo de Santa Cruz, num momento em que o caminho até a região de Limeira e Piracicaba, a partir da região de Campinas, não mais se daria a partir do pouso das Campinas (ponto 1), cruzando a atual praça XV de Novembro, mas sim a partir da vila de Campinas (ponto 12), chegando até o então largo de Santa Cruz, onde se podia seguir reto, em direção a Mogi, pela atual rua Major Sólon (17-18-5), ou dobrar à esquerda, em direção a Limeira ${ }^{116}$.

Pode apontar-se que a atual Júlio de Mesquita (1-13), quando, anteriormente a 1927, chamava-se "rua Augusto César", prolongava-se para além do ponto 13, até o ponto 17117. Já a atual avenida Brasil era um prolongamento da rua Santa Cruz, ainda em 1916 (como se vê na planta da cidade levantada naquele ano). Assim, a então rua Augusto Cezar (1-13-17) chegando a uma das laterais do retângulo da atual praça XV de Novembro - e parte da então rua de Santa Cruz (4-14) - na lateral oposta desse retângulo, e que se estendia pelo trecho atualmente denominado avenida Brasil (19-20) foram dois tramos descontínuos que, no início do século XX, correspondiam ao antigo percurso contínuo 1-13-14-19.

Não sabemos desde quando esse caminho 1-13 teria sido dado como trecho inicial de roła rumo à região de Limeira. Sabe-se que, em 1823, deu-se início à abertura de uma estrada de Campinas a Piracicaba, passando pelo engenho lbicaba, propriedade do Senador Vergueiro, no atual município de Limeira, sendo inaugurada três anos depois, em $1826^{118}$. É provável que, antes dessa nova estrada, já houvesse caminho naquela direção, partindo do pouso das Campinas.

Identificam-se na fotografia, portanto, cinco tramos distintos convergindo para o ponto 1 : dois que seriam o curso, a norte e a sul, da estrada dos Goiases (0-1 e 1-2), sendo os outros três justificáveis como ligações com os campinhos em derredor, bem como, respectivamente, com a sede da nova freguesia, com o bairro da ponte e com a região de Limeira e Piracicaba. A identificação desses tramos, e as indicações tendentes a firmá-los como caminhos existentes ainda antes da ereção da freguesia, concorrem decisivamente para corroborar a indicação de Pupo (1 969), que em seu croquis, sem haver indicado esses tramos, já localizava o pouso das campinas no cruzamento da avenida Moraes Sales com rua ltu, ponto 1 da fotografia 60. 
Oúltimo dos três caminhos - que, afora a própria estrada dos Goiases, convergem para o ponto 1 da fotografia 60 - ocupa o bordo oeste de um platô. Trata-se, aproximadamente, da área do polígono 1-13-4-3-2-1, entre o vale do Proença (no Leste) e o do Tanquinho (no Oeste), cujos cursos estão destacados na fotografia. No bordo oposto desse mesmo platô (no Leste), dá-se a seqüência da estrada dos Goiases, em boa parte pela atual rua Coronel Quirino.

Tendo atingido o pouso das Campinas, no ponto 1, a norma de que o caminho bandeirante seguisse pela crista do relevo permitiria supor quaisquer trajetos entre esses dois bordos - ou seja, entre as atuais avenida Júlio de Mesquita (1-13) e o trecho da rua Coronel Quirino (3-4). Entretanto, o registro de Daunt (1904) atesta, como já expusemos acima, ser a rua Coronel Quirino aquela que corresponde ao traçado da antiga estrada dos Goiases. Suplementarmente, citese ainda um manuscrito de memorialística urbana, parcialmente publicado quando falecido o autor, em 1904, na Revista do Centro de Ciências, Letras e Artes, n. 7, em que se lê: "Foi depois aberta a rua Coronel Quirino, em direcção á Santa Cruz; antes de ser aberta, existia uma estrada alli, antigamente"119, bem como na descrição de Daunt (1904), quando afirma que a estrada, passado o pouso, "tomava pelo caminho que corre em frente da chácara hoje [1879] do Dr. Sampaio Peixoto", o que se identifica como a atual Coronel Quirino, conforme já exposto acima.

Assim, a estrada dos Goiases seguiria, desde o pouso das Campinas, pelos pontos 2, 3, 4 e 5, da fotografia 60.

Entre 0 e 2 tem-se a atual rua ltu; de 3 a 4, o trecho da atual rua Coronel Quirino que teria sido parte da antiga estrada. Entre 2 e 3, o caminho, hoje, atravessa parte de uma quadra, podendo-se entretanto perceber, claramente, a continuidade do traçado entre a rua ltu e o referido trecho da rua Coronel Quirino ${ }^{120}$.

A partir do ponto 4, Pupo (Figura 3) faz seguir o caminho em direção à atual rua Santa Cruz; e, por essa, até as proximidades do largo de Santa Cruz (praça XV de Novembro), no ponto 18 da fotografia, de onde defletiria à direita, $90^{\circ}$, indo até o ponto 5 pela atual rua Major Sólon. No percurso entre 4 e 5 não vimos razão que justificasse esse desvio e o cotovelo de $90^{\circ}$ junto do largo de Santa Cruz. Tanto evidências documentais quanto uma razão lógica apontam, pelo contrário, ter o percurso original se dado de modo mais direto entre os pontos 4 e 5 , por traçado que contudo não nos foi possível determinar com maior precisão.

É certo que a rua Major Sólon, antiga da Ponte, foi caminho de saída para Mogi, desde a vila de São Carlos, futura cidade de Campinas ${ }^{121}$. Caminho tributário do desenvolvimento da Vila, em local, como já apontado, afastado do trajeto original da estrada bandeirista. É com o desenvolvimento da Vila, e a correlata consolidação do trajeto pela Major Sólon, que o percurso original desviase desde o ponto 4 até o largo de Santa Cruz. Nada do que conhecemos faz pensar que esse desvio tenha existido já em 1774, ou antes.

Salvo melhor interpretação do documento infra ou evidências em contrário, o desvio do percurso original, que deixa de ser feito diretamente do
119. Manuscrito de Custódio ManuelAlves, apud. Duarte (1904). Rafael Duarte não refere. a data do manuscrito, registrando entretanto que nascera "aos quatro dias do mez de março de 1835 ", e morrera "a 29 de janeiro do corrente anno [1904]". Ainda segundo o que se lê nessa mesma introdução, por Rafael Duarte, o manuscrito, de que ali se transcreve uma parte, teria sido doado ao acervo social do CCLA, onde buscamos o original desse documento, sem sucesso.

120. Ainda hoje, caminhando-se pela rua Itu em direção à rua Coronel Quirino, os edifícios verticais da quadra que se interpõe dispõem-se de tal maneira que é possível perceber essa continuidade.

121. Quando elevada a vila, a freguesia de Nossa Senhora da Conceição das Campinas do Mato Grosso ganhou o nome de São Carlos, voltando oficialmente a chamar-se Campinas quando da elevação a cidade, em 1842. 
122. Carta do Dr. Valentim José da Silveira Lopes Jr. à Câmara, 27.7.1881 (Arquivo da Câmara, cx 87).Ao final da carta, o Dr. Valentim pede que seja dado o nome de "Amador Bueno" à nova rua, pedido não acatado, deliberando a Câmara, em sessão de 1.8.1881, chamá la "Coronel Quirino".As atas da sessão de 13 de Julho de 1881, citada na car ta, pertencem a volume das atas que se encontra perdido (a sessão de 1. de agosto pertence ao volume seguinte, que pôde ser consultado)

123. "Emenda" com a antiga rua das Pingas, a essa época com curso mais restrito que a atual rua de Santa Cruz, sua sucedânea (GOULART, 1983). Quando a rua de Santa Cruz chamava-se rua das Pingas, esta seria um prolongamento de pouca extensão, a um canto do largo de Santa Cruz, espécie de pequena travessa com vendas ou botequins para os tropeiros. $\mathrm{O}$ mo mento flagrado é aquele em que esse beco é transformado mais propriamente em rua, com sua extensão e ligação até à rua Coronel Quirino. ponto 4 ao 5 para realizar-se através da rua de Santa Cruz, fazendo-se pelos pontos 4-18-5, passou a existir somente em 1881, quando da abertura da rua Coronel Quirino. Com efeito, na carta enviada à Câmara pelo Dr. Valentim José da Silveira Lopes Jr., médico da Santa Casa, datada de 27 de Junho de 1881 , dando conta da abertura da rua Coronel Quirino, lê-se:

Illmos. Snrs. / Communico a WSS que em vista da decisão tomada pela Illma Camara em sessão de 13 do corrente, acham-se por mim abertas ao transito publico as ruas que me propuz abrir atravez de meu terreno em Santa Cruz; sendo uma parte em continuação da rua que, começando na Rua Formoza [atual Conceição] segue até [palavra ilegível] ao meu terreno em linha recta, e outra parte fazendo ângulo com esta e que vai encontrar a de cima de Sta. Cruz [ou seja, a rua de cima da igreja de Santa Cruz], antiga das Pingas [atual rua de Santa Cruz]. Segundo o deferimento ao qual referi; vou tractar de feixar a parte da estrada velha, agora substituído, o que participo para os devidos effeitos ${ }^{122}$.

Dr. Valentim José da Silveira Lopes Jr. comunica ter aberto uma nova rua, sendo que uma parte vem, em linha reta, desde a atual Conceição até seus terrenos, onde ganha novo rumo, emendando "com a de cima de Santa Cruz" (de cima da igreja de Sta. Cruz), "antiga das Pingas"123. Ou seja, "abre-se" leia-se alarga-se e alinha-se - um trecho da antiga estrada (3-4 na fotografia) atual rua Coronel Quirino, entre Conceição e Guilherme da Silva -, desviandose a seguir o curso da antiga estrada pela atual rua de Santa Cruz. Trata-se precisamente da seqüência 3-4-18 da fotografia 60. $\bigcirc$ Dr. Valentim comunica, ainda, que irá tratar de "feixar a parte da estrada velha, agora substituido" na nossa leitura, o trecho 4-5.

Note-se ainda que a existência de um percurso original por 3-4-18 tornaria sem razão o trecho 1-2-3-4-18, posto que o trajeto poderia ser feito, nesse caso, mais diretamente por 1-13-18, caminho também existente. Sendo, entretanto, que a passagem por 3-4 (atual Coronel Quirino) tem sustentação na documentação, como já exposto, resta concluir que a seqüência se daria diretamente por 4-5, sem o desvio 4-18-5. A esse raciocínio lógico vem se somar a evidência documental supra, no sentido de que o desvio do caminho original 1-2-3-4-5 (que passa a ser 1-2-3-4-18-5, interditando-se o trecho 4-5) somente foi executado em 1881. Por essas razões, ao invés do traçado 1-2-3-4-18-5 (cf. PUPO, 1969), indicamos o traçado 1-2-3-4-5.

A topografia indica o ponto 5 como o de melhores condições para o transcurso do córrego de Anhumas, atual avenida Orozimbo Maia, concorrendo para o entendimento de que, já desde o traçado original (anteriormente à criação da freguesia), a estrada teria seguido por ali e pela atual rua Paula Bueno (de que 5-6, na fotografia 60 , é o trecho inicial). 
Reconstituição do traçado na área da fotografia 58

A partir do início da atual rua Paula Bueno, o traçado da estrada dos Goiases corresponderia, pouco mais ou menos, ao traçado da estrada de Mogi, claramente delineado nas fotografias de número 58 e 56 . O traçado dessa estrada aparece isolado já na fotografia 58, de 1940, quando a mancha urbana ainda não havia atingido a área aí coberta (Figura 14).

Tendo atingido a atual rua Paula Bueno (fotografia 60, ponto 5), o traçado da estrada dos Goiases seguiria por esta até o ponto 3, e daí pela então (1940) estrada de Mogi (3-4-5-6).

No ponto 4, atravessa-se o ribeirão Taquaral. A lagoa que se vê à esquerda, lagoa do Taquaral, atualmente pertencente a um parque público, não

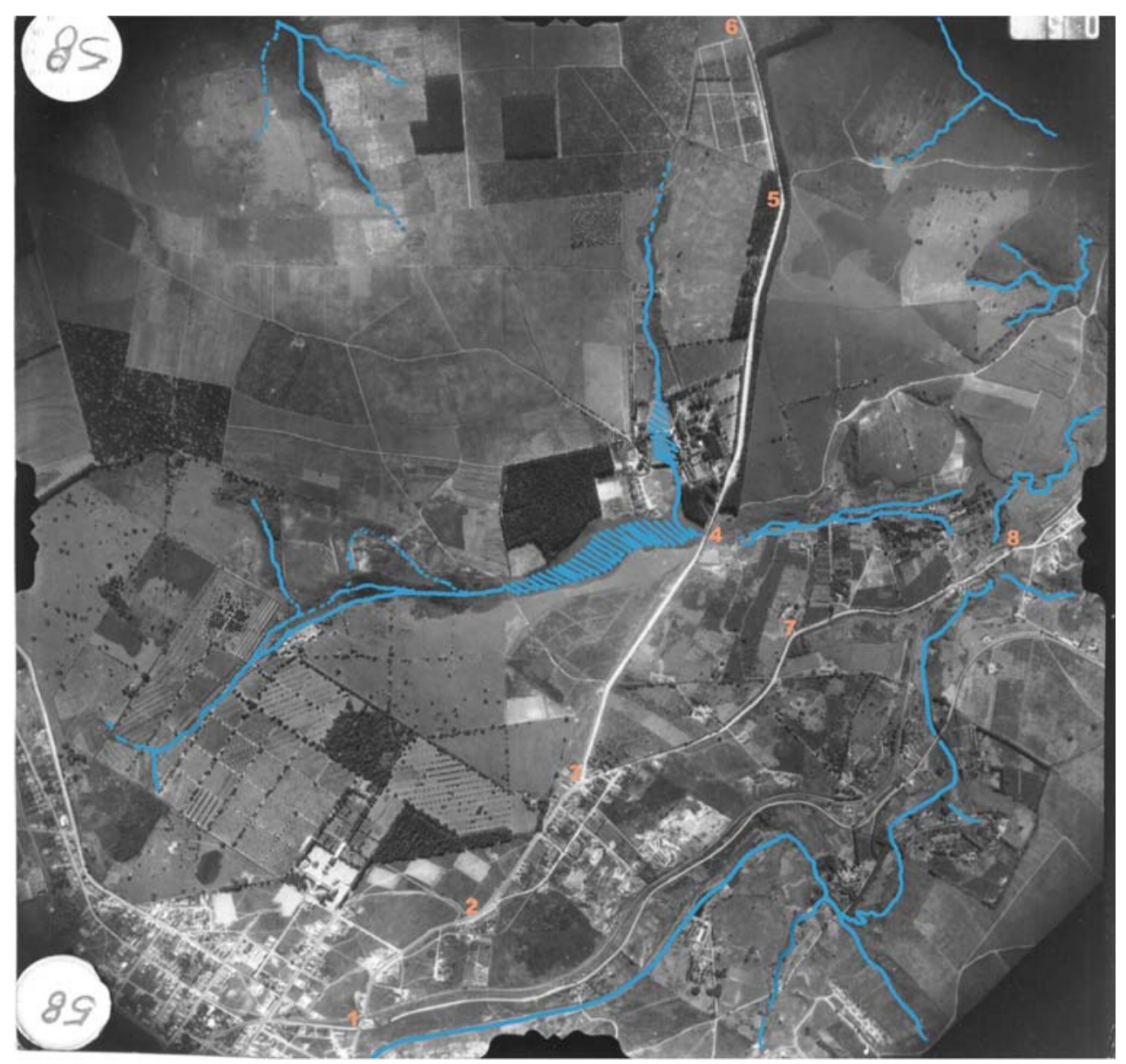

Figura 14 - Reconstituição, feita pelo autor, do traçado da estrada dos Goiases sobre a área da foto no 58 do levantamento aéreo de 1940. Ministério da Agricultura-Departamento Nacional de Produção Mineral, Levantamento aéreo de Campinas, 1940, chapa nº 58. Fotografia aérea, $18 \mathrm{~cm} \times 18 \mathrm{~cm}$. Fonte: Acervo digital do Departamento de Documentação, Informação e Cadastro - Secretaria de Planejamento - Prefeitura Municipal de Campinas. 
124. Não se encontrou referências à construção dessa barragem nos índices de Leis, Decretos e Resoluções do Municí pio, cuja edição contem pla o período desde 1890. É possível que essa barragem tenha sido uma obra particular, da então fazenda Taquaral. Por outro lado, colhemos depoimento de antigo morador da rua Paula Bueno; disse-nos que seu pai, então colono numa fazenda para os lados de Mogi, vinha a Campinas a pé, no iní cio do século, atravessando o ribeiro do Taquara por uma passagem por sobre a qual, pelo que entendemos, corria uma lâmina d'água; seria, portanto não uma ponte, mas uma barragem.

125. Nome oficial de Campinas, quando elevada a vila, em 1897, e até sua elevação a cidade, em 1842.

126. D'Alincourt (1975, p. 54$)$.

127. Do Barbosa, do Serafim, Anhumas. Anhumas foi denominação comum, dada a diferentes rios e ribeiros, na região.

128. A alternativa de traçado ocidental, na proposta de Costa Santos ( $\mathrm{Fi}$ gura 7), atende à passagem pela rua Barão de Jaguara, seguindo a descrição de d'Alincourt, descrição que Costa San tos (1998, p. 77) reproduz em nota. Porém desprezando a seqüência pe la atual Paula Bueno não atende à transposição do ribeiro Lava-pés nem do Taquaral, os quais d'Alincourt havia igualmente referido.

129. Pelo próprio relato de D'Alincourt, bastante pormenorizado, seria possível reconstituir o traçado por ele trilhado - além da descrição topo- é natural. O ponto de travessia corresponde a uma barragem, na fotografia. Não foi possível precisar a dała da construção dessa barragem; seria anterior a $1900^{124}$. O ponto de travessia da antiga estrada dos Goiases não seria muito diverso do ponto em que hoje está a barragem. Saindo de Campinas rumo a Mogi, D'Alincourt, em 1818 , registra que

[...] o rumo geral da estrada para a vila de Mugi-Mirim é Norte: ainda perto da Vila descese a um pequeno vale e atravessa-se o ribeiro Lapa-pés; a estrada vai seguindo em partes coberta de arvoredo, e noutras partes descoberta; e por ser o terreno algum tanto irregular, se encontram algumas pequenas subidas, e descidas. Meia légua distante de S. Carlos ${ }^{125}$ atravessa-se o ribeiro Taquaral e o caminho começa a descrever diversas curvas ${ }^{126}$.

O referido "Lapa-pés", num "pequeno vale", "ainda próximo à vila" não é outro senão o córrego da atual avenida Orozimbo Maia, para o qual temos visto diferentes denominações, na bibliografiaa ${ }^{127}$. A distância de meia légua até o ribeiro Taquaral (ponto 4) confere com a que se pode medir nas fotografias (escala 1:16 500|128. Causa estranheza apenas a referência a que, "atravessando-se o ribeiro do Taquaral o caminho começa a descrever diversas curvas", o que não confere com o traçado que vemos nas fotografias, não fazendo tampouco pensar num traçado mais antigo, a que viria a se sobrepor o da fotografia (estrada para Mogi, em 1940), dado que ali a topografia favorece um caminho reto, pela crista do relevo, contínua, a partir do ponto 4, e ao longo de toda a área da fotografia 56 que, por não trazer novidades, não reproduzimos em separado.

No ponto 3 vê-se que o caminho sofre uma bifurcação, notando-se que a derivação 3-7-8 apresenta-se em melhor solução de continuidade com relação ao anterior que a seqüência por 4-5-6. Essa seqüência por 7-8 era conhecida, no início do século XX, como "estrada para Anhumas". Dado que, pela alternativa por 4-5-6 (estrada de Mogi, em 1940), toma-se, já a partir de 4, um extenso espigão, rumo norte, ao passo que pela alternativa 7-8 desce-se logo a um vale, sem perspectiva de caminho melhor que o anterior para o Norte (rumo de Mogi), optamos pela hipótese de que o caminho dos Goiases tivesse seguido por aquele. Esse ponto, entretanto, ainda mereceria maiores pesquisas ${ }^{129}$.

\section{Conclusão}

A partir de foto-interpretação, realizada sobre levantamento aéreo de 1940, balizada por informes da historiografia local circunstancialmente sujeitos a verificação junto à documentação primária, reconstitui-se o traçado da antiga estrada dos Goiases na região da atual mancha urbana da cidade de Campinas.

A reconstituição mostra-se de acordo com o traçado esquemático apresentado por Celso Maria de Melo Pupo (1969, p. 47), contrariando tradição divergente que aponta passagem pelo vale do Proença latual avenida NorteSul), com destaque para a reconstituição apresentada por Santos (1998), em que todo o percurso no trecho em causa segue pelo dito vale (Figura 15). 


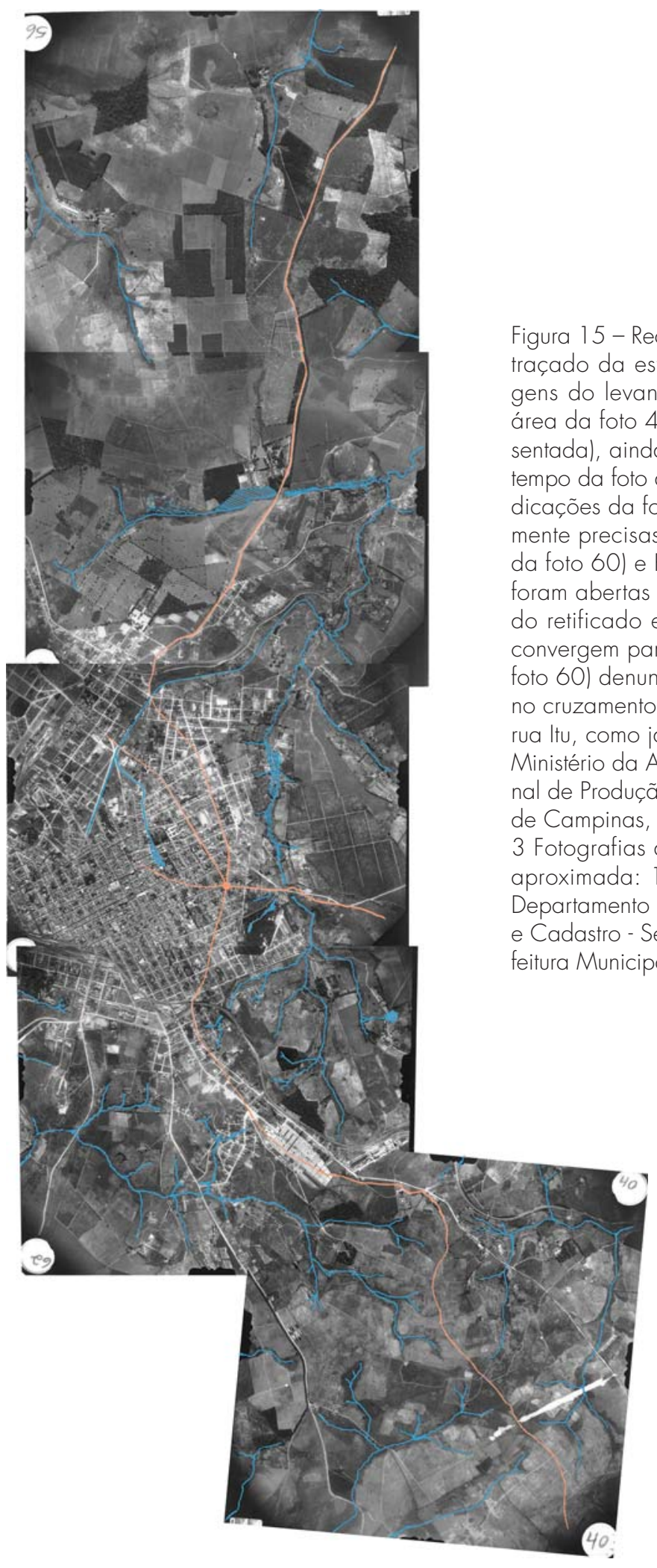

Annals of Museu Paulista.v. 14.n.2. July-Dec. 2006. 
gráfica, a partir da localização dos fazendeiros que vai arrolando. Uma tal reconstituição seria entretanto a do traçado em 1818.

130. Rua Cel. Rodovalho.
As razões do traçado proposto por Santos (1998) mereceram exame atento. Embora a reconstituição executada por esse autor para todo o trecho entre Jundiaí e Mogi tenha contado com recursos inéditos e ampla base documental, no trecho da atual mancha urbana a reconstituição baseia-se exclusivamente numa leitura do relato de Daunt (1904), tendo por pressuposto que as "Campinas Velhas" a que Daunt (1 904) se refere, e o pouso das campinas, coincidissem com o local de conhecida aguada, em fundo de vale, sob o atual viaduto Laurão, bem como que a frente da chácara de Sampaio Peixoto, igualmente referida por Daunt (1904), também se localizasse nesse mesmo fundo de vale. Mostrou-se, entretanto, que a afirmação de que o pouso se localizasse no fundo do vale, embora predominante na bibliografia, deriva de uma leitura possível, porém não necessariamente correta, que Bergó (1944) faz de passagem de Octavio (1922), sendo desde então reproduzida em outras obras. A localização correta, entretanto, é a proposta por Pupo (1969), justificada pelo curso geral da estrada e especialmente pela existência de diferentes tramos que convergem para esse ponto, identificados no presente trabalho. Quanto à frente da chácara de Sampaio Peixoto, demonstrou-se documentadamente que corresponde a trecho da atual Coronel Quirino. Corrigidos esses pressupostos, vê-se que a descrição de Daunt (1904) não se presta às conclusões de Santos (1998) e, pelo contrário, concorda com o traçado proposto por Pupo (1969) e pelo presente trabalho.

Sem prejuízo de o traçado proposto concordar, em sua quase totalidade, com o croquis de Pupo (1969), há divergências ou precisões tornadas possíveis pela foto-interpretação. Uma, que o beco do Rodovalho, ainda hoje existente ${ }^{130}$, fica dado como parte do caminho que ligava o pouso ao local do campinho e da igreja, atual praça Bento Quirino. Outra, que o caminho em seu traçado original não passava pelo atual Largo de Santa Cruz e rua Major Sólon, mas, desde a atual Coronel Quirino, seguia diretamente à atual Paula Bueno.

O fato de concordarem os traçados apresentados por Pupo (1969) e pelo presente trabalho, resultantes de métodos diversos - importando, naquele, a notória erudição do citado autor no que tange a documentos da história de Campinas e especialmente de seus primórdios, e, neste, as evidências hauridas da foto-interpretação -, concorre, por um lado, para sustentar o entendimento externado no croquis de Pupo, e, em sentido inverso, para validar os métodos empregados no presente trabalho, praticados e difundidos pelo prof. Dr. Gustavo Neves da Rocha Filho.

Tanto o traçado apresentado, acorde com as evidências da fotointerpretação e os documentos conhecidos, como a crítica do entendimento de que 0 trajeto tivesse seguido pelo vale do Proença importam para o estabelecimento de bases para a pesquisa das etapas seguintes do desenvolvimento da malha urbana daquela que foi, a seu tempo, a "Meca da República". 


\section{REFERÊNCIAS}

ALANIZ,Anna Gicelle García. Dr. Ricardo Gumbleton Daunt: o homem, o médico e a cidade (Campinas, 1843-1893).Tese (Doutorado História Social)-Faculdade de Filosofia, Letras e Ciências Humanas-Universidade de São Paulo, São Paulo, 1999.

AMARAL, Leopoldo. Campinas, recordações. São Paulo: Gráfica d'O Estado de S. Paulo, 1927.

BELLOTTO, Heloísa Liberalli. Autoridade e conflito no Brasil colonial: o governo do morgado de Mateus em São Paulo, 1765-1775. São Paulo: Conselho Estadual de Artes e Ciências HumanasSecretaria de Estado da Cultura, 1979.

BERGÓ, Maria Stela de Abreu. Estudo Geográfico da cidade de Campinas. In: CONGRESSO BRASILEIRO DE GEOGRAFIA, 10, 1944, Rio de Janeiro. Anais ..., v. 3. Rio de Janeiro: Conselho Nacional de Geografia, 1952. p. 641-694.

BITTENCOURT, Luiz Cláudio.Desenbo urbano de Campinas: implantação e evolução. Dissertação (Mestrado em História Social)-Faculdade de Filosofia, Letras e Ciências Humanas-Universidade de São Paulo, São Paulo, 1990.

BRITO, Jolumá.Tombamento de duas capelinhas de Souzas. Roteiro impresso de crônica radiofônica. 1980. Centro de Memória da Unicamp,Arquivo Jolumá Brito, pasta 123.

BUENO, Francisco de Assis Vieira. A cidade de São Paulo: recordações evocadas de memória, notas históricas. São Paulo:Academia Paulista de Letras, 1976 (Biblioteca da Academia Paulista de Letras, 2).

BURGER,A. Photographies aériennes et aménagement du territoire. Paris: Dunod, 1957.

CAMILLO, Ema E. R. Guia bistórico da nascente indústria em Campinas (1850-1887). Campinas: Mercado de Letras; Centro de Memória da Unicamp, 1998.

CAMPOS JUNIOR, Teodoro de Souza. História da fundação de Campinas (subsídios). In: IBGE. Monografia histórica do município de Campinas. Rio de Janeiro:Instituto Brasileiro de Geografia e Estatística, 1952.p. 5-187.

CAMPINAS, Câmara Municipal. Livro de Atas, 1881-1883. Campinas:Arquivo da Câmara Municipal de Campinas.

CAMPINAS, Prefeitura Municipal. Relatório dos trabalbos realizados pela Prefeitura durante o exercício de 1929... Campinas: Casa Genoud, 1930.

CAMPINAS, Tribunal de Justiça. Inventário de D. Maria Carolina da Silva Sampaio.Arquivo do Tribunal de Justiça de Campinas, $3^{\circ}$ ofício, cx. 356, processo n. ${ }^{\circ} 7400$. Campinas: Centro de Memória da Unicamp.

D'AlINCOURT, Luiz. Memória sobre a viagem do Porto de Santos à Cidade de Cuiabá. São Paulo: Itatiaia;Edusp, 1975. 
DAUNT, Ricardo Gumbleton. Reminiscencias do districto de Campinas em bairro, freguesia e villa. Revista do Centro de Ciências, Letras e Artes, Campinas, v. 3, n. 7, p. 122-134, 1904 (texto de 1879; primeira publicação, 1885).

DUARTE, Rafael deAndrade.Traços biographicos de Custodio ManoelAlves, com dous documentos sobre a topographia de Campinas. Revista do Centro de Ciências, Letras e Artes, Campinas, n. 7 , p. 135-144, 1904.

Campinas de outr'ora. São Paulo:Typographia Andrade \& Mello, 1905.

GOULART, Edmo. Campinas: ruas da época imperial. Campinas, Maranata, 1983.

GONÇALVES, Daniel Issa. O Peabirú: uma trilha indígena cruzando São Paulo. São Paulo: LAP, Faculdade de Arquitetura e Urbanismo-Universidade de São Paulo, 1998 (Cadernos de pesquisa do LAP, 24).

HOLANDA, Sérgio Buarque de.As Monções. In:TAUNAY,A. et al. Curso de Bandeirologia. São Paulo: Departamento Estadoal de Informações, 1941.

Monções. São Paulo: Brasiliense, 2000 (1. ${ }^{a}$ edição 1945).

HOMEM, Maria Cecília Naclério. O palacete paulistano e outras formas de morar da elite cafeeira: 1867-1918. São Paulo: Martins Fontes, 1996.

LAPA, José Roberto do Amaral. A cidade, os cantos e os antros: Campinas, 1850 a 1900. São Paulo: Edusp, 1996.

LEMOS, Carlos. Alvenaria Burguesa: breve história da arquitetura residencial de tijolos em $S$. Paulo a partir do ciclo econômico liderado pelo café. São Paulo: Nobel, 1989 (originalmente tese de livre-docência, FAU-USP, 1983).

LOPES JUNIOR, Francisco José da Silveira. Carta [à Câmara Municipal, datada de 27 jun. 1881 , sobre a abertura de rua no bairro de Santa Cruz (rua Cel. Quirino)]. Campinas:Arquivo da Câmara Municipal de Campinas, cx. 87, pasta 1881-II.

LORETTE,Antônio Carlos Rodrigues. Cemitérios em Campinas: a transformação do espaço para sepultamentos (1753-1881). Dissertação (Mestrado em Urbanismo) - Pontifícia Universidade Católica de Campinas, Campinas, 2003.

MENDES, José de Castro. Um pouso à beira da estrada. Correio Popular, Campinas, 27 jun. 1968. Suplemento especial História de Campinas 2, p. 3.

MOMBEIG, Pierre. Pioneiros e fazendeiros de São Paulo. São Paulo: Hucitec; Polis, 1984.

OCTAVIO, Benedicto. Campinas antiga - o fundador de Campinas. Revista do Centro de Ciências, Letras e Artes, Campinas, v. 6, n. 14, p. 27-32, 1907.

Campinas antiga - As mãos do enforcado. Revista do Centro de Ciências, Letras e Artes, Campinas, v. 7, n. 17, p. 21-29, 1908. 
PEREIRA, Paulo César Xavier. São Paulo: a construção da cidade (1872-1914). São Carlos: RIMa, 2004.

PUPO, Benedito Barbosa. Uma história: Campinas 1774. In: CAMPINAS, Prefeitura Municipal. Campinas 1774-1974. Campinas: Prefeitura Municipal de Campinas, [1974].

PUPO, Celso Maria de Mello. Campinas, seu berço e juventude. Campinas:Academia Campinense de Letras, 1969 (Publicações da Academia Campinense de Letras, 20).

ROCHA FILHO, Gustavo Neves da. Os caminbos quinbentistas de São Paulo. Original datilografado, 1994

ROSSETTO, Pedro Francisco. A cidade do curto século vinte: uma bistória social do advento e difusão do padrão de casa urbana isolada no lote em Campinas como história da síntese (1917-1927) de um novo padrão de cidade. Dissertação (mestrado em História e Fundamentos Sociais da Arquitetura e do Urbanismo) - Faculdade de Arquitetura e Urbanismo - Universidade de São Paulo, São Paulo, 2006.

SAINT-HILAIRE, Viagem à província de São Paulo. Belo Horizonte: Itatiaia; Edusp, 1975.

SANTOS,Antônio da Costa. Compra e venda de terra e água e um tombamento na primeira sesmaria da Freguesia de Nossa Senhora da Conceição das Campinas do Mato Grosso de Jundiaí.Tese (Doutorado em Arquitetura e Urbanismo) - Faculdade de Arquitetura e UrbanismoUniversidade de São Paulo, São Paulo, 1998.

SANTOS FILHO, Lycurgo de Castro. Campinas: evolução histórica. São Paulo: Atlântida, 1969 (Publicações da Academia Campinense de Letras, 19).

SÃO PAULO,Arquivo do Estado. Sesmarias. v. 2. São Paulo: Gráfica dos Tribunais, 1921.

SUSSMANN, Roberto. Fotografia aérea e urbanismo: notícia informativa para engenheiros e arquitetos. Belo Horizonte: Editora da Universidade Federal de Minas Gerais, 1961.

TAUNAY,Alfredo Maria Adriano d’Escragnolle (Visconde de). Marcha das Forças (expedição do Mato Grosso), 1865-1866: do Rio de Janeiro ao Coxim. São Paulo: Melhoramentos, [192?].

\section{FONTES}

Bibliotecas e Arquivos consultados

Arquivo do Estado de São Paulo.

Arquivos do Departamento de Documentação, Informação e Cadastro (DIDC), da Secretaria de Planejamento, Desenvolvimento e Meio-Ambiente da Prefeitura de Campinas.

Arquivo Municipal de Campinas (arquivo do executivo).

Arquivo da Câmara Municipal de Campinas (arquivo do legislativo). 
Arquivo do Tribunal de Justiça de Campinas (TJC), em comodato no Centro de Memória da Unicamp (CMU).

Arquivos e Biblioteca do Centro de Memória da Unicamp.

Centro de Documentação da Coordenadoria Setorial do Patrimônio Cultural (CSPC) da Secretaria de Cultura, Esportes e Turismo da Prefeitura Municipal de Campinas.

Biblioteca do Centro de Apoio à Pesquisa em História (CAPH), Faculdade de Filosofia, Letras e Ciências Humanas da USP (FFLCH-USP).

Biblioteca da Faculdade de Arquitetura e Urbanismo da Universidade de São Paulo (FAU-USP).

Biblioteca do Instituto de Filosofia e Ciências Humanas (IFCH) da Unicamp.

Biblioteca do Instituto Geográfico e Cartográfico (IGC).

Mapoteca da Biblioteca Pública Municipal "Mário de Andrade" da Secretaria da Cultura... da Prefeitura da Cidade de São Paulo.

\section{Cartografia e fotografias aéreas}

C. H. R., Carta Topografica da capitania de S. Paulo e seos certoens, emque sevê os descubertos, que lhe forão tomados por Minas Geraes, como também o caminbo que vai para Goias, $e$ R. ${ }^{\circ}$ Grande de S. Paulo do Sul com todos os seus pozos e pasagens. [177?]. Bico de pena sobre papel, 38 × $51 \mathrm{~cm}$. Mapa sem escala. Coleção Pirajá da Silva, Mapoteca da Biblioteca Municipal Mário de Andrade.

Carta de parte da diocese paulopolitana... [177?]. Bico de pena sobre papel , 48 x $59 \mathrm{~cm}$. Mapa sem escala. Coleção Pirajá da Silva, Mapoteca da Biblioteca Municipal Mário de Andrade.

PUCCI, Luiz. Planta da cidade de Campinas e seus edifícios principais, levantada em 1878 pelo engenheiro Luiz Pucci. 1878. Levantamento desenhado à mão, $63,5 \mathrm{~cm} \mathrm{x} 70 \mathrm{~cm} .1 \mathrm{mapa}$. Sem escala (No bordo inferior: "gravado por Fco. Lichtemberger: Lith. Travessa do Rosario, 21, S. Paulo - impresso por Julio Lacroix”). 1 fotocópia. Acervo do Centro de Documentação da Coordenadoria Setorial do Patrimônio Cultural - Secretaria da Cultura... - Prefeitura Municipal de Campinas; 1 cópia digital. Acervo digital do Departamento de Documentação, Informação e Cadastro - Secretaria de Planejamento - Prefeitura Municipal de Campinas.

Planta da cidade de Campinas: escala 1:4000. c. 1916. Levantamento desenhado à mão, 137 x $100 \mathrm{~cm}$. 1 fotocópia.Acervo do Centro de Documentação da Coordenadoria Setorial do Patrimônio Cultural - Secretaria da Cultura - Prefeitura Municipal de Campinas; 1 cópia digital.Acervo digital do Departamento de Documentação, Informação e Cadastro - Secretaria de Planejamento...Prefeitura Municipal de Campinas. (Pode-se datar essa planta de c. 1916, pois é a que serve de base à planta editada nesse ano pela Casa Genoud).

CASA GENOUD (Ed.). Planta da cidade de Campinas. 1916. Impresso em papel, $52 \mathrm{~cm} \mathrm{x} 45 \mathrm{~cm}$. 1 fotocópia.Acervo do Centro de Documentação da Coordenadoria Setorial do Patrimônio Cultural - Secretaria da Cultura... - Prefeitura Municipal de Campinas; 1 cópia digital.Acervo digital do Departamento de Documentação, Informação e Cadastro - Secretaria de Planejamento - Prefeitura Municipal de Campinas. 
VIEIRA,Jorge de Macedo.Planta cadastral de Campinas. 1929.Trabalho contratada pela Prefeitura aos engenheiros Jorge de Macedo Vieira e Carl Alexander Oelsner em 1927 e entregue em agosto de 1929. Compreende 27 pranchas em escala 1:1000, oito pranchas em escala 1:2000, uma planta geral em escala 1:5000 e uma planta da triangulação em escala 1:5000. Formato aproximado de cada prancha: $150 \times 130 \mathrm{~cm}$. Originais, desenhados sobre papel-coco (no bordo superior, abaixo do título, cada prancha traz manuscrito: "Campinas, 10 de agosto de 1929. / Jorge de Macedo Vieira”). Departamento de Documentação, Informação e Cadastro - Secretaria de Planejamento Prefeitura Municipal de Campinas.

MINISTÉRIO DA AGRICULTURA, Departamento Nacional de Produção Mineral. Levantamento aéreo da região de Campinas. 1940. fotografias p.b., $18 \mathrm{~cm} \mathrm{x} 18 \mathrm{~cm}$. (Cada fotografia apresenta, no verso, selo do Ministério da Agricultura. Datado de jun. 1940).118 imagens. Departamento de Documentação, Informação e Cadastro - Secretaria de Planejamento - Prefeitura Municipal de Campinas.

Artigo apresentado em 6/2005. Aprovado em 11/2006. 